University of Rhode Island

DigitalCommons@URI

Open Access Dissertations

2013

\title{
A COMPARISON OF CARBONIC ANHYDRASE AMONG INVERTEBRATES, WITH A FOCUS ON CEPHALOPODS
}

Albert C. Nyack

University of Rhode Island, alnyack@gmail.com

Follow this and additional works at: https://digitalcommons.uri.edu/oa_diss

\section{Recommended Citation}

Nyack, Albert C., "A COMPARISON OF CARBONIC ANHYDRASE AMONG INVERTEBRATES, WITH A FOCUS ON CEPHALOPODS" (2013). Open Access Dissertations. Paper 127.

https://digitalcommons.uri.edu/oa_diss/127

This Dissertation is brought to you for free and open access by DigitalCommons@URI. It has been accepted for inclusion in Open Access Dissertations by an authorized administrator of DigitalCommons@URI. For more information, please contact digitalcommons-group@uri.edu. 
A COMPARISON OF CARBONIC ANHYDRASE AMONG INVERTEBRATES, WITH A FOCUS ON CEPHALOPODS

BY

ALBERT C. NYACK

A DISSERTATION SUBMITTED IN PARTIAL FULFILLMENT OF THE REQUIREMENTS FOR THE DEGREE OF DOCTOR OF PHILOSOPHY

IN

BIOLOGY

UNIVERSITY OF RHODE ISLAND 


\title{
DOCTOR OF PHILOSOPHY DISSERTATION
}

OF

\author{
ALBERT C. NYACK
}

APPROVED:

Thesis Committee:

Major Professor

Brad A. Seibel

Raymond P. Henry

Marta Gomez-Chiarri

Nasser H. Zawia

DEAN OF THE GRADUATE SCHOOL

UNIVERSITY OF RHODE ISLAND

2013 


\begin{abstract}
Carbon dioxide $\left(\mathrm{CO}_{2}\right)$ is both an unavoidable waste product of aerobic carbohydrate metabolism and a fuel source for autotrophic and chemoautotrophic organisms. At biological $\mathrm{pH}, \mathrm{CO}_{2}$ rapidly reacts with interstitial and intracellular water to form carbonic acid $\left(\mathrm{H}_{2} \mathrm{CO}_{3}\right)$, that then dissociates into protons $\left(\mathrm{H}^{+}\right)$and bicarbonate $\left(\mathrm{HCO}_{3}{ }^{-}\right)$. While $\mathrm{CO}_{2}$ and $\mathrm{H}^{+}$readily diffuse across biological membranes, the majority of the $\mathrm{CO}_{2}$ in living tissues is in the membrane-impermeable form $\mathrm{HCO}_{3}{ }^{-}$. The enzyme carbonic anhydrase (CA) catalyzes the reversible hydration of $\mathrm{CO}_{2}$ with water to maintain an instantaneous equilibrium between these chemical species. CA is not only central to the transport and excretion of $\mathrm{CO}_{2}$ in animals (or uptake in autotrophic organisms), but is also indirectly involved in important physiological processes, such as osmoregulation and acid-base balance. The multiple functions of CA are a result of multiple isoforms that are localized to specific subcellular compartments/fractions. Furthermore, the level of CA activity in an organism can be induced to change in response to conditions in the ambient environment, and may also reflect the metabolic rate of the organism. This enzyme has been studied in cell and tissue types from numerous organisms, but has never been systematically characterized in squids. This dissertation examined CA activity in gill and mantle muscle among several cephalopod species in terms of aerobic mass-specific metabolic rates (MR), evolutionary relationships, and environmental conditions. It also compared the protein-specific activity of $\mathrm{CA}$ in the respiratory tissue reported in the literature for a broad array of invertebrates.
\end{abstract}


The CA activity in gill and mantle muscle tissue from three squid species was measured to examine whether differences in activity may be related to phylogenetic relationships or environmental adaptations. The three squid species, Dosidicus gigas, Lolliguncula brevis, and Doryteuthis pealeii have similar MR but endure different physiological demands due to their respective environmental conditions. The largest member of family Ommastrephidae, Dosidicus gigas, undergoes diel vertical migrations into a well-defined oxygen minimum zone in the eastern Pacific. The brief squid, Lolliguncula brevis, is the only squid species that inhabits the wide-ranging abiotic conditions of estuarine waters. This species is in the same family as Doryteuthis pealeii, yet the latter requires narrower environmental parameters. For all three species the total CA activity was greater in gill tissue than in mantle muscle, but the activity in each tissue was statistically the same between these species. The distribution of CA isozymes within the subcellular compartments, however, was more similar between $D$. gigas and $L$. brevis, species that chronically endure variable conditions, than between more closely related $L$. brevis and D. pealeii. Reflecting the similar MR of these three species, total CA activity in gill scaled independent of both mass and MR, however there was a significant relationship in mantle muscle. The findings suggest that while total CA activity is reflective of whole organism, environmental conditions seem to affect the subcellular distribution of this enzyme. Additionally, it appears that the primary function of CA in cephalopod gills is towards the removal of the large amounts of $\mathrm{CO}_{2}$ produced in these muscular, highly active animals. 
Broadening the comparison of CA activity among cephalopods, I examined the CA activity in gill and muscle tissue from cephalopod species at different depths to 1) further test the visual interaction hypothesis and 2) examine the relationship between CA activity and metabolic rate. The visual interactions hypothesis states that the decreasing metabolic rates with increasing depth distribution among visually-orienting oceanic species is due to relaxed selection for strong locomotory capacity because the diminished light levels result in less frequent predator-prey interactions. The CA activity in gills and gill mass each declined significantly with increasing depth. The protein concentration in both gill and mantle muscle also showed a significant decline with depth distribution. The CA activity in both gill and mantle muscle exhibited a strong, direct correlation with metabolic rates among cephalopods. These findings are in agreement with other studies that have tested the visual interactions hypothesis. Additionally, the activity of CA is clearly correlated with aerobic mass-specific metabolic rate among cephalopods.

To examine factors that affect CA activity once the influences of animal mass and metabolic rates are removed, I compared the protein-specific activity of CA in the respiratory tissues of 67 invertebrate species across four phyla. The data was obtained from published values of specific CA activity that met specific inclusion criteria. The specific CA activity values for all species sampled was analyzed in terms of taxonomic group, type of respiratory tissue, habitat, symbiotic relationships, and type of homogenate used in the assay. A subset of the data was utilized to examine residual correlations between specific CA activity and estimates of animal mass and metabolic rates. The weighted mean masses and metabolic rates within each family were 
calculated from values obtained through a second literature search. Using this truncated dataset only bivalves exhibited a correlation between specific CA activity and metabolic rate. The results suggest that, once difference in mass and MR are accounted for, the physiological demands placed on an organism to survive in a given habitat seem to be the driving factor underlying CA activity.

This work is the first to systematically analyze CA activity in cephalopods, and contributes to the growing body of knowledge about CA activity in invertebrate respiratory and muscle tissues. This research also broadens scientific understanding of the relationships between CA activity and whole animal metabolic rates, the impacts of an organism's environment, and differences among various invertebrate taxa. 


\section{ACKNOWLEDGEMENTS}

I would like to take this opportunity to dedicate this work to some important people in my life. To my daughter Caly, I never would have achieved this without your love. You inspired me to persevere through some really tough times more than you will ever know. A large part of my drive to complete this degree was to show you that you can accomplish anything you set your mind to. My grandfather, Ed Nyack, showed me that more can be conveyed in a single glance than in one thousand words. I miss you every day grandpa. To my fiancée Brooke Somers, I am ever so thankful that you found me, for always looking on the bright side, and being the repetitive 'you can do it' voice in my ear. Finally, Dorothy A. Cashdollar RN, my mother, is the strongest person I have ever known. I have no doubt that I never would have accomplished this milestone without her steadfast encouragement and tireless ear.

This research would not have been possible without the knowledge, guidance, and TREMENDOUS patience of my major advisor, Brad A. Seibel. He taught me how to be a better writer and critical thinker, and he honed my skills as a scientist. Thank you, Brad, for standing by me though some rough times, and for both pushing me and giving me latitude as the occasion required.

I would like to thank Ray Henry for offering to be on my committee, for his mentorship, and for lending his expertise throughout the course of this research. I am incredibly thankful for all of Marta Gomez-Chiarri's helpful advice, insight, and support. I am also grateful to Jackie Webb for her caring, straight-forward approach, constructive feedback, and keen attention to detail. Finally, my profound thanks to 
Candace Oviatt for her wisdom and offering perspectives that led me to consider both the historical and unique aspects of this research.

I would like to extend a huge thank you to my past and present lab mates Lloyd Trueblood, Amy Maas, Leanne Elder, Jillian Schneider, Abigail Bockus, Sara Marnell, and Rui Rosa. This work would not have been possible without their support and hours of stimulating conversation. A very special thank you to the many friends I have made along the way: Jason Ramsay, Jack and Stephanie Szczepanski, Christine Newton, Stephanie Guertin, Nicole Rohr, Courtney Schmidt, Mike Sipala, Emily Jones, Mike Budziszek, Matt Lotti, Amy Teodecki, Ashley Stoehr, Melissa Trueblood, and Gordon Ober You all helped me so much over the years, not the least of which was helping to maintain my sanity. I am eternally indebted to Anabela Maia, Jeff Overton and Stephanie Bush for their friendship and feedback on earlier drafts.

I am extremely grateful to the Biological Sciences department for all the support and opportunities throughout the years. I am especially thankful to Marian Goldsmith for always looking out for the best interests of the grad students, and for having the confidence in me to offer some unique experiences. Thanks to Evan Preisser for all the supportive conversations and providing the opportunities to contribute to the department's well being. I also would like to thank Chris Lane for offering his ultra-centrifuge and perseverance on an order that took two years to fulfill.

Finally, a warm thank you for all their love and encouragement I received over the years from my brother and sister-in-law, Ed and Cindy Nyack, and my sister Amy. You had confidence in me when I was filled with apprehension, and encouraged me to see this to the end. 


\section{PREFACE}

This dissertation is presented in manuscript format in accordance with the guidelines set forth by the Graduate School of the University of Rhode Island. Each chapter is written to stand alone as a separate research question while simultaneously contributing to the greater body of knowledge about cephalopod physiology and function of carbonic anhydrase in animals. Chapter 1 is in preparation for submission to Comparative Biochemistry and Physiology, Part B. Chapters 2 and 3 are currently in preparation for submission to Marine Biology. 


\section{TABLE OF CONTENTS}

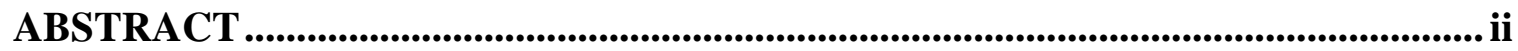

ACKNOWLEDGEMENTS ............................................................................. vi



TABLE OF CONTENTS................................................................................... ix

LIST OF TABLES …................................................................................................................ xi

LIST OF FIGURES ..........................................................................................

CHAPTER 1: Characterization of carbonic anhydrase activity from squid gills and mantle tissue ....................................................................................................................... 1

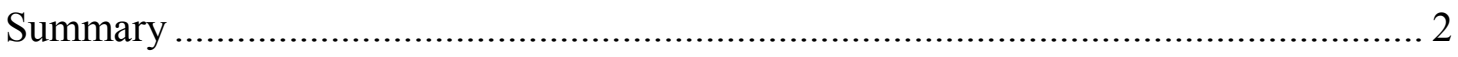

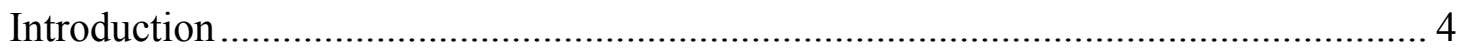



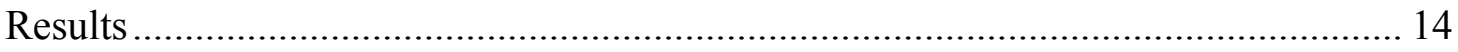

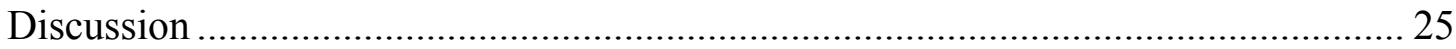

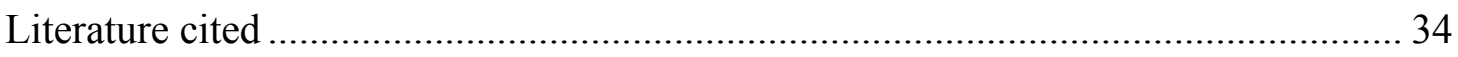

CHAPTER 2: Carbonic anhydrase activity in pelagic cephalopods from different depths ............................................................................................................................. 40

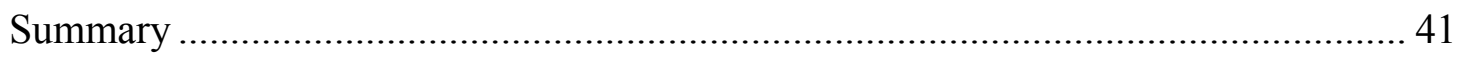

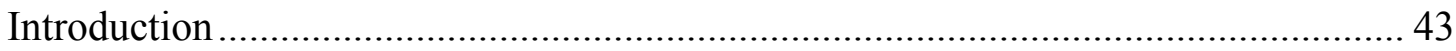





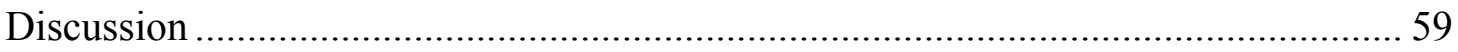

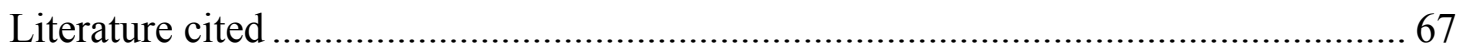


CHAPTER 3: Carbonic anhydrase in the respiratory tissue of invertebrates from four different phyla ......................................................................................................... 73

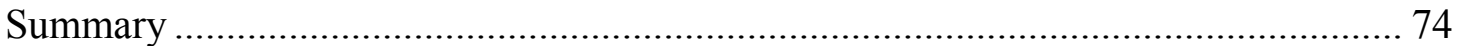

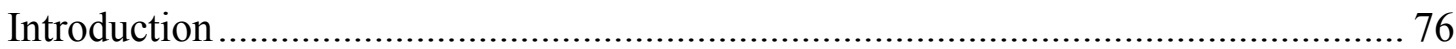



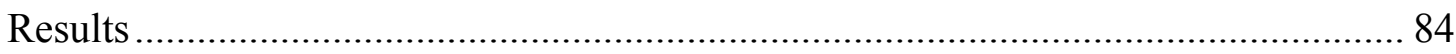

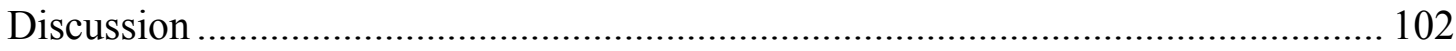

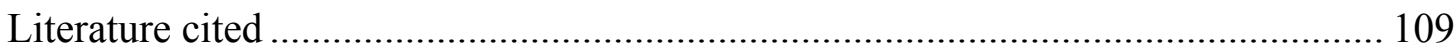




\section{LIST OF TABLES}

CHAPTER 1

TABLE

PAGE

Table 1. Morphometrics of squids used in the CA measurements and estimated temperature range at which specimens were caught

Table 2. Distribution of CA activity in gill and mantle tissue from segments of $D$. pealeii gill.

Table 3. The effect of washing on CA activity from initial pellets of cell debris and mitochondrial fractions (from Table 2)

Table 4. Inhibition constants (Ki) and enzyme concentrations (Eo) for CA from subcellular fractions

Table 5. Carbonic anhydrase subcellular activity $\left(\mu \mathrm{mol} \mathrm{CO} \cdot \mathrm{g}^{-1} \cdot \mathrm{min}^{-1}\right)$ as a function of squid mass $(\mathrm{M})$ and metabolic rate $\left(\mathrm{Mo}_{2}\right)$ in gill and muscle tissue....

\section{CHAPTER 2}

TABLE

Table 1. Depth, whole animal mass and range, [protein], and ecological some behavioral and physiological features of 11 species of cephalopods.

Table 2. Calculated mass-specific metabolic rates (MR), CA activity, and specific CA activity from gill and muscle tissue

\section{CHAPTER 3}

TABLE

Table 1. Specific CA activity ( $\mu \mathrm{mol} \mathrm{CO} 2 \mathrm{mg}$ prot $\mathrm{min}$ ) from published values averaged at each taxonomic level

Table 2. The taxonomic distribution of specific CA activity variance within each phyla. Values are percentages of total variance accounted for at successive taxonomic levels estimated from nested ANOVA.

Table 3. Weighted cumulative mean values for CA activity, mass, and metabolic rates. Cumulative measures were summed at the family level within each group 


\section{LIST OF FIGURES}

CHAPTER 1

FIGURE

PAGE

Figure 1. Representative plots of the CA assay in (A) gill and (B) muscle tissues from D. gigas

Figure 2. Mean total CA activity in gill (white) and mantle muscle (black) from three different squids.

Figure 3. Schematic depicting the separation of gill tissues into subcellular components by differential centrifugation

Figure 4. Intracellular fractional CA activity as a percent of the total activity in gill from three squid species

Figure 5. Schematic depicting the separation of mantle muscle tissues into subcellular components by differential centrifugation

Figure 6. Double reciprocal inhibitor titration plots of CA activity from D. gigas (A), L. brevis (B), and D. pealeii (C).

Figure 7. Carbonic anhydrase activity from crude homogenate as a function of squid mass $(A$ and $B)$ and estimate metabolic rate $(C$ and $D)$.

Figure 8. CA activity in the cytoplasmic fraction in gill (solid line) and mantle muscle (dashed line) in relation to squid mass (A) and mass-specific MR (B)

Figure 9. Schematic representation of distribution of intracellular CA isozymes and multiple physiological roles in $\mathrm{CO}_{2}$ and ammonia excretion and ion-exchange

\section{CHAPTER 2}

FIGURE

Figure 1. Representative profiles of oxygen concentration (solid lines) and temperature (dashed lines) as a function of depth, and the MDO of squids

Figure 2. Protein concentration ( $\mathrm{mg} / \mathrm{ml}$ tissue) as a function of minimum depth of occurrence (MDO)

Figure 3. Carbonic anhydrase activity measured in three $1-2 \mathrm{~cm}$ segments of gill tissue from D. pealeii (white) and M. magna (black).

Figure 4. Mean calculated mass-specific metabolic rate for each individual species...... 58

Figure 5. Carbonic anhydrase activity as a function of MDO for A) gill and B) muscle. 
Figure 6. Mean gill mass in relation to MDO of some representative squid species

CHAPTER 3

FIGURE

PAGE

Figure 1. The mean of reported CA specific activity in respiratory tissues reported in the literature normalized to $15^{\circ} \mathrm{C}$ grouped by phyla (A), all classes within the phyla (B), and by all orders within classes (C)

Figure 2. Mean CA specific activity among families of decapod crustaceans 86

Figure 3. The specific activity of CA between respiratory tissue types grouped by phyla.

Figure 4. Mean specific CA activity reported in respiratory tissues compared to organism habitat

Figure 5. Mean reported specific CA activity from respiratory tissue subcellular fractions grouped by class within their phyla 95

Figure 6. The specific activity of CA in gills of bivalves as a function of cumulative mean MR (A) and cumulative mean mass (B) .97

Figure 7. The specific CA activity among species of decapod crustaceans versus cumulative mean mass 98

Figure 8. The specific activity of CA in gills of decapods marine environment 


\title{
CHAPTER 1
}

\section{Characterization of carbonic anhydrase activity from squid gill and mantle tissue}

\author{
Albert C. Nyack ${ }^{1 *}$, Raymond P. Henry ${ }^{2}$, and Brad A. Seibel ${ }^{1}$ \\ ${ }^{1}$ Department of Biological Sciences, College of the Environmental and Life Sciences, \\ University of Rhode Island, 120 Flagg Road, Kingston, RI 02881-0816 \\ ${ }^{2}$ Department of Biological Sciences, Auburn University, 101 Rouse Life Science \\ Bldg., Auburn, AL 36849 \\ * Author for correspondence (email: nyackac@my.uri.edu)
}

In preparation for submission to:

The Journal of Comparative Biochemistry and Physiology 


\section{Summary}

The enzyme carbonic anhydrase (CA) rapidly catalyzes the interconversion of $\mathrm{CO}_{2}$ to $\mathrm{H}^{+}$and $\mathrm{HCO}_{3}{ }^{-}$and is central to the systemic transport and excretion of $\mathrm{CO}_{2}$. This reaction is also important in key physiological processes, such as acid-base balance and osmoregulation. Environmental changes (e.g. salinity) can induce changes in CA activity in gill tissue, and there is some evidence that CA activity is linked to metabolic rate. We measured $\mathrm{CA}$ activity in the gills and mantle muscle from Dosidicus gigas (Ommastrephidae), and two members of Loliginidae, Lolliguncula brevis and Doryteuthis pealeii. These squids exhibit similar mass-specific metabolic rates (MR), but have different size ranges and endure varied environmental conditions. We examined CA activity (total and within the subcellular fractions) in relation to aerobic metabolic demand, evolutionary relationships, and environmental factors. Total CA activity in gill tissue was around $8000 \mu \mathrm{mol} \mathrm{CO} \cdot \mathrm{g}^{-1} \cdot \mathrm{min}^{-1}$ for all species and was significantly greater than in mantle muscle. Within the subcellular fractions, over $75 \%$ of the CA activity in gill tissue from each species was attributable to cytoplasm and mitochondria combined. However, the subcellular distribution of CA activity was more similar in D. gigas and L. brevis, the two species that experience wide-ranging environmental parameters, than between the Loliginids. Total CA activity in gill tissue scaled independent of both animal mass and MR, whereas a significant scaling relationship was found between muscle CA activity and mass and MR. Among subcellular fractions, a significant scaling relationship was only detected in the cytosolic fraction, and occurred in both gill and muscle tissue. At first glance total CA activity appears to be related to metabolic rates in these species. However, examining 
$\mathrm{CA}$ in the subcellular compartments reveals that the distribution of CA in a tissue may be more related to environmental conditions than aerobic metabolic demands or phylogeny.

Key words: carbonic anhydrase, carbon dioxide, cephalopods, Dosidicus gigas, Doryteuthis pealeii, Lolliguncula brevis 


\section{Introduction}

Carbon dioxide $\left(\mathrm{CO}_{2}\right)$ is an unavoidable waste product of aerobic carbohydrate metabolism, and its production is directly proportional to metabolic rate. $\mathrm{CO}_{2}$ is highly soluble in water and spontaneously reacts with water in the cell cytoplasm and extracellular fluid of all living systems (reviewed for vertebrates by Walsh and Henry, 1991; Geers and Gros, 2000). This reaction forms carbonic acid that then dissociates into protons $\left(\mathrm{H}^{+}\right)$and bicarbonate $\left(\mathrm{HCO}_{3}^{-}\right)$(reaction 1, below). The rate constants for the forward and reverse reactions are different, with the hydration reaction being about 3 orders of magnitude faster than the dehydration reaction (Edsall, 1968). The pK of the $\mathrm{CO}_{2}$ system is 6.1 (DeJours, 1981), so that at physiological $\mathrm{pH}(7.4-8.0$ for terrestrial and aquatic species, respectively), over $95 \%$ of the total $\mathrm{CO}_{2}$ is in the form of $\mathrm{HCO}_{3}^{-}$. While $\mathrm{CO}_{2}$ is readily diffusible across biological membranes, $\mathrm{HCO}_{3}{ }^{-}$is not,

$$
\begin{gathered}
\mathrm{CO}_{2}+\mathrm{H}_{2} \mathrm{O} \leftrightarrow \mathrm{H}_{2} \mathrm{CO}_{3} \leftrightarrow \mathrm{H}^{+}+\mathrm{HCO}_{3}^{-} \\
\mathrm{CO}_{2}+\mathrm{H}_{2} \mathrm{O} \stackrel{\mathrm{CA}}{\leftrightarrow} \mathrm{H}^{+}+\mathrm{HCO}_{3}^{-}
\end{gathered}
$$

which can make $\mathrm{CO}_{2}$ elimination potentially problematic for metabolically active animals. The enzyme carbonic anhydrase (CA) rapidly catalyzes the reversible hydration of $\mathrm{CO}_{2}$ to $\mathrm{HCO}_{3}^{-}+\mathrm{H}^{+}$(reaction 2) at rates several orders of magnitude faster than the uncatalyzed reaction (e.g. Khalifah and Silverman, 1991). Originally discovered in mammalian erythrocytes (Meldrum and Roughton 1933a,b) the role of $\mathrm{CA}$ in $\mathrm{CO}_{2}$ transport and excretion has been well studied (Forster et al., 1980; Klocke, 1980; reviewed in Geers and Gros, 2000). The importance of erythrocyte CA is primarily in catalyzing the slow dehydration of $\mathrm{HCO}_{3}^{-}$in the pulmonary capillaries, 
where the residence time of blood is very short $(0.75 \mathrm{~s})$; this ensures that there will be a large enough $\mathrm{P}_{\mathrm{CO}_{2}}$ gradient across the lung (or gill) to drive $\mathrm{CO}_{2}$ excretion. When erythrocyte $\mathrm{CA}$ is inhibited, $\mathrm{CO}_{2}$ excretion is reduced, resulting in hypercapnia and acidosis in both terrestrial and aquatic species (e.g. Maren, 1967; Seibel and Walsh, 2001, 2003).

$\mathrm{CA}$ is also an important enzyme in several other key physiological processes. For example, the gills of aquatic organisms function in respiratory gas exchange, salt transport, and acid-base balance and CA can function in all three processes. The multiple functions of CA are a result of multiple isoforms that are localized to specific subcellular compartments/fractions within the gill. A membrane-associated CAIV is believed to function in the dehydration of extracellular $\mathrm{HCO}_{3}{ }^{-}$and thus facilitate $\mathrm{CO}_{2}$ branchial excretion (Henry, 1987; 1988a,b; Henry et al., 2003), and as such plays a similar role to CAIV in mammalian lungs (Klocke, 1980). Cytoplasmic CA (CAc) is believed to function in the intracellular hydration of respiratory $\mathrm{CO}_{2}$ to $\mathrm{H}^{+}$and $\mathrm{HCO}_{3}^{-}$, which are then used as counterions for general cation and anion transport, respectively, in the gills of both crustaceans and molluscs (Henry and Cameron, 1983; Henry and Saintsing, 1983; Henry, 1984, 2001; Henry et al., 2003). Because ion transport (specifically $\mathrm{Na}^{+} / \mathrm{H}^{+}$and $\mathrm{Cl}^{-} / \mathrm{HCO}_{3}{ }^{-}$exchange) has been linked to acid-base regulation (reviewed by Wheatly and Henry, 1992; Henry and Wheatly, 1992), cytoplasmic CA has been strongly implicated in this process as well. A mitochondrial isoform (CAV) has been documented for both lower vertebrate and invertebrate gills (Henry, 1988; Henry et al, 1988), but its function has not been systematically studied. 
One of the defining characteristics of branchial CA in euryhaline species is that enzyme activity is influenced by environmental salinity (Henry and Cameron, 1982a,b). In the blue crab, Callinectes sapidus, CA activity was significantly increased in the posterior gills during acclimation to low salinity (8\%o) (Henry and Cameron, 1982a), and this was found to be almost entirely due to increases in the cytoplasmic isoform (Henry, 1988). Furthermore, the increases in CA activity occur exclusively in the posterior gills in euryhaline crustaceans and correspond to the separation of respiratory vs. osmoregulatory function in anterior vs posterior gills (Henry and Cameron, 1982b; D'Orazio and Holliday, 1985; Castilho, et al., 2001; Serrano et al., 2007). The induction of CA activity in response to low environmental salinity is the best-documented case of this enzyme being affected by environmental factors in animals. In plants, especially algae such as Chlamydomonas (e.g., Coleman and Grossman, 1984), large increases in CA activity occur in response to low environmental $\mathrm{CO}_{2}$, suggesting that factors affecting metabolism may also alter $\mathrm{CA}$ activity. Similarly, some evidence suggests that CA activity may be reflective of metabolic demand in animals (Henry and Saintsing, 1983; Kochevar and Childress, 1996; Seibel and Walsh, 2001, 2003), but whether environmental factors (e.g. hypoxia), which alter metabolism, also affect levels of CA activity has not been systematically investigated.

Although CA has been investigated in several mollusks (Henry and Staintsing, 1983; Kochevar and Childress, 1996; Baillie and Yellowlees, 1998; David et al., 2005; Yu et al., 2006), including the cuttlefish Sepia officinalis (Addink, 1971; Donaubauer and Schipp, 1978; Shipp et al., 1979), its distribution, characterization, and 
physiological roles in squids have never been assessed. This is surprising since squids remain model organisms for many anatomical, visual, neurological, and physiological studies (Sweeny et al., 2007; Castillo et al., 2011; Rosa and Seibel, 2008). Squids are widely distributed in the marine environment and are variable in size and metabolic rates (MR) (Hendrix et al., 1981; Nesis, 1983; Hanlon and Messenger, 1996; Seibel et al., 1997). Once temperature and body mass are accounted for, some species in the families Ommastrephidae and Loliginidae (two families characterized as highlymuscular, active swimmers) exhibit the highest aerobic MRs among organisms (Seibel, 2007). Although members of these families exhibit similar MR, some species (e.g., Dosidicus gigas and Lolliguncula brevis) are each adapted to widely varying oxygen levels and salinities that would exert chronic stress and constraints on the physiological processes in which CA is involved.

The Humboldt squid, Dosidicus gigas, is the largest Ommastrephid, attaining sizes of $>1 \mathrm{~m}$ mantle length (ML) and masses up to $50 \mathrm{~kg}$ (Nesis, 1983, Markaida et al., 2004). Its horizontal distribution extends throughout the eastern tropical Pacific from $\sim 45^{\circ} \mathrm{S}-40^{\circ} \mathrm{N}$ and westward along the equator to $140^{\circ} \mathrm{W}$ (Nesis, 1983; Nigmatullin et al., 2001). This range overlaps an extensive, and well-established, oxygen minimum layer (OML) that exists $200-1000 \mathrm{~m}$ in depth in the eastern tropical Pacific (Fiedler and Talley, 2006; Fabry et al., 2008). Adult D. gigas undergo diel vertical migrations during which they are found within the warm, well-oxygenated surface waters at night $\left(0-200 \mathrm{~m}, \sim 30^{\circ} \mathrm{C}\right)$ and within the $\mathrm{OML}\left(<0.1 \mu \mathrm{M} \mathrm{O}_{2} \bullet \mathrm{L}^{-1}\right.$, $300-1000 \mathrm{~m},<10^{\circ} \mathrm{C}$ ) for prolonged periods during the day (Gilly et al., 2006). Thus, both the horizontal and vertical distributions of $D$. gigas coincide with the OML 
(Nigmatullin et al., 2001; Gilly et al., 2006; Rosa and Seibel, 2008,). Some of the compensatory strategies enabling D. gigas to endure prolonged residence in the $\mathrm{OMZ}$ are beginning to be elucidated. Recent findings suggest that a combination of metabolic suppression and strong oxygen affinity by hemocyanin play prominent roles (Rosa and Seibel, 2008, 2010; Seibel, 2013).

The brief squid, Lolliguncula brevis (Loliginidae) also tolerates broad ranges of salinity, temperature, and oxygen concentration (Hendrix et al., 1981; Vecchione, 1991; Bartol et al., 2002). Within the Chesapeake Bay, L. brevis has been routinely found in wide-ranging bottom temperatures $\left(8-30{ }^{\circ} \mathrm{C}\right), \mathrm{O}_{2}$ concentrations $(59.4-$ $456.54 \mu \mathrm{M} \mathrm{O}_{2} \cdot \mathrm{L}^{-1}$ ), and salinities $(18-35 \mathrm{ppt})$ from spring until late fall (Bartol et al., 2002). This species is the only squid species found in estuarine waters (Hendrix et al., 1981; Vecchione, 1991; Bartol et al., 2002). However, the adaptations that enable L. brevis to thrive in broad thermal, haline, and oxygen conditions remain unclear.

In contrast to the previous two species, the conditions experienced by the longfin squid, Doryteuthis pealeii (Loliginidae), are comparatively narrower, and its distribution appears to be more temperature dependent (Dawe et al., 2007). This species migrates seasonally from inshore waters in the summer $\left(13-20^{\circ} \mathrm{C}\right.$, surface 200m) (Broaziak and Hendrickson, 1999) to offshore from Georges Bank to Cape Hatteras in winter $\left(9-12^{\circ} \mathrm{C}, 100-200 \mathrm{~m}\right)$ (Roper and Young, 1975; Roper et al., 1984). D. pealeii is distributed in comparatively stenohaline, stenothermal, and welloxygenated conditions in that are generally representative of most Loliginids.

The physiological adaptations that enable $D$. gigas and L. brevis to endure 'extreme' environmental conditions suggests different osmoregulatory and acid-base 
balance demands on these species compared to those experienced by $D$. pealeii. The central role of $\mathrm{CA}$ in $\mathrm{CO}_{2}$ excretion and osmoregulation made it a logical choice to examine among these squids with similar MR but distinct environmental adaptations. The goal of this study was to determine the extent to which CA activity is related to aerobic metabolic demand, evolutionary relationships, ambient environmental factors, or a combination of these factors. This study measured differences in total CA activity between mantle muscle and gill tissues (the predominant sites of $\mathrm{CO}_{2}$ production and excretion, respectively) in the three squid species described above. We also characterized CA activity among intracellular pools (mitochondrial, microsomal, and cytoplasmic) in gill and mantle muscle. We examined fractional CA activity along the length of $D$. pealeii gills to test the hypothesis that activity differs between anterior and posterior gill lamellae based on putative differences in physiological function (respiratory vs. osmoregulatory) (Shipp et al., 1979). Lastly, we examined scaling relationships between CA activity and animal mass and metabolic rates.

\section{Methods}

Animal collection

Doryteuthis pealeii were caught in Narragansett Bay, RI between April - June and in September of 2008 and May - June, 2009 via either otter trawl aboard the Captain Bert (URI) or fished using Japanese style jigs off Goat Island Bridge Newport, RI. Additional D. pealeii were caught aboard Project Oceanology vessels (UConn, Avery Point campus) using an otter trawl near New London, CT from May - 
June, 2009. Squid were either dissected immediately or held in coolers or troughs with continuously flowing seawater until dissection.

Lolliguncula brevis were caught via otter trawl in Nickawampus Creek and/or Main Channel creek near Virginia Institute of Marine Science Eastern Shore Laboratory, Wachapreague, VA in September 2008 and November 2009. Squid were maintained in aerated coolers until dissection. The seawater in the coolers was frequently refreshed en route to VIMS' lab.

Dosidicus gigas were fished at night using jigs in waters over Guaymas Basin in the Sea of Cortez, Mexico, aboard the R/V New Horizon from May-June 2009 and again in 2010. Each specimen was dissected immediately upon landing and tissue samples were flash frozen in liquid nitrogen before being stored at $-80^{\circ} \mathrm{C}$ until use.

For all specimens, whole animal mass, mantle length, and mantle thickness, and gender (when possible) were obtained from each specimen prior to tissue sampling.

\section{Tissue collection}

The mantle cavity was accessed by a sagittal incision along the length of the ventral mantle surface. The entire gill distal from the branchial heart in L. brevis and the anterior $1-2 \mathrm{~cm}$ of gill from $D$. gigas were excised. In the case of D. pealeii 2-3 sections of gill tissue were excised, depending upon the length of the gill. These sections were categorized as: anterior gill (the first $1 \mathrm{~cm}$ from the anterior tip), posterior gill (the first $1 \mathrm{~cm}$ distal from the branchial heart), and middle gill $( \pm 0.5 \mathrm{~cm}$ from the center of the gill). Thin, rectangular slices of mantle tissue approximately 
$3 \mathrm{~mm} \times 10-15 \mathrm{~mm}$ were excised from the anterior edge of the mantle in all species. Blood samples were also obtained from either the branchial heart or head sinus using a 27 gauge needle. All samples were immediately placed into cryo-vials and frozen in liquid nitrogen before being stored at $-80^{\circ} \mathrm{C}$ until use.

\section{CA assays}

Carbonic anhydrase activity was determined in both whole tissue homogenate and sub-cellular fractions using the $\Delta \mathrm{pH}$ method (Henry, 1991a). Frozen tissues were homogenized on ice using glass homogenizers (Kotex, Fisher Scientific) diluted in 319 volumes of assay buffer (in mM: 125 mannitol, 75 sucrose, 10 Tris-base, $\mathrm{pH}=7.4$ ) depending on the mass and tissue type, with mantle typically requiring greater dilution. Prior to centrifugation, an aliquot of crude homogenate was removed to measure total $\mathrm{CA}$ activity. The remaining homogenate underwent differential centrifugation to separate intracellular compartments (modified from Henry, 1991b). Crude homogenate was centrifuged $270 \times \mathrm{g}$ for $15 \mathrm{~min}$ at $4{ }^{\circ} \mathrm{C}$ to pellet unbroken cells, nuclei, and large cell fragments (p1). The supernatant was then spun at 7,500 x $g$ for 20 min at $4{ }^{\circ} \mathrm{C}$ to pellet mitochondria (p2). Approximately $300-500 \mu 1$ of the remaining supernatant was diluted 5-50x in assay buffer centrifuged at 100,000 $\mathrm{x} g$ for 90 min at $10{ }^{\circ} \mathrm{C}$ to pellet microsomes (p3) and leave the cytoplasm (s3) in the final supernatant. Pellets were resuspended in 4-29 volumes of assay buffer and placed on ice until use. After measuring initial activity, the $\mathrm{p} 1$ and $\mathrm{p} 2$ suspensions from gill sections of $D$. pealeii were each centrifuged as before. Supernatants were saved and 
pellets were resuspended in 4-9 volumes of assay buffer. Both supernatants and pellets of each fraction were assayed and the percent of initial activity calculated.

Samples were assayed in a water-jacketed reaction chamber (Radnoti Glass, Monrovia, CA) at $4{ }^{\circ} \mathrm{C}$ that contained $4 \mathrm{ml}$ assay buffer under constant stirring. The buffering capacity of the assay buffer was determined by the addition of $80 \mu 1$ of 0.1 $\mathrm{M} \mathrm{HCl}$ and deemed acceptable if the average $\Delta \mathrm{mV}$ of three assays conducted over two minutes was $30-40 \mathrm{mV}$. Representative plots of gill and muscle assays, and the effect of $100 \mu \mathrm{M}$ acetazolamide (Az), described as follows are shown in Fig. 1. The uncatalyzed reaction was initiated by the addition of $80 \mu 1 \mathrm{CO}_{2}$-saturated DI $\left(\mathrm{CO}_{2}\right.$-DI). The $\Delta \mathrm{pH}$ was measured using a Red Rod $\mathrm{pH}$ electrode (Radiometer Analytical) connected to an Orion $720 \mathrm{~A}^{+}$(Fisher Scientific) meter. The meter relayed the $\mathrm{pH}$ and $\mathrm{mV}$ data to a laptop computer every five sec over a two minute period. Catalyzed reactions were performed in triplicate with the addition of 2.5-10 $\mu 1$ of sample. The average variation between the triplicates was less than $10 \%$. Between assays, the $\mathrm{pH}$ electrode was rinsed with deionized water (DI) and stored at $4{ }^{\circ} \mathrm{C}$ in an adjacent water-jacketed reaction well containing assay buffer.

The rates of the catalyzed and uncatalyzed reactions were determined from the initial slope of the reaction; the rate of the uncatalyzed reaction was subtracted from the mean of the three catalyzed rates. The buffering capacity and proton content of $0.1 \mathrm{M} \mathrm{HCl}$ were then used in the calculation to convert this net rate $(\mathrm{mV} / \mathrm{min})$ to the rate of $\mathrm{CA}$ in terms of $\mathrm{CO}_{2}$ converted per minute per gram tissue.

Carbonic anhydrase activity in the mitochondrial, microsomal, and cytoplasmic fractions was also titrated with serial concentrations $(0.625-25 \mathrm{nM}$ final 


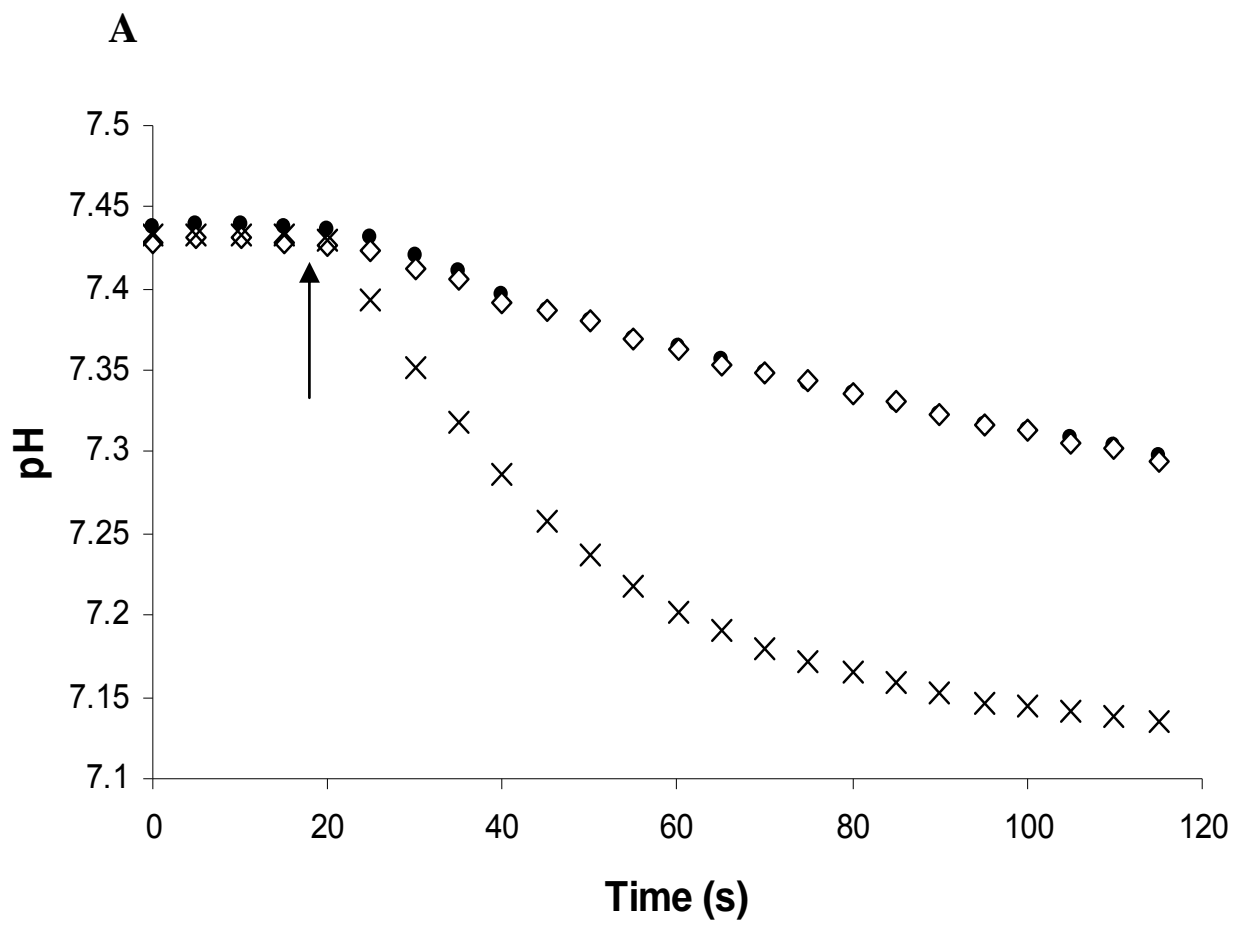

B

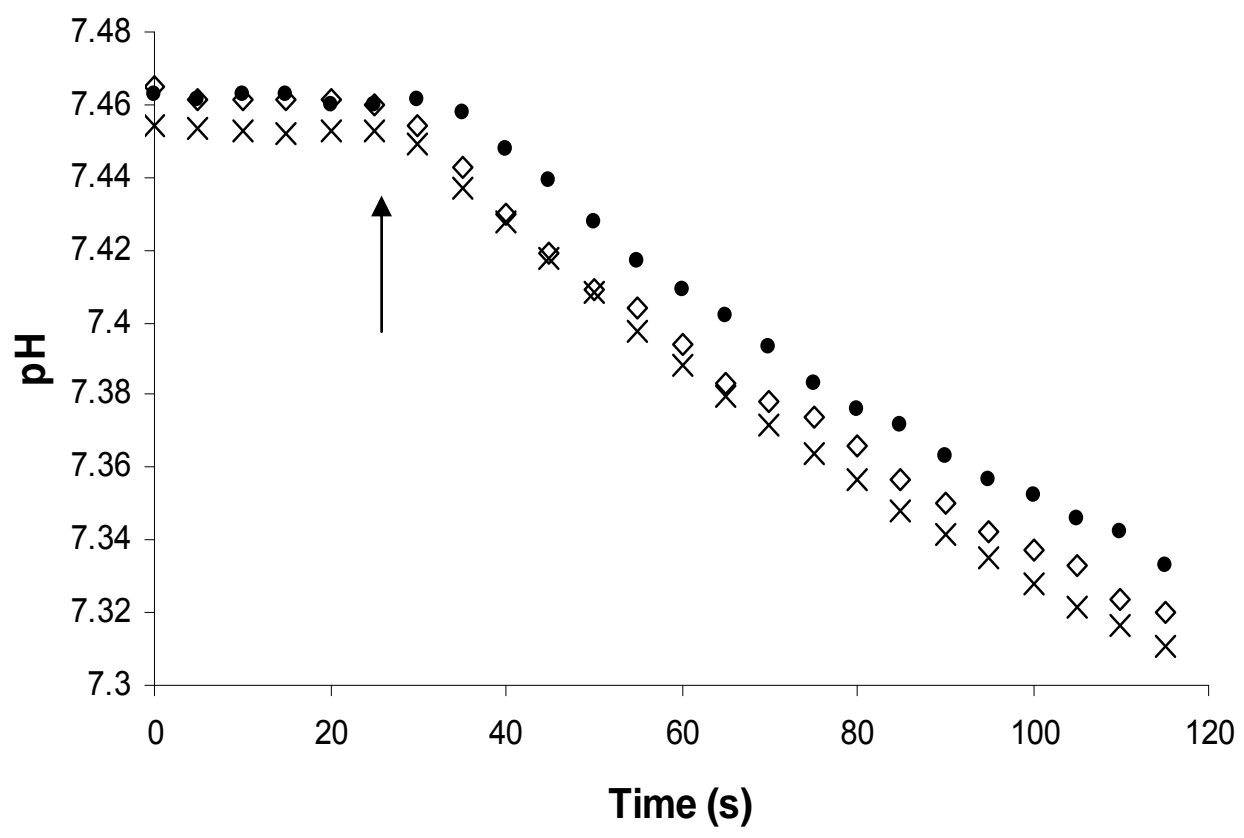

Figure 1. Representative plots of the CA assay in (A) gill and (B) muscle tissues from $D$. gigas. The arrows denote the approximate points at which $\mathrm{CO}_{2}$-saturated DI water was injected to initiate each reaction. Note the difference in scale on the $\mathrm{y}$-axis resulting in the appearance that the uncatalyzed and acetazolamide (Az) reactions are steeper in (B). Symbols represent the mean catalyzed (x), uncatalyzed $(\bullet)$, and assays containing both tissue and $100 \mu \mathrm{M}(25 \mathrm{nM}$ final concentration) of the CA inhibitor, Az $(\diamond)$. 
concentration) of Az. The data were plotted according to the formula described be Easson and Stedman (1937):

$$
\mathrm{Io} / \mathrm{i}=\mathrm{Ki} /(1-\mathrm{i})+\mathrm{Eo}
$$

where Io is the inhibitor concentration, $\mathrm{i}$ is the fractional inhibition at a given Io, $\mathrm{Ki}$ is the inhibition constant, and Eo is the total concentration of enzyme. These plots allow estimates of inhibition constants and enzyme concentrations for each fraction. Inhibition assays were performed in duplicate for 2-5 subcellular fractions from each species.

\section{Statistics}

Analysis of variance (ANOVA; $\alpha=0.05$ ) was used to compare total CA activity between gill and muscle tissue within each species, and for each tissue between species. An ANOVA was also used to test for differences in CA activity between intracellular fractions of a given tissue within each species. A two-way ANOVA was used to test for effects of species and activity in intracellular fractions. Where significance was detected, Tukey-Kramer HSD was used for pair-wise comparisons. All analyses used JMP software version 10 (SAS Institute, Carey, NC).

\section{Results}

The overall mean body masses for squids used in CA assays are shown in Table 1 . The mean body mass of species used to examine gill CA activity spanned nearly two orders of magnitude. There was approximately a 43 -fold difference in body mass between $L$. brevis and D. gigas sampled for CA measurements in mantle muscle 
(Table 1). The effect of seasonal and catch year on CA activity for each species were tested and were not significantly different (data not shown).

Table 1. Morphometrics of squids used in the CA measurements and estimated temperature range at which specimens were caught. Values are means \pm SEM.

\begin{tabular}{|c|c|c|c|c|c|}
\hline & \multicolumn{2}{|c|}{ Gill } & \multicolumn{2}{|c|}{ Mantle Muscle } & \multirow[t]{2}{*}{$\begin{array}{c}\text { Temperature } \\
\text { range }\left({ }^{\circ} \mathrm{C}\right)\end{array}$} \\
\hline & $\begin{array}{c}\text { Mean } \\
\text { mantle } \\
\text { length }(\mathrm{cm}) \\
\end{array}$ & $\begin{array}{c}\text { Mean mass } \\
(\mathrm{g})\end{array}$ & $\begin{array}{l}\text { Mean mantle } \\
\text { length }(\mathrm{cm})\end{array}$ & $\begin{array}{c}\text { Mean mass } \\
(\mathrm{g})\end{array}$ & \\
\hline D. gigas & $22.40 \pm 1.17$ & $300.0 \pm 31.6$ & $22.63 \pm 1.48$ & $300.0 \pm 40.8$ & 29 \\
\hline D. pealeii & $10.92 \pm 1.17$ & $41.72 \pm 7.77$ & $13.32 \pm 2.02$ & $45.04 \pm 6.59$ & 20 \\
\hline L. brevis & $3.30 \pm 0.28$ & $3.1 \pm 0.7$ & $3.96 \pm 0.74$ & $7.07 \pm 3.91$ & $15-25$ \\
\hline
\end{tabular}

\section{Total CA activity}

Total CA activity (crude homogenate) in gills (approximately $8000 \mu \mathrm{mol}$ $\mathrm{CO}_{2} \cdot \min ^{-1} \cdot \mathrm{g}^{-1}$ for all three species) was significantly greater $(\mathrm{p}<0.0001)$ than in muscle $\left(200 \mu \mathrm{mol} \mathrm{CO} \cdot \mathrm{min}^{-1} \cdot \mathrm{g}^{-1}\right.$ in D. pealeii and D. gigas, and $700 \mu \mathrm{mol} \mathrm{CO}{ }_{2} \cdot \mathrm{min}^{-1} \cdot \mathrm{g}^{-}$ ${ }^{1}$ in L. brevis) respective to each species (Fig. 2). Total muscle CA activity in each

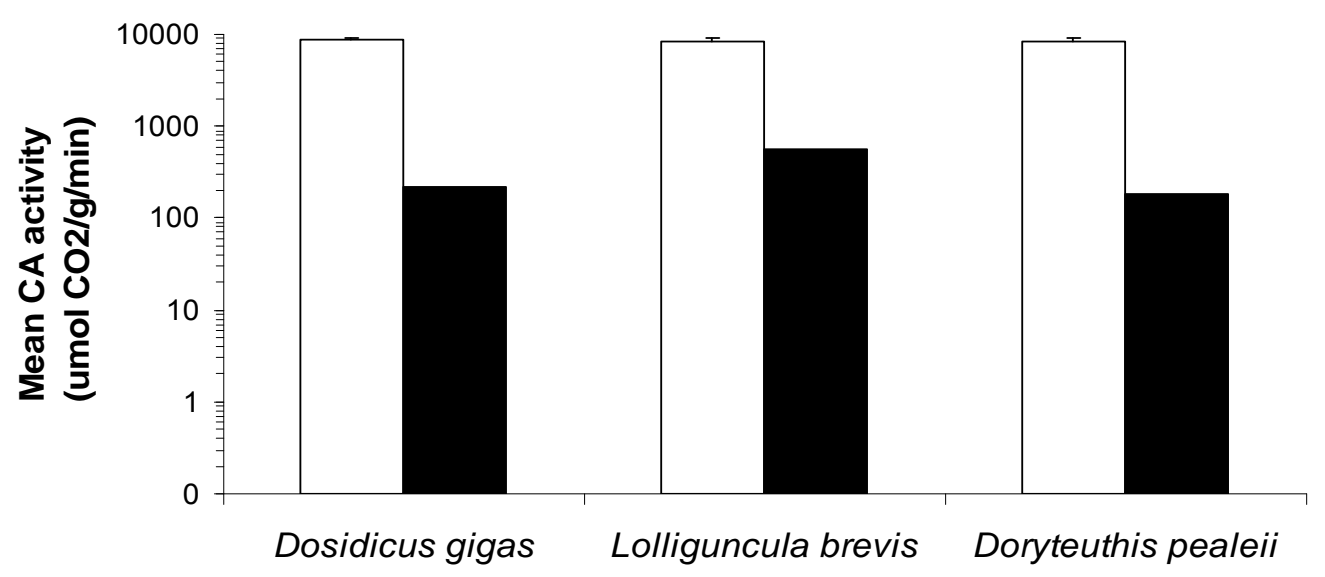

Figure 2. Mean total CA activity in gill (white) and mantle muscle (black) from three different squids. For each species, gill CA activity was significantly greater than mantle muscle $(\mathrm{p}<0.0001)$. However, for each tissue there was no difference in CA activity between each species. CA activity was plotted on a log scale for improved visualization of muscle activity. Error bars appear absent due to y-axis scaling. Values are means \pm SEM. 
species represented only $2.5 \%, 2.3 \%$, and $8.6 \%$ of the activity measured in gill for $D$. gigas, D. pealeii, and L. brevis, respectively. There was no significant difference, however, in the total CA activity of either tissue when compared among the three species (Fig. 2). There was also no activity found in hemolymph of any species (data not shown).

\section{Intracellular fractional CA activity within and between species}

Although the total CA activity among the gills was similar in all three squid species, the intracellular distribution of CA revealed notable differences between them. Among the intracellular fractions, the vast majority of CA activity was found in the cytoplasm (s3) and mitochondria (p2), with much less in the cell debris (p1) and microsomes (p3). The $\mathrm{p} 2$ fraction in gill of $D$. gigas had a significantly greater activity than any other fraction in that species $(\mathrm{P}=0.0121$; Fig. 3$)$. This fraction was also approximately double the activity in the $\mathrm{p} 2$ fraction from $D$. pealeii or L. brevis $(\mathrm{p}=$ 0.0001 and 0.0027 , respectively; Fig. 3). However, the percent of the total CA activity in the intracellular fractions in D. gigas and L. brevis were very similar to each other, and distinct from the profile of $D$. pealeii (Fig. 4). In both D. gigas and D. pealeii the activity in the $\mathrm{s} 3$ fraction was significantly greater than either the $\mathrm{p} 3$ or $\mathrm{p} 1$ fraction (P $<0.0001$ for both comparisons; Fig. 3). Within the gills of $D$. pealeii the activity in the s3 fraction was 2-4 times the activity of that fraction from D. gigas and L. brevis, which was a significant amount $(\mathrm{P}<0.0001)$. The mitochondrial and cytoplasmic fractions were not different from each other in L. brevis, but both showed greater activity than the microsomal fraction. 


\section{Crude Homogenate}

D. gigas: $8683.65 \pm 403.1$ (5)

L. brevis: $8438.93 \pm 822.9$ (9)

D. pealeii: $8294.06 \pm 716.6(15)$

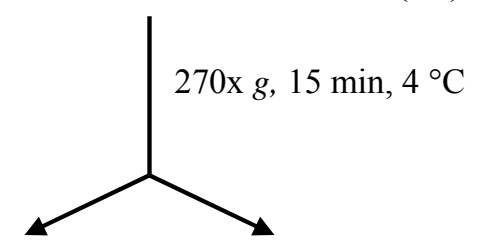

$\mathrm{P}_{1}$ (cell debris)

D. gigas: $1474.35 \pm 171.5$ (5)

L. brevis: $997.84 \pm 190.0$ (9) $b$

D. pealeii: $1216.11 \pm 95.5$ (13)

$\mathrm{S}_{1}$ (cytoplasm, microsomes, mitochondria)

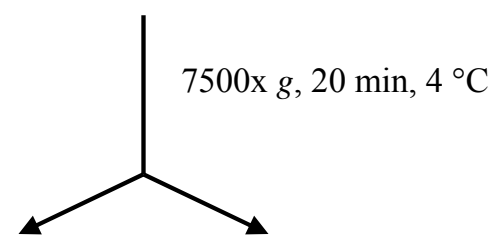

$\mathrm{P}_{2}$ (mitochondria)

D. gigas: $\mathbf{4 8 8 3 . 0 1} \pm \mathbf{3 8 3 . 5}$ (5) a

L. brevis: $2612.82 \pm 563.6$ (9) $a$

D. pealeii: $2231.79 \pm 178.6$ (13)

$\mathrm{S}_{2}$ (cytoplasm, microsomes)

$\mathrm{P}_{3}$ (microsomes)

D. gigas: $801.54 \pm 281.4$ (4)

L. brevis: $429.68 \pm 160.0$ (6) $b$

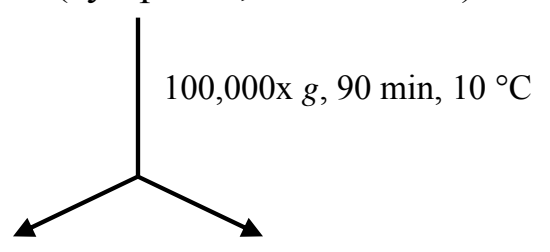

D. pealeii: $696.86 \pm 121.7$ (8)

$\mathrm{S}_{3}$ (cytoplasm)

D. gigas: $3711.58 \pm 186.3$ (5) $b$

L. brevis: $1907.08 \pm 311.2$ (7) $a$

D. pealeii: $7018.15 \pm 554.3$ (8) $a$

Figure 3. Schematic depicting the separation of gill tissues into subcellular components by differential centrifugation. The total CA activity (mean \pm SEM (n)) for each species, reported as $\mu \mathrm{mol} \mathrm{CO} 2 \cdot \mathrm{ml}^{-1} \cdot \mathrm{min}^{-1}$. Activities in bold indicate significantly different values between species with in a fraction. Letters denote differences between fractions within a species. Values to the right of the arrows columns are centrifugation force, duration, and temperature. Abbreviations are $\mathrm{P}=$ pellet, $\mathrm{S}=$ supernatant. Schematic modified from Henry et al., 1987.

In both $D$. gigas and L. brevis CA activity in the $\mathrm{p} 2$ fraction alone comprised $45 \%$ of the total activity (Fig. 4). Combined, the p2 and s3 fractional activity in the gills of each species was approximately $80 \%$ of the CA activity (Fig. 4). The CA activity in the s3 fraction of D. pealeii comprised $63 \%$ of the total gill activity (Fig. 4). In all species the activities in the $\mathrm{p} 1$ and $\mathrm{p} 3$ fractions were statistically the same, and occupied roughly the same percentage of total activity. This suggests that there is little 
CA bound to cell or organelle membranes. This was also observed in gills of $S$. officinalis (Schipp et al., 1979).

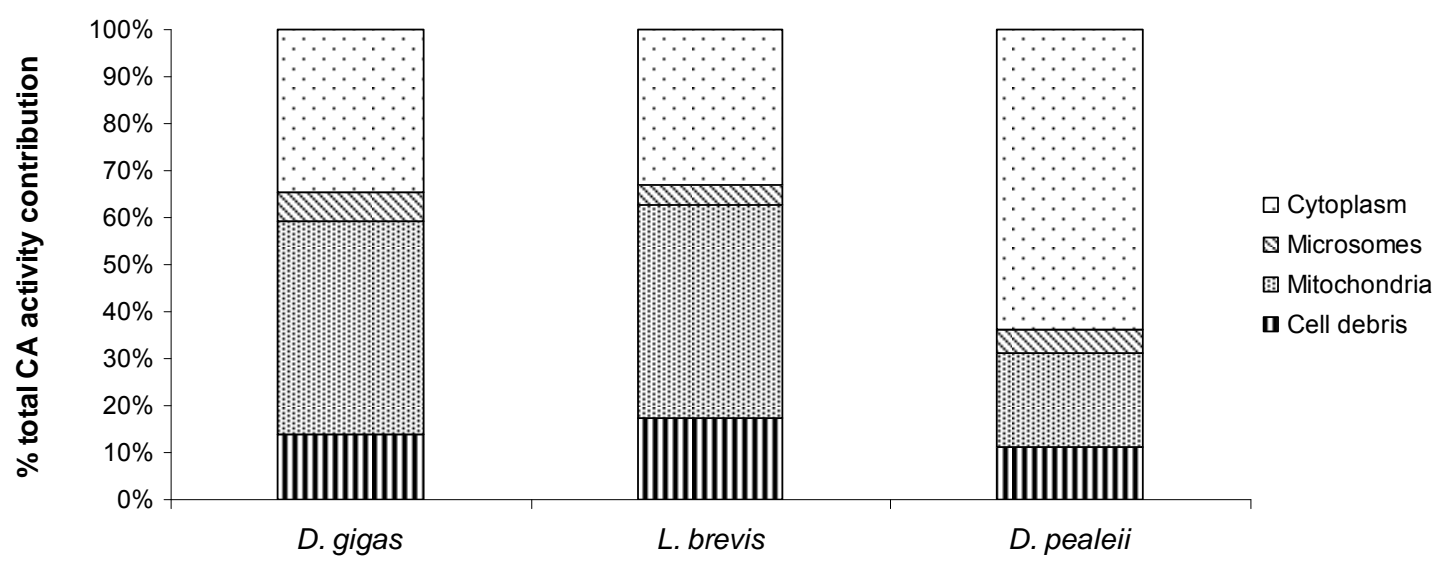

Figure 4. Intracellular fractional CA activity as a percent of the total activity in gill from three squid species. Values are percent of the cumulative activity of all fractions. Note the similarities in the relative contribution of mitochondrial and cytoplasm fractions in D. gigas and L. brevis.

The intracellular fraction in the muscle exhibited low CA activity in all three species. There were no significant differences in the CA activity of a given fraction between the species (Fig 5). The only significant differences among intracellular fractions in muscle were detected in the $\mathrm{s} 3$ fractions of L. brevis and D. pealeii ( $\mathrm{p} \leq$ 0.0302 for all comparisons). Any $\mathrm{CA}$ mediated interconversion of $\mathrm{CO}_{2}$ that occurs within the muscle cell is likely small, suggesting that a potentially large portion of the $\mathrm{CO}_{2}$ effluxes via passive diffusion. This may be a contributing factor to the larger than expected difference in arteriole and venous $\mathrm{pH}$ observed by Pörtner (1994), who postulated that cutaneous respiration in squids may be responsible for a substantial amount of their $\mathrm{O}_{2}$ uptake (and $\mathrm{CO}_{2}$ release). 


\section{Crude Homogenate}

D. gigas: $216.8 \pm 42.8$ (4)

L. brevis: $728.85 \pm 127.9$ (5)

D. pealeii: $317.76 \pm 128.3$ (5)

$\mathrm{P}_{1}$ (cell debris)

D. gigas: $41.28 \pm 11.0$ (3)

270x $g, 15 \min , 4^{\circ} \mathrm{C}$

L. brevis: $222.94 \pm 114.1$ (2)

D. pealeii: $106.49 \pm 31.1$ (6)

$\mathrm{S}_{1}$ (cytoplasm, microsomes, mitochondria)

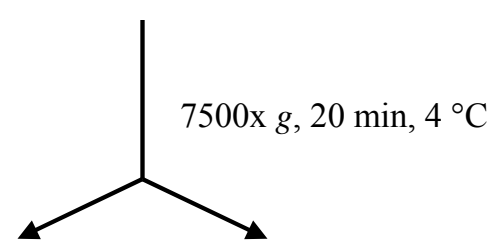

$\mathrm{P}_{2}$ (mitochondria)

$\mathrm{S}_{2}$ (cytoplasm, microsomes)

D. gigas: 43.17 (1)

L. brevis: $176.38 \pm 38.1$ (5)

D. pealeii: $149.0 \pm 45.7$ (5)

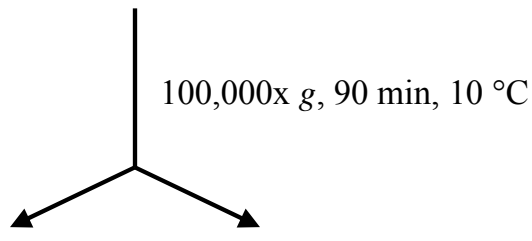

$\mathrm{P}_{3}$ (microsomes)

D. gigas: $158.81 \pm 73.9$ (3)

L. brevis: $141.21 \pm 82.3$ (3)

$\mathrm{S}_{3}$ (cytoplasm)

D. pealeii: $102.76 \pm 34.6$ (4)

D. gigas: $127.13 \pm 40.8$ (3)

L. brevis: $431.15 \pm 72.4$ (5)

D. pealeii: $393.67 \pm 177.4$ (5)

Figure 5. Schematic depicting the separation of mantle muscle tissues into subcellular components by differential centrifugation. The total CA activity (mean \pm $\mathrm{SEM}(\mathrm{n})$ ) for each species, reported as $\mu \mathrm{mol} \mathrm{CO}_{2} \cdot \mathrm{ml}^{-1} \cdot \mathrm{min}^{-1} \mathrm{x}$ dilution factor in $\mathrm{ml}$.

CA activity distribution along the length of gills in D. pealeii

Trends in each gill segment (anterior, middle, and posterior) of $D$. pealeii gills (Table 2) were generally reflective of the CA profile from whole gill (Fig. 4). Within each segment, the s3 fraction was significantly greater than any other intracellular compartments $(\mathrm{p}<0.0001$ in all comparisons; Table 2$)$. The $\mathrm{p} 2$ fraction was 
significantly greater than the $\mathrm{p} 3$ fraction in the mid-gill segment $(\mathrm{P}=0.0276)$, and both the $\mathrm{p} 3$ and $\mathrm{p} 1$ fractions in the posterior gill segment $(\mathrm{P}=0.0028$ and 0.005 , respectively). When each fraction was compared between the segments, the CA activity of the $\mathrm{p} 2$ fraction in the middle and posterior gill were significantly greater than the same fraction in the anterior gill segment $(\mathrm{P}<0.0001)$. This may be indicative of a shift in mitochondrial densities along the gill length.

The effect of washing $\mathrm{p} 1$ and $\mathrm{p} 2$ pellets on CA activities among gill segments in D. pealeii is shown in Table 3. The results show that in the p1 fraction of each segment, little activity was retained in the pellet after a second centrifugation. In other words, the majority of observed CA activity was liberated to the supernatant after washing. This indicates that there was possibly a substantial amount of CA trapped in the first centrifugation and values in Fig. 3 pl may be overestimates. Conversely, the majority of the activity in the $\mathrm{p} 2$ fraction was retained in the pellet after washing. This indicates that the CA activity observed in this fraction is largely due to mitochondrialbound CA (presumably CAV).

\section{Inhibition curves.}

The plots of the inhibitor titrations are presented in Fig 6 and the inhibition constants (Ki) and estimates of free enzyme concentrations (Eo) are shown in Table 4. All fractions measured showed high affinities for $\mathrm{Az}$ in all three species. In D. gigas, the $\mathrm{Ki}$ was similar among the fractions. The $\mathrm{Ki}$ for $\mathrm{Az}$ was about 4 times less in the mitochondrial fraction of $L$. brevis than in the other two species, and also in the 
Table 2. Distribution of CA activity in gill and mantle tissue from segments of $D$. pealeii gill. Values are means \pm SEM.

\section{Anterior gill}

\begin{tabular}{|c|c|c|c|c|c|}
\hline \multirow[b]{2}{*}{ Crude homogenate } & \multirow{2}{*}{$\frac{n}{4}$} & \multicolumn{3}{|c|}{$\mu \mathrm{mol} \mathrm{CO} \mathrm{CO}_{2} \cdot \mathrm{min}^{-1} \cdot \mathrm{g}^{-1}$} & \\
\hline & & 6064.92 & \pm & 1047.1 & \\
\hline Cell debris & 7 & 942.8 & \pm & 183.5 & $\mathrm{~b}$ \\
\hline Mitochondria & 6 & 1140.59 & \pm & 218.1 & $\mathrm{~b}$ \\
\hline Microsomes & 5 & 564.95 & \pm & 168.2 & $\mathrm{~b}$ \\
\hline Cytoplasm & 5 & 5623.13 & \pm & 804.8 & a \\
\hline
\end{tabular}

Mid-gill

\begin{tabular}{|c|c|c|c|c|}
\hline $\mathrm{n}$ & \multicolumn{3}{|c|}{$\mu \mathrm{mol} \mathrm{CO} \mathrm{CO}_{2} \cdot \mathrm{min}^{-1} \cdot \mathrm{g}^{-1}$} & \\
\hline 6 & 8909.91 & \pm & 423.9 & \\
\hline 7 & 1398.21 & \pm & 105.7 & $b, c$ \\
\hline 6 & 2624.38 & \pm & 185.8 & $b, \uparrow$ \\
\hline 5 & 578.56 & \pm & 135.0 & $\mathrm{C}$ \\
\hline 5 & 7037.16 & \pm & 1016.9 & a \\
\hline
\end{tabular}

Posterior gill

\begin{tabular}{|c|c|c|c|c|}
\hline $\mathrm{n}$ & \multicolumn{3}{|c|}{$\mu \mathrm{mol} \mathrm{CO} \mathrm{CO}_{2} \cdot \mathrm{min}^{-1} \cdot \mathrm{g}^{-1}$} & \\
\hline 5 & 9338.35 & \pm & 1756.0 & \\
\hline 10 & 1279.95 & \pm & 161.8 & $b$ \\
\hline 10 & 2650.96 & \pm & 165.1 & $b, \dagger$ \\
\hline 5 & 867.93 & \pm & 235.0 & $b$ \\
\hline 5 & 8394.15 & \pm & 764.7 & a \\
\hline
\end{tabular}

letters $a, b, c$ indicate significant differences from pair-wise comparisons of activity between intracellular fractions within a tissue of an individual segments

$\dagger$ denotes significant differences from pair-wise comparisons of activity between gill segments

Table 3. The effect of washing on CA activity from initial pellets of cell debris and mitochondrial fractions (from Table 2). Values are means \pm SEM.

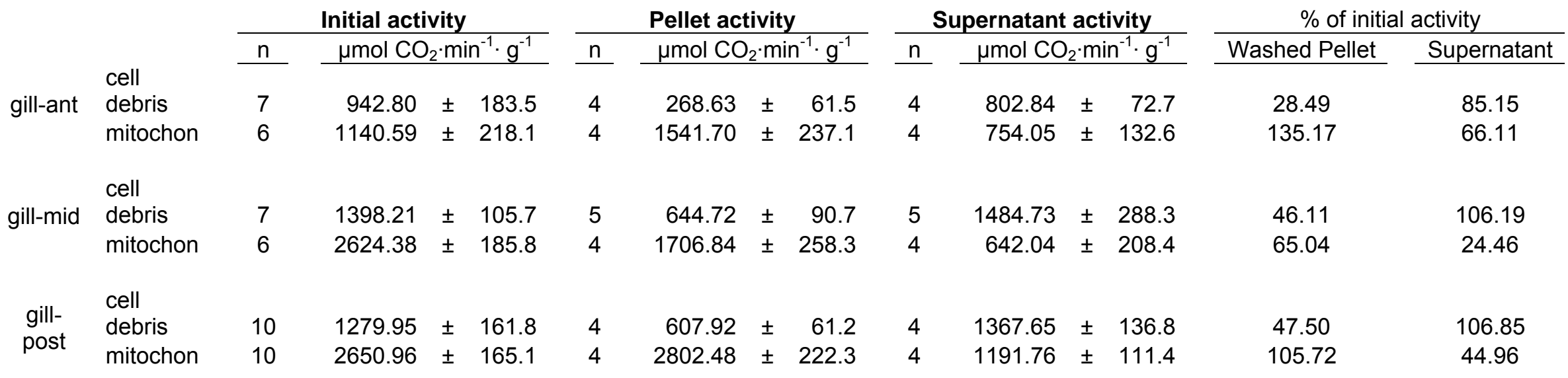


cytoplasmic fraction from L. brevis. Both the mitochondrial and cytoplasmic fractions in D. pealeii exhibited about 4 times greater affinity than the microsomal fraction. The affinity in the microsomal fraction of L. brevis could not be determined. The amount

A

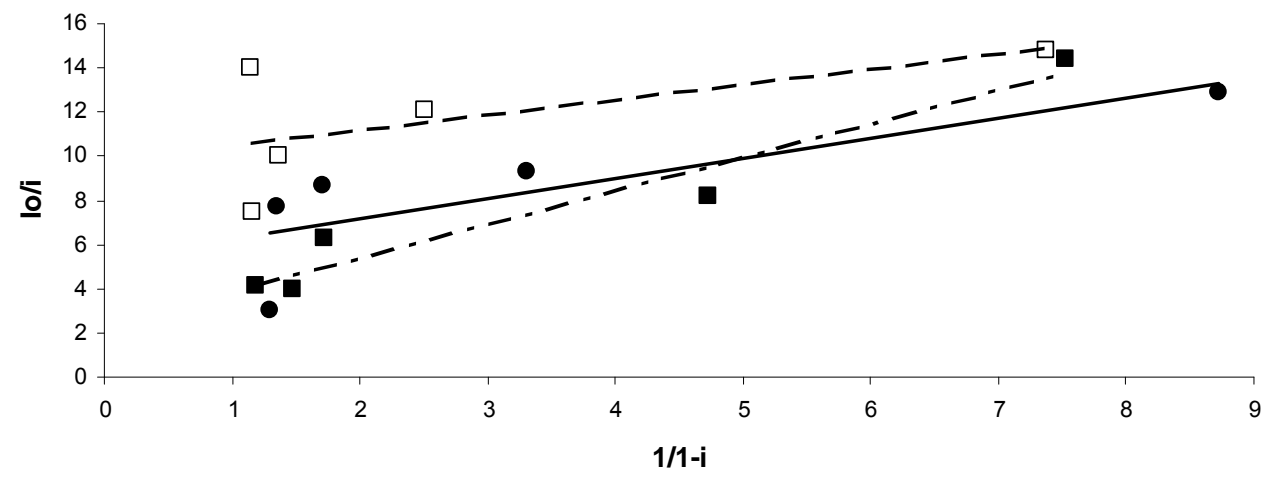

B

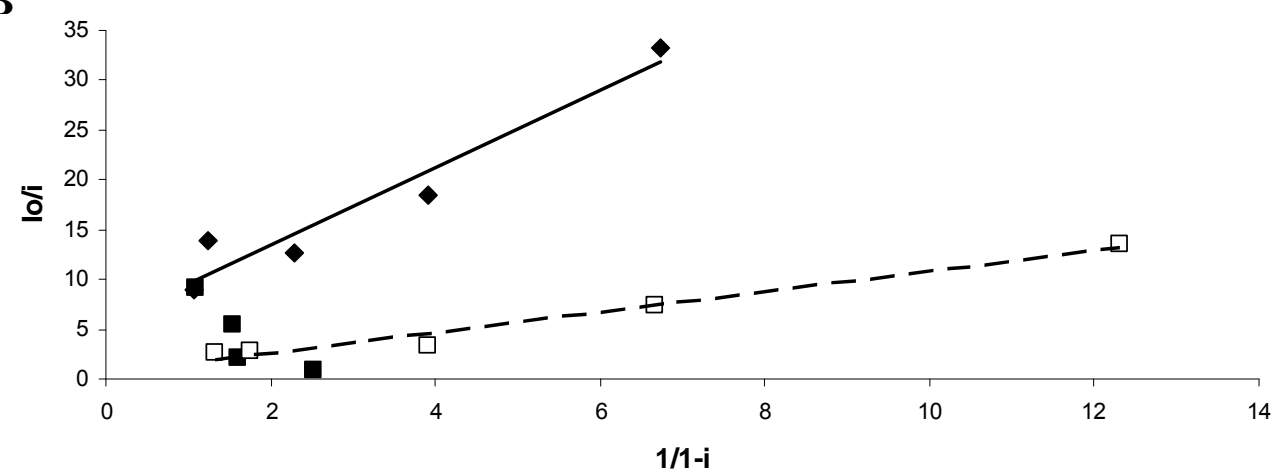

C

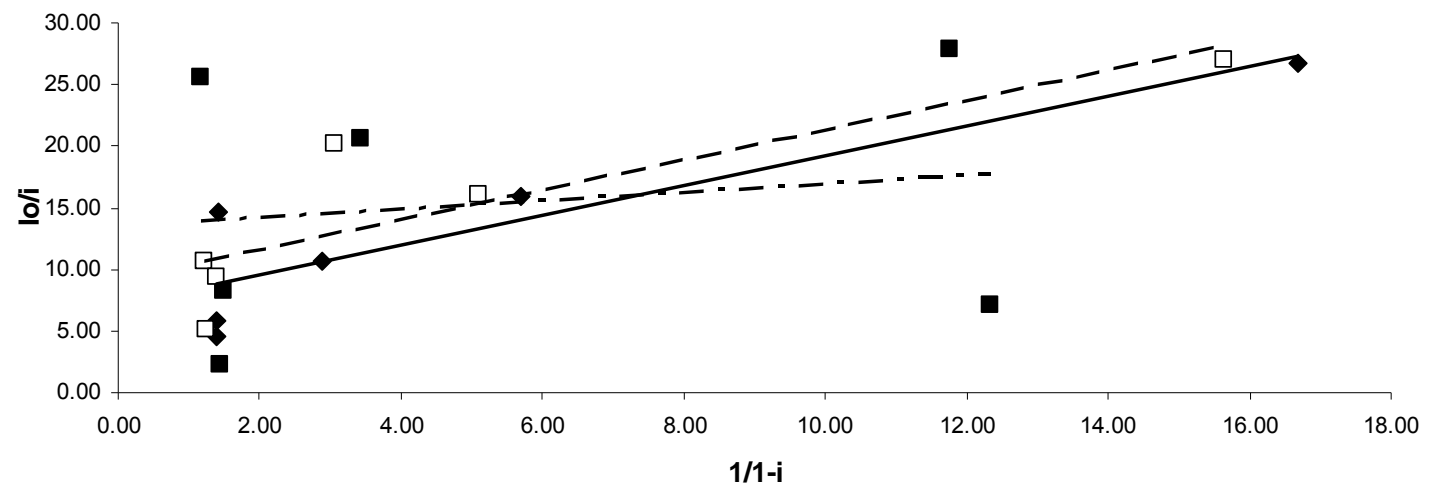

Figure 6. Double reciprocal inhibitor titration plots of CA activity from D. gigas (A), $L$. brevis (B), and $D$. pealeii $(\mathrm{C})$. The fractions in each plot are represented as: mitochondrial (p2, solid line), microsomal fraction (p3, -, semi-dashed line), and cytoplasm (s3, $\square$, dashed line). Data points for each fraction are a mean of 2-5 specimens for each fraction assayed in duplicate. 
of free enzyme (Eo) was similar among all three species in the mitochondrial fraction. The Eo was also similar between the cytoplasm in D. gigas and D. pealeii, and each species exhibited approximately 15 times greater free enzyme in this fraction than $L$. brevis.

Scaling of CA with mass and metabolism

The scaling of CA activity in crude gill and muscle homogenates as a function of animal mass (Fig. 7A and B) and of mass-specific metabolic rates (Fig. 7C and D)

Table 4. Inhibition constants (Ki) and enzyme concentrations (Eo) for CA from subcellular fractions

\begin{tabular}{|c|c|c|c|c|c|c|}
\hline \multirow[b]{2}{*}{ Fraction } & \multicolumn{2}{|c|}{ D. gigas } & \multicolumn{2}{|c|}{ L. brevis } & \multicolumn{2}{|c|}{ D. pealeii } \\
\hline & $\mathrm{Ki}(\mathrm{nM})$ & Eo (nM) & $\mathrm{Ki}(\mathrm{nM})$ & Eo (nM) & $\mathrm{Ki}(\mathrm{nM})$ & Eo (nM) \\
\hline mitochondria $(p 2)$ & 0.91 & 5.34 & 3.89 & 5.59 & 1.21 & 7.12 \\
\hline microsome $(p 3)$ & 1.15 & 2.39 & ----- & ------ & 0.35 & 13.46 \\
\hline cytoplasm (s3) & 0.69 & 9.82 & 1.03 & 0.62 & 1.22 & 9.13 \\
\hline
\end{tabular}

$$
Y=\mathrm{aX}^{\mathrm{b}}
$$

where $\mathrm{a}$ is a normalization constant, $\mathrm{b}$ is the scaling coefficient, and $\mathrm{X}$ is the independent variable. The metabolic rates for individual specimen were calculated using scaling parameters from Seibel, 2007 for each squid's respective family. The slope of the regression line for CA activity in gill as a function of either mass or massspecific MR was significantly different from zero in both comparisons. Thus the total CA activity in gill tissue appears to be independent of both squid mass and aerobic 
A

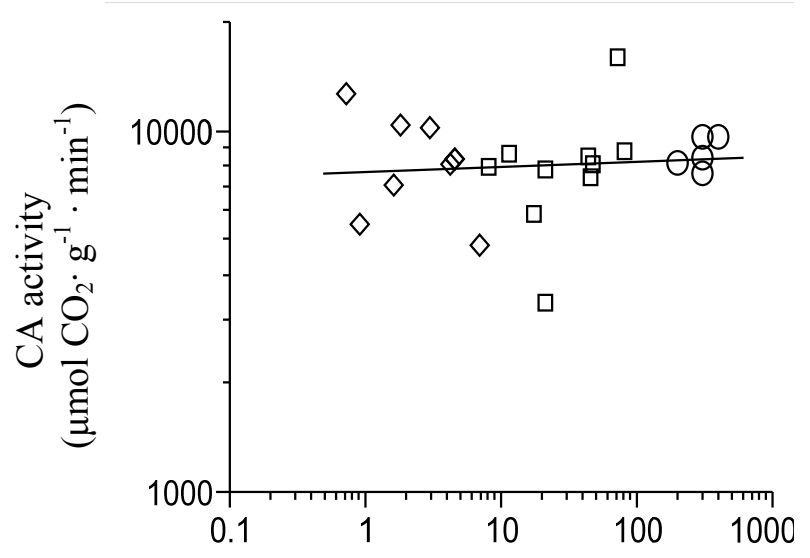

B

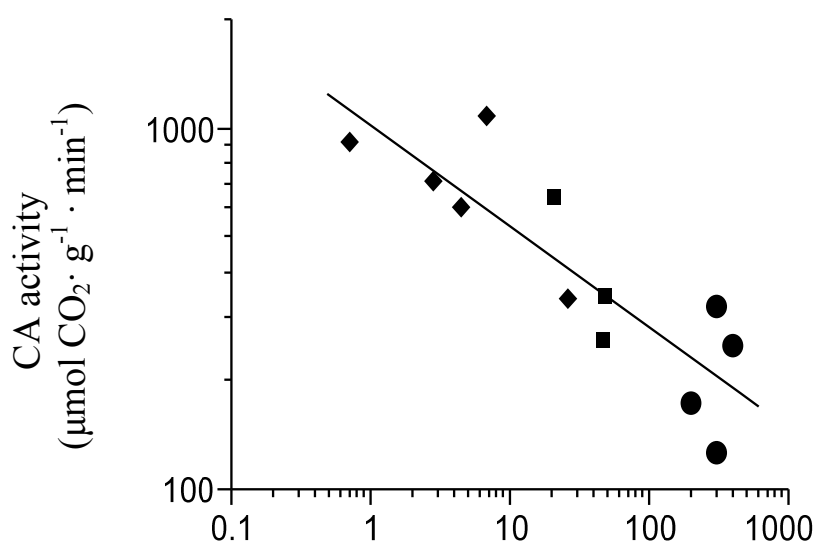

$\operatorname{Mass}(\mathrm{g})$
C

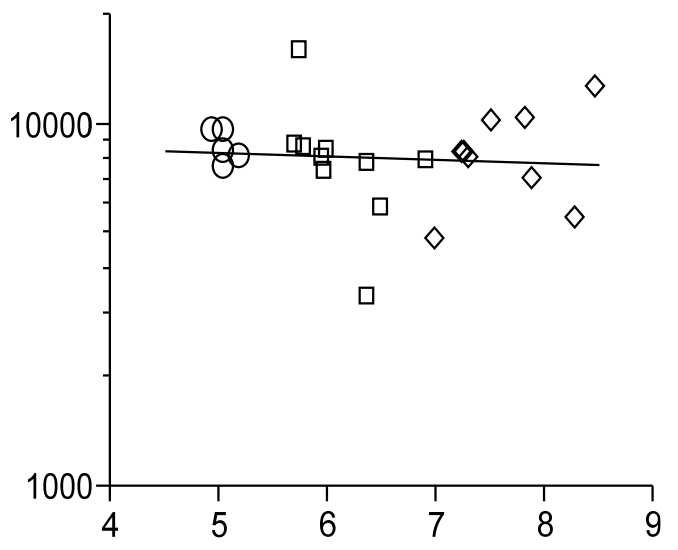

53

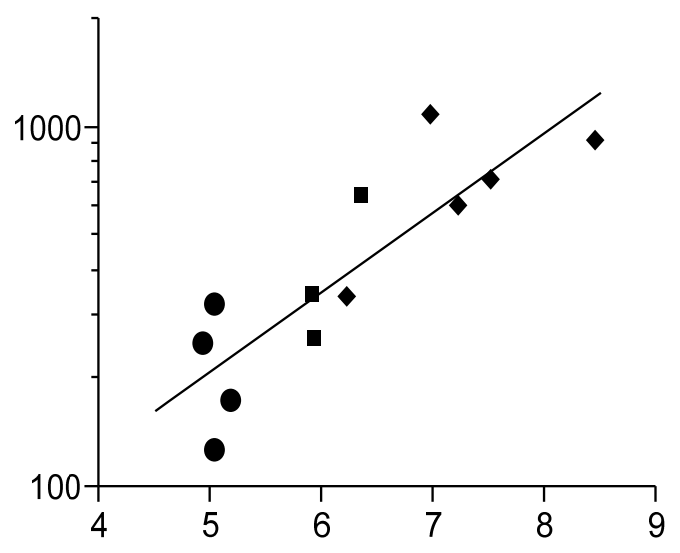

Mass-specific metabolic rate $\left(\mu \mathrm{mol} \mathrm{O}{ }_{2} \cdot \mathrm{g}^{-1} \cdot \mathrm{h}^{-1}\right)$

Figure 7. Carbonic anhydrase activity from crude homogenate as a function of squid mass (A and B) and estimate metabolic rate $(\mathrm{C}$ and $\mathrm{D})$. Open symbols represent $\mathrm{CA}$ activity in gill tissue and filled symbols for that in mantle muscle tissue. CA activity in the gills was independent of body mass (A) and whole animal metabolic rate $(\mathrm{C})(\mathrm{P}=$ 0.677 and 0.648 , respectively). B) There was a significant correlation between squid mass and muscle CA activity $\left(\mathrm{P}=0.0003, r^{2}=0.74\right)$ with a slope $(-0.28)$ close to that of the widely-observed scaling exponent of -0.25 , but steeper than that observed for these squid species (Seibel, 2007). D) Reflective of (B), the relationship between mass-specific MR and CA activity was also significant $\left(\mathrm{P}=0.0003, r^{2}=0.75\right)$ with smaller squids with higher metabolic rates exhibiting greater CA activity. Symbols for species are: L. brevis $(\diamond, \diamond), D$. pealeii $(\square, \varpi)$, and D. gigas $(\circ, \bullet)$.

mass-specific metabolic rate. Mantle muscle CA activity versus mass, however, exhibited a significant $(\mathrm{P}=0.0003)$ and fairly strong correlation $\left(r^{2}=0.74\right.$, Fig. $\left.7 \mathrm{~B}\right)$. 
The slope of this comparison was -0.28 (Table 5), which is very close to the massspecific aerobic metabolic rate scaling exponent of -0.25 broadly observed among organisms (Kleiber, 1932). There was also a significant positive slope when CA activity in muscle tissue was compared to mass-specific metabolic rate that showed a fairly strong correlation $\left(r^{2}=0.75\right.$; Fig. 7D).

The relationship between CA activity and body mass and mass-specific MR among the subcellular fractions was also examined. Table 5 presents the normalization constants, scaling coefficients, and P-values of the slopes among the fractions for both gill and muscle tissue. Except for the cytoplamic fraction, no other subcellular fractions showed a significant relationship to body mass or MR in either tissue (Table 5). The CA activity in the cytoplasmic fraction (s3) as a function of both mass and MR between the species was significant in gill and muscle tissue (Table 5, Fig. 8). There is an apparent change in the proportion of cytoplasmic CA activity between the tissues in relation to increasing animal mass and MR. Although the cytoplasmic activity in gills

was significantly greater in D. pealeii (Fig 3), the larger species (D. gigas), with a comparatively lower metabolic rate, has a greater proportion of gill:muscle CA activity (103.1 compared to 17.8).

\section{Discussion}

This study was the first to systematically measure and compare CA activity in squids. We examined the total and intracellular activity of CA in gill and mantle 
Table 5. Carbonic anhydrase subcellular activity $\left(\mu \mathrm{mol} \mathrm{CO} \mathrm{CO}^{-1} \cdot \mathrm{min}^{-1}\right)$ as a function of squid mass $(\mathrm{M})$ and metabolic rate $\left(\mathrm{Mo}_{2}\right)$ in gill and muscle tissue

\begin{tabular}{|c|c|c|c|c|c|c|c|c|c|c|}
\hline \multirow[b]{2}{*}{ Tissue/fraction } & \multicolumn{5}{|c|}{$C A=a M^{b}$} & \multicolumn{5}{|c|}{$\mathrm{CA}=\mathrm{aMo}_{2}^{\mathrm{b}}(\mathrm{umol} \mathrm{O} 2 / \mathrm{g} / \mathrm{h})$} \\
\hline & $\mathrm{n}$ & a & $\mathrm{b}$ & r2 & $\begin{array}{c}\text { P-value } \\
\text { (slope) }\end{array}$ & $\mathrm{N}$ & a & $\mathrm{b}$ & r2 & $\begin{array}{c}\text { P-value } \\
\text { (slope) }\end{array}$ \\
\hline \multicolumn{11}{|l|}{ Gill } \\
\hline Crude homogenate & 24 & 8.96 & 0.015 & 0.01 & 0.68 & 24 & 9.33 & -0.18 & 0.01 & 0.65 \\
\hline Cell debris ( $p 1)$ & 32 & 6.776 & 0.067 & 0.06 & 0.17 & 32 & 8.416 & -0.78 & 0.07 & 0.15 \\
\hline Mitochondria (p2) & 30 & 7.546 & 0.072 & 0.04 & 0.28 & 30 & 9.481 & -0.93 & 0.05 & 0.22 \\
\hline Microsome (p3) & 20 & 5.752 & 0.132 & 0.07 & 0.27 & 20 & 8.82 & -1.45 & 0.06 & 0.28 \\
\hline Cytoplasm (s3) & 27 & 7.529 & 0.234 & 0.33 & 0.0017 & 27 & 12.693 & -2.41 & 0.28 & 0.0045 \\
\hline \multicolumn{11}{|l|}{ Muscle } \\
\hline Crude homogenate & 12 & 6.927 & -0.28 & 0.74 & 0.0003 & 12 & 0.03 & 3.28 & 0.75 & 0.0003 \\
\hline Cell debris ( $p 1)$ & 11 & 5.44 & -0.27 & 0.29 & 0.09 & 11 & -1.08 & 3.09 & 0.31 & 0.0758 \\
\hline Mitochondria (p2) & 11 & 5.139 & -0.108 & 0.06 & 0.4524 & 11 & 2.253 & 1.38 & 0.08 & 0.3981 \\
\hline Microsome (p3) & 10 & 4.386 & 0.075 & 0.04 & 0.5821 & 10 & 6.142 & -0.83 & 0.04 & 0.574 \\
\hline Cytoplasm (s3) & 11 & 6.389 & -0.258 & 0.4 & 0.0361 & 11 & 0.269 & 2.9 & 0.41 & 0.0326 \\
\hline
\end{tabular}


tissues and along the length of the gills in D. pealeii, and how CA activity scales with body mass and metabolic rate. The three squids selected for this study all have similarly high routine metabolic rates, and D. pealeii and L. brevis are both coastal squids within the same family. However, D. gigas and L. brevis are each adapted to potentially physiologically stressful environments while $D$. pealeii is not. Considering these features, we also attempted to discern to what extent CA activity is indicative of aerobic metabolic rate, environmental adaptation, or evolutionary relationship. The main findings were that 1 ) total CA activity in gills was far greater, (15-45x), than in mantle muscle; 2) CA activity was largely in the cytoplasm and mitochondria in the gills of these three species, while muscle CA was uniformly very low in all fractions; 3) the CA activity within each intracellular pool as a percent of the total activity (i.e. CA profile) was similar between D. gigas and L. brevis; 4) total CA activity in gill was independent of animal mass and mass-specific MR, but exhibited a fairly strong correlation in mantle muscle; and 5) activity in the s3 fractions in both gill and muscle was significantly correlated to both mass and metabolic rates among the three species.

Total and fractional CA activity in mantle muscle was significantly lower than the activity in gill tissue in these squids. Because these are negatively buoyant animals that must continuously swim to maintain position in the water columns, muscle tissue likely generates the bulk of the $\mathrm{CO}_{2}$ produced. It is possible that with such little $\mathrm{CA}$ activity in the mantle muscle, the bulk of $\mathrm{CO}_{2}$ produced diffuses into the blood vessels where it acidifies the hemolymph. Some $\mathrm{CO}_{2}$ may also diffuse out of the animal and into the surrounding water, which has previously been proposed (Pörtner, 1994). The 
A

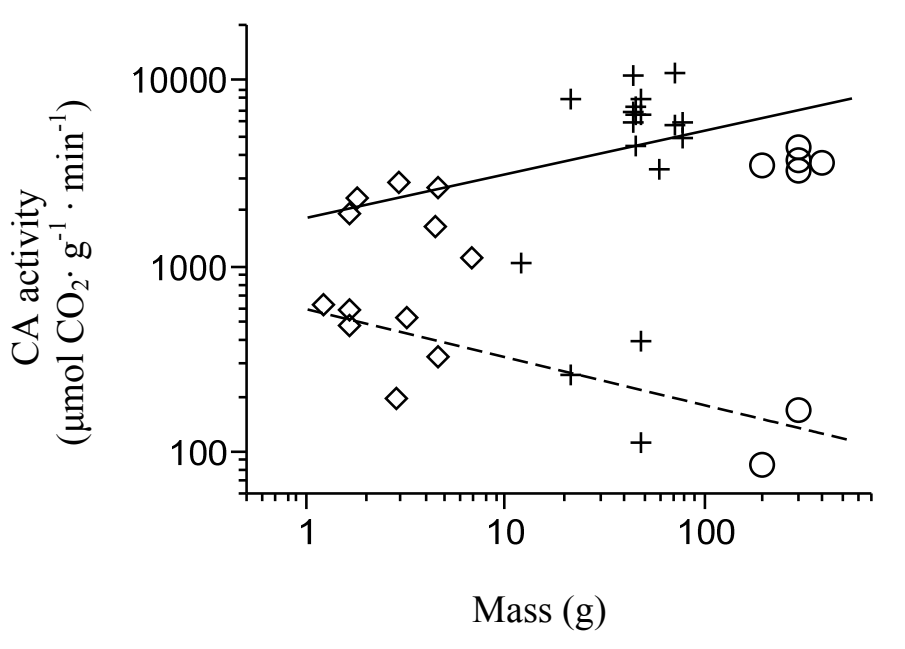

B

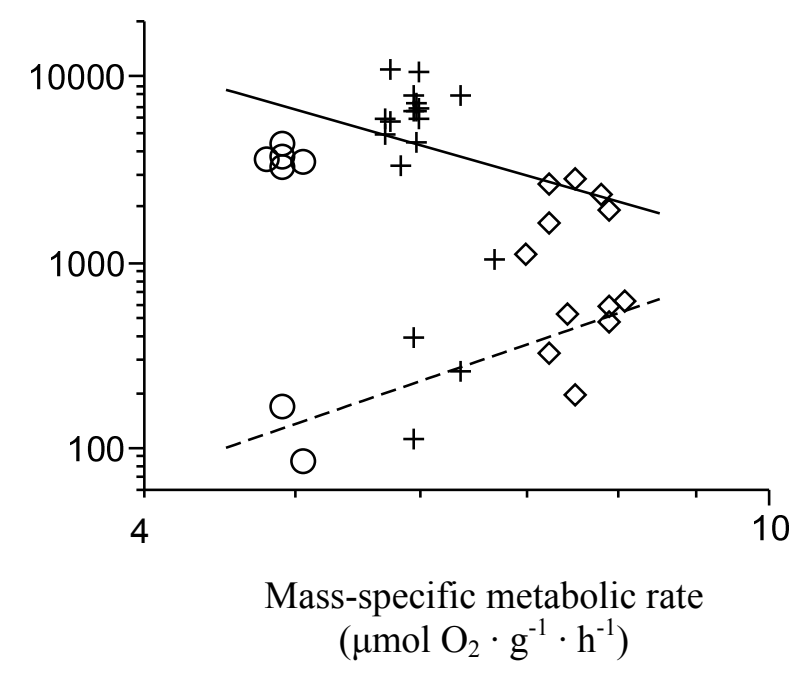

Figure 8. CA activity in the cytoplasmic fraction in gill (solid line) and mantle muscle (dashed line) in relation to squid mass (A) and mass-specific MR (B). A) Diverging CA activity between the tissues in relation to squid mass. Both the increase in gill cytoplasm CA activity with increasing mass and decrease in mantle muscle activity were significant $(P=0.0017$ and 0.0364 , respectively). Gill CA from other fractions showed no significant relationship (Fig. 3), and crude homogenate seems independent of body mass in these species. Cytoplasmic CA as a function of body mass exhibited a similar slope (-0.26) to that of crude homogenate and squid mass. B) Mirroring the trend with mass, the relationships between cytoplasmic CA activity in the cytoplasm of gills and mantle muscle were each also significant $(\mathrm{P}=$ 0.0045 and 0.0326 , respectively). Symbols for species are the same as in figure 7 . 
mean muscle CA activity in L. brevis was nearly $10 \%$ of the total gill activity, and $\sim 3 \mathrm{x}$ greater than muscle CA activity in D. pealeii and D. gigas. However, the mantle is considerably thinner than the two other species (pers. obs.), indicating a greater surface area to volume ratio that would facilitate $\mathrm{CO}_{2}$ diffusion. Proportionally more CA in L. brevis mantle muscle may aid this species' adaptation to its euryhaline environment by acting as a secondary osmoregulatory organ. This is not unlike the proposed role of squid mantle as a respiratory organ, which is hypothesized to supply as much as $90 \%$ of the oxygen demand via cutaneous respiration (Pörtner, 1994). Although there some evidence that surface area to volume ratios increase during squid ontogeny (O'Dor and Hoar, 2000), the larger D. gigas and D. pealeii likely have lower surface area:volume. This may lessen the diffusion of $\mathrm{CO}_{2}$ across the mantle and increase the amount diffusing into the blood. The proportionally greater gill:muscle ratio for $\mathrm{CA}$ activity with increasing mass may be due to an increased demand on the gills to maintain the $\mathrm{CO}_{2}$ gradient out of the system. The considerable amount of cytoplasmic CA activity exhibited in all three species lends some support to this.

In addition to being the primary respiratory organs, gills also serve as an important $\mathrm{pH}$ and osmoregulatory organs in many aquatic organisms (Wright et al. 1989; Boucher-Rodoni and Mangold, 1994; Henry, 1996). The cytoplasmic CA could supply counter-ions to aid osmoregulation $\left(\mathrm{H}^{+}\right.$and $\mathrm{HCO}_{3}{ }^{-}$for $\mathrm{Na}^{+}$and $\left.\mathrm{Cl}^{-}\right)$similar to that observed in fishes (Conley and Mallatt, 1987; Henry et al., 1988; Wright et al., 1989) (Fig 9). The excretion of $\mathrm{HCO}_{3}{ }^{-}$from the gill via ion exchangers would prevent intracellular accumulation, curtail the CA reaction from running towards dehydration, and further facilitate the gradient of gaseous $\mathrm{CO}_{2}$ out of the blood. CA activities from 
the microsomal fractions of $D$. pealeii gill segments were low, suggesting that there is little membrane-bound CA. A similar distribution was found by Shipp et al., (1979) in S. officinalis gill. Using microscopic techniques, they found minimal CA in the basal lamella or microvilli in the outer (respiratory) section. The techniques used in our study did not allow us to determine if the microsomal CA was apical or baso-lateral. However, some of the membrane bound $\mathrm{CA}$ in these squids likely has access to dehydrate $\mathrm{HCO}_{3}{ }^{-}$in the blood. Substantial microsomal CA activity, such as that seen in the C. granulata (Lopez-Mananes, 2000), may not been needed in squids because low venous $\mathrm{pH}$ may be sufficient to drive the reaction towards $\mathrm{CO}_{2}$ formation (Portner, 1994).

Squids are ammoniatelic organisms, with protein as the primary fuel source, and the gills are a main organ for ammonia excretion (Lee, 1994; Boucher-Rodoni and Mangold, 1994). CA has been shown to aid ammonia excretion in fish (Wright et al., 1989; Wilke 1997). However, their proposed mechanism involves CAs attached to the apical membranes that hydrate $\mathrm{CO}_{2}$ in the boundary layer to provide the $\mathrm{H}^{+}$for $\mathrm{NH}_{3} / \mathrm{NH}_{4}{ }^{+}$conversion. The nominal membrane-bound CA found in squid gills might function similarly, depending on its location. Unfortunately, the method we employed could not determine precisely where membrane-bound CA, if present, was located. Cytochemical analysis in S. officinalis places most of the CA primarily in the concave, mitochondrial-rich inner gill lamellae (Schipp et al., 1979; Boucher-Rodoni and Mangold, 1994). The mitochondrial CA in D. gigas may contribute protons for intracellular $\mathrm{NH}_{3} / \mathrm{NH}_{4}{ }^{+}$conversion prior to excretion (Boucher-Rodoni and Mangold, 1994) (Fig 9). This could be especially necessary as D. gigas repays its oxygen debt 
upon returning to the surface and excretes ammonia accrued while at depth. The mitochondrial CA activity measured in L. brevis may function similarly. However, $L$.

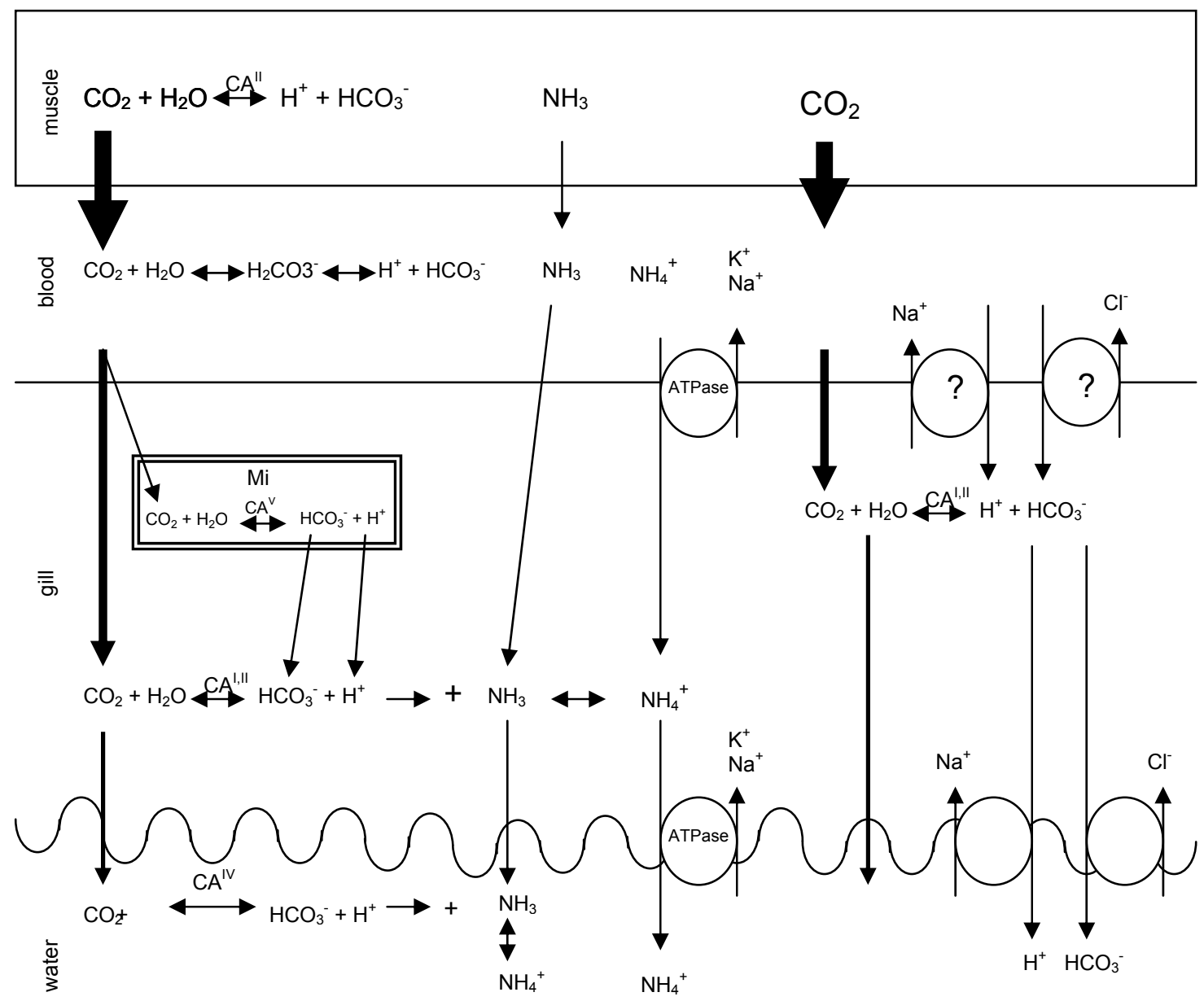

Figure 9. Schematic representation of distribution of intracellular CA isozymes and multiple physiological roles in $\mathrm{CO}_{2}$ and ammonia excretion and ion-exchange. $\left(\mathrm{NH}_{4} / \mathrm{K}^{+}\right.$ $+\mathrm{Na}^{+}$ATPase mechanism was redrawn from Boucher-Rodoni and Mangold, 1994). Arrow weight for $\mathrm{CO}_{2}$ indicates amount of molecular or gaseous $\mathrm{CO}_{2}$

brevis does not undergo diel vertical migrations. So excursions into low oxygen are likely not as prolonged or hypoxic as those experienced by D. gigas. Activity in this species may be more related to aiding ion-balance due to excursions into hyposaline waters rather than ammonia excretion. 


\section{CA profile and environmental adaptation.}

The percent contribution of CA activity among the intracellular fractions (CA profile) was more similar between D. gigas and L. brevis (Fig. 4). This could be interpreted as a result of adaptation to their respective environmental demands on physiological processes since $D$. pealeii and $L$. brevis are more closely related phylogenetically than either are to D. gigas. If the distribution of CA isozymes was representative of evolutionary relationships, then the CA profile between the Loliginids would be expected to more closely resemble each other. Genetic studies on CA in squids or investigations into CA isozyme activity using other members in these families should be done to make this connection clearer.

Conclusions:

This was the first study to characterize CA in squids. The total CA activity in gill tissue was over an order of magnitude greater than in mantle muscle for each of the three species: Dosidicus gigas, Lolliguncula brevis, and Doryteuthis pealeii. There was no difference in the total activity of either tissue among the species. This could be due to the similar aerobic metabolic rates between these species, however CA activity scaled independent of both body mass and mass-specific metabolic rate. Examination of CA activity in intracellular fractions from the gills revealed that the vast majority of CA activity lies in the cytoplasm and mitochondria, with very little in the membranous fractions (cell-debris and microsomes). The CA profiles were more similar between $D$. gigas and $L$. brevis, suggesting that environmental adaptations may influence the intracellular distribution of $\mathrm{CA}$ in squids more than phylogenetic relationships. 
Overall, these results highlight the importance of considering the contribution isozymes to respiratory and metabolic processes that involve carbonic anhydrase.

\section{Acknowledgements}

Thank you to A. Maia and S. Bush for helpful comments and feedback on the manuscript, and to L. Trueblood, J. Szczepanski, R. Rosa, L. Elder, A. Maas, J. Schneider and R. Wigton for their help with tissue collection. Special thanks to the crew of the R/V New Horizon and S. Fate at VIMS Eastern Shore Labs.

\section{Funding}

Funding for this research was provided by a National Science Foundation to BAS [OCE-0526493] and a Journal of Experimental Biology Travel Fellowship to ACN. 


\section{Literature cited}

Addink, A.D.F. (1971). Carbonic anhydrase in Sepia officinalis L. Comp. Biochem. and Physiol. Part B: Comp. Biochem. 38: 707-721.

Baillie, B.K. and D. Yellowlees. (1998). Characterization and function of carbonic anhydrases in the zooxanthellae-giant clam symbiosis. Proc. R. Soc. Lond. B. 265: $465-473$.

Bartol, I.K., Mann, R., and M. Vecchione. (2002). Distribution of the euryhaline squid Lolliguncula brevis in Chesapeake bay: effects of selected abiotic factors. Mar. Ecol. Prog. Ser. 226: 235 - 247.

Boucher-Rodoni, R. and K. Mangold. (1994). Ammonia production in Cephalopods, physiological and evolutionary aspects. In: Physiology of Cephalopod Molluscs: Lifestyle and Performance Adaptations. Eds. Pörtner, H.O., O’Dor, R.K., and Macmillan, D.L.Gordon and Breach Science Publishers S.A., U.S. pp 53-60.

Brodziak, J. and L. Hendrickson (1999). An analysis of environmental effects on survey catches of squids Loligo pealeii and Illex illecebrosus in the northwestern Atlantic. Fish. Bull. 97: 9-24.

Castilho, P.D., Martins, I.A., and A. Bianchini. (2001). Gill Na ${ }^{+}, \mathrm{K}^{+}$-ATPase and osmoregulation in the estuarine crab, Chasmagnathus granulata Dana, 1851 (Decapoda, Grapsidae). J. Exp. Mar. Biol. and Ecol. 256: 215-227.

Castillo, J.P., De Giorgis, D., Basilio, D., Gadsby, D.C., Rosenthal, J.J.C., Latorre, R., Holmgren, M., and F. Bezanilla. (2011). Energy landscape of the reactions governing the $\mathrm{Na}^{+}$deeply occluded state of the $\mathrm{Na}^{+} / \mathrm{K}^{+}$-ATPase in the giant axon of the Humboldt squid. PNAS 108: 20559-20561.

Coleman, J.R. and A.R. Grossman. (1984). Biosynthesis of carbonic anhydrase in Chlamydomonas reinhardtii during adaptation to low $\mathrm{CO}_{2}$. Proc. Natl. Acad. Sci. 81: 6049-6053.

Conley, D.M. and J. Mallat. (1988). Histochemical localization of $\mathrm{Na}^{+}-\mathrm{K}^{+}$ATPase and carbonic anhydrase in gills of 17 fish species. Can. J. Zool. 66: 2398-2405.

David, E., Tanguy, A., Pichavant, K., and D. Moraga. (2005). Response of the Pacific oyster Crassostrea gigasto hypoxia exposure under experimental conditions. FEBS. 272: 5635-5652. 
Dawe, E.G., Hendrickson, L.C., Colbourne, E.B., Drinkwater, K.F., and M.A. Showell. (2007). Ocean climate effects on the relative abundance of shortfinned (Illex illecebrosus) and long-finned (Loligo pealeii) squid in the northwest Atlantic Ocean. Fish. Oceanog. 16: 303 - 316.

DeJours, P. (1981). Principles of Comparative Respiratory Physiology. $2^{\text {nd }}$ Ed. New York: Elsevier/North-Holland Press. 265 pp.

Donaubauer, H.H. and R. Schipp. (1978). The localization of enzyme activities in the pancreatic appendages of Sepia officianlis L. (Cephalopoda). Histochem. 59: $29-44$.

D'Orazio, S.E. and C.W. Holliday (1985). Gill Na,K-ATPase and osmoregulation in the sand fiddler crab, Uca pugilator. Physiol. Zool. 58: 364-373.

Easson, L.H. and E. Stedman. (1937). The absolute activity of choline esterase. Proc. Roy. Acad. Sci. 121B: 142-164.

Edsall, J.T. (1968). Carbon diox-ide, carbonic acid, and biocarbonate ion: Physical properties and kinetics of interconversion. In " $\mathrm{CO}_{2}$ : Chemical, Biochemical and Physiological Aspects" R.E. Foster, J.T. Edsall, A.B. Otis, and F.J.W. Roughton eds). pp. 15-28. NASA SP \#118, Washington, D.C.

Fabry, V.J., Seibel, B.A., Feely, R.A., and J.C. Orr (2008). Impacts of ocean acidification on marine fauna and ecosystem processes. ICES J. Mar. Sci. 65: 414-432.

Fiedler, P.C. and L.D. Talley. (2006). Hydrography of the eastern tropical Pacific: a review. Prog. Oceano. 69: $143-180$.

Forster, .R.E., Obaid, A.L., Crandall, E.D., and N. Itada. (1980). $\mathrm{Cl}^{-}$and $\mathrm{HCO}_{3}{ }^{-}$ movements across the red blood cell membrane. In: Biophysics and physiology of carbon dioxide. C. Bauer, G. Gros, and H. Bartels eds. Springer-Verlag, NY pp.285-290.

Geers and Gros (2000). $\mathrm{CO}_{2}$ transport and CA in blood and muscle. Phys. Rev. 80(2) 681-715.

Gilly, W.F., Markaida, U., Baxter, C.H., Block, B.A., Boustany, A., Zeidberg, L., Reisenbichler, K., Robison, B., Bazzino, G., and C. Salinas. (2006). Vertical and horizontal migrations by the jumbo squid Dosidicus gigas revealed by electronic tagging. Mar. Ecol. Prog. Ser. 324: 1 - 17.

Hanlon, R.T. and J.B. Messenger (2005). Cephalopod behavior. Cambridge University Press, 40 W 20th Street, New York, NY. 
Hendrix, J.P., Hulet, W.H., and M.J. Greenberg. (1981). Salinity tolerance and the response to hypoosmotic stress of the bay squid Lolliguncula brevis, a euryhaline cephalopod mollusc. Comp. Biochem. Physiol. A 69: 641-648.

Henry, R.P. (1984). The role of carbonic anhydrase in blood ion and acid-base regulation. Amer. Zool. 24: 241-251.

Henry, R.P. (1987). Membrane-associated carbonic anhydrase in the gills of the blue crab, Callinectes sapidus. Amer. J. Physiol. 252: 959-965.

Henry, R.P. (1988a). Multiple functions of carbonic anhydrase in the crustacean gill. J. Exper. Zool. 248: 19-24.

Henry, R.P. (1988). Subcellular distribution of carbonic anhydrase activity in gills of the blue crab, Callinectes sapidus. J. Exp. Zool. 245: 1-8.

Henry, R.P. (1996). Multiple roles of carbonic anhydrase in cellular trasnport and metabolism. Annu. Rev. Physiol. 58: 523-538.

Henry, R.P. (2001). Environmentally mediated carbonic anhydrase induction in the gills of euryhaline crustaceans. J. Exp. Biol. 204: 991 - 1002.

Henry, R.P. (1991a). Techniques for measuring carbonic anhydrase activity in vitro: The electrometric delta $\mathrm{pH}$ method and the $\mathrm{pH}$ stat method. In: The Carbonic Anhydrases: Cellular, Phyiology, and Molecular Genetics (eds. S.J. Dodgson, R.E. Tashian, G. Gros and N.D. Carter), New York: Plenum. pp. 119 -125 .

Henry, R.P. (1991b). Branchial and branchiostegite carbonic anhydrase in decapod crustaceans: the aquatic to terrestrial transition. J. Exp. Zool. 259: 294-303.

Henry, R.P. and J.N. Cameron. (1982a). Acid-base balance in Callinectes sapidus during acclimation from high to low salinity. J. Exp. Biol. 221: 309-321.

Henry, R.P. and J.N. Cameron. (1982b). The distribution and partial characterization of carbonic anhydrase in selected aquatic and terrestrial decapod crustaceans. J. Exp Zool. 221: 309-321.

Henry, R.P. and J.N. Cameron. (1983). The role of carbonic anhydrase in respiration, ion regulation and acid-base balance in the aquatic crab Callinectes sapidus and the terrestrial crab Gecarcinus lateralis. J. Exp. Biol. 103: 205223.

Henry, R.P. and D.G. Saintsing. (1983). Carbonic anhydrase activity and ion regulation in three species of osmoregulating bivalve molluscs. J. Phyiol. Zool. 56: $274-280$. 
Henry, R.P. and M. G. Wheatly. (1992). Interactions of respiration, ion regulation, and acid-base balance in everyday life of aquatic crustaceans. Amer. Zool. 32: 407-416.

Henry, R.P., Smatresk, N.J., and J.N. Cameron. (1988). The distribution of branchial carbonic anhydrase and the effects of gill and erythrocyte carbonic anhydrase inhibition in the channel catfish Ictalurus punctatus. J. Exp. Biol. 134: $201-218$.

Henry, R.P., Gehnrich, S., Weihrauch, D., and D.W. Towle. (2003). Salinitymediated carbonic anhydrase induction in the gills of the euryhaline green crab, Carcinus maenas. Comp. Biochem. Physiol. A. 136: 243-258.

Khalifah, R.G. and Silverman, D.N. (1991). Carbonic anhydrase kinetics and molecular function. In: The Carbonic Anhydrases: Cellular, Phyiology, and Molecular Genetics (eds. S.J. Dodgson, R.E. Tashian, G. Gros and N.D. Carter), New York: Plenum. pp. $49-70$.

Kleiber, M. (1932). Body size and metabolism. Higlardia 6: 315-352.

Klocke, R.A. (1980). Carbonic anhydrase in lung tissue In: Biophysics and physiology of carbon dioxide. C. Bauer, G. Gros, and H. Bartels eds. SpringerVerlag, NY pp. 331-338.

Kochevar, R.E. and J.J. Childress. (1996). Carbonic anhydrase in deep-sea chemoautotrophic symbioses. Mar. Biol. 125: 375 - 383.

Lee, P.G. (1994). Nutrition in cephalopods: fueling the system. In: Physiology of Cephalopod Molluscs: Lifestyle and Performance Adaptations. Eds. Pörtner, H.O., O’Dor, R.K., and Macmillan, D.L.Gordon and Breach Science Publishers S.A., U.S. pp $35-51$.

Lopez Mananes, A.A., Magnoli, L.J. and A.L. Goldemberg. (2000). Branchial carbonic anhydrase (CA) of gills of Chasmagnathus granulata (Crustacea Decapoda). Comp. Biochem. Physiol. 127B: 85-95.

Maren, T.H. (1967). Carbonic anhydrase: chemistry, physiology, and inhibition. Amer. Physiol. Soc. 47: 595 - 781.

Markaida, U., Quiñónez-Velásquez, C., and O. Sosa-Nishizaki. (2004). Age, growth, and maturation of jumbo squid, Dosidicus gigas (Cephalopoda: Ommastrephidae) from the Gulf of California, Mexico. Fish. Res. 66: 31 - 27.

Meldrum, N.U. and F.J.W. Roughton. (1933a). Carbonic anhydrase. Its preparation and properties. J. Physiol. 80: $113-142$. 
Meldrum, N.U. and F.J.W. Roughton. (1933b). The state of carbon dioxide in blood. J. Physiol. 80: $143-170$.

Nesis, K.N. (1983). Dosidicus gigas. In: Boyle, P.R. (Ed.), Cephalopod Life Cycles, vol. 1. Species Accounts. Academic Press, London. 216 - 231.

Nigmatullin, Ch.M., Nesis, K.N., and A.I. Arkhipkin. (2001). A review of the biology of the Jumbo squid Dosidicus gigas (Cephalopoda: Ommastrephidae). Fish. Res. 54: $9-19$.

O’Dor, R.K. and D.M. Webber. (1986). The constraints on cephalopods: why squid aren't fish. Can. J. Zool. 64: 1591 - 1605.

O’Dor, R.K. and J.A. Hoar. (2000). Does geometry limit squid growth? ICES J. Mar. Sci. 57: 8 - 14.

Pörtner, H.O. (1994). Coordination of metabolism, acid-base regulation and haemocyanin function in cephalopods. In: Physiology of Cephalopod Molluscs: Lifestyle and Performance Adaptations. Eds. Pörtner, H.O., O’Dor, R.K., and Macmillan, D.L.Gordon and Breach Science Publishers S.A., U.S. pp $131-148$.

Roper, C.F.E. and R.E. Young. (1975). Vertical distribution of pelagic cephalopods. Smithson. Contrib. Zool. 209: 1 - 51.

Roper, C.L., Sweeney, M.J., and C.E. Nauen. (1984). Cephalopods of the World: an annotated and illustrated catalogue of species of interest to fisheries. FAO species catalogue. Vol. 3. FAO Fish. Synop. 125: 227p.

Rosa, R. and B.A. Seibel. (2008). Synergistic effect of climate change-related variables suggests future physiological impairment in a top oceanic predator. Proc. Natl. Acad. Sci. 52: 20776-20780.

Rosa, R. and B.A. Seibel. (2010). Metabolic physiology of the Humboldt squid, Dosidicus gigas: implications for vertical migration in a pronounced oxygen minimum zone. Prog. Oceanogr. 86: 72-80.

Schipp, S., Mollenhauer, S., and S. Boletzky. (1979). Electron microscopical and histochemical studies of differentiation and function of the cephalopod gill (Sepia officinalis L.). Zoomorph. 93: 193-207.

Seibel, B.A., Theusen, E.V., Childress, J.J., and L.A. Gorodezky. (1997). Decline in pelagic cephalopod metabolism with habitat depth reflects differences in locomotory efficiency. Biol. Bull. 192: $262-278$. 
Seibel, B.A. (2007). On the depth and scale of metabolic rate variation: scaling of oxygen consumption rates and enzymatic activity in the class Cephalopoda (Mollusca). J. Exp. Biol. 210: 1 - 11.

Seibel, B.A. (2013). The jumbo squid, Dosidicus gigas (Ommastrephidae), living in oxygen minimum zones II: blood-oxygen binding. Deep-sea Res II 95: $139-144 .$.

Seibel, B.A. and P.J. Walsh. (2003). Biological impacts of deep-sea carbon dioxide injection inferred from indices of physiological performance. J. Exp. Biol. 206: $641-650$.

Seibel, B.A. and P.J. Walsh. (2001). Potential impacts of $\mathrm{CO}_{2}$ injection on deepsea biota. Science. 294: $319-320$.

Serrano, L., Halanych, K.M., and R.P. Henry. (2007). Salinity-stimulated changes in expression and activity of two carbonic anhydrase isoforms in the blue crab Callinectes sapidus. J. Exp. Biol. 210: 2320 - 2332.

Sweeney, A.M., Haddock, S.D., and S. Johnsen. (2007). Comparative visual acuity of coleoid cephalopods. Integr. Comp. Biol. 47: 808-814.

Vecchione, M. (1991). Dissolved oxygen and the distribution of the euryhaline squid Lolliguncula brevis. Bull. Mar. Sci. 49: 668 - 699.

Zool. 62: 1257-1272.

Walsh, P.J. and R.P. Henry. (1991). Carbon dioxide and ammonia metabolism and exchange. In: Biochemistry and molecular biology of fishes vol. 1. P. Hochachka and T. Mommsen eds. Elsevier Science Publishers. pp. 181-207.

Wheatly, M.G. and R.P. Henry, (1992). Extracellular and intracellular acid-base regulation in crustaceans. J. Exp. Zool. 263: 127-142.

Wilke, M.P. (1997). Mechanisms of ammonia excretion across fish gills. Comp. Biochem. Physiol. A: Physiol. 118: 39-50.

Wright, P.A., Randall, D.J., Perry, S.F. (1989). Fish gill water boundary layer: a site of linkage between carbon dioxide and ammonia excretion. J. Comp. Physiol. B. 158: $627-635$.

Yu, Z., Xie, L., Lee, S., and Zhang, R. (2006). A novel carbonic anhydrase from the mantle of the pearl oyster (Pinctada fucata). Comp. Biochem. Physiol. B. 143: $190-194$. 


\title{
CHAPTER 2
}

\section{Carbonic anhydrase activity in pelagic cephalopods from different depths}

\author{
Albert C Nyack* and Brad A. Seibel \\ Department of Biological Sciences, College of the Environmental and Life Sciences, \\ University of Rhode Island, 120 Flagg Road, Kingston, RI 02881-0816 \\ *Author for correspondence (email: nyackac@my.uri.edu)
}

In preparation for submission to:

Marine Biology 


\section{Summary}

Cephalopods are a highly diverse group in terms of habitat distribution, size range, and metabolic rates. Some active, epipelagic species exhibit the highest metabolic rates among animals, once temperature and body mass are accounted for, while meso- and bathypelagic species have very low metabolic rates. A strong decline in mass-specific metabolic rate (MR) with increasing habitat depth has been well documented among pelagic fish and crustaceans. To explain this phenomenon Childress and Mickel (1985) proposed the visual interactions hypothesis, which states that decreasing light levels with increasing depth reduces predator-prey interactions, relaxing selection pressure for strong locomotory ability. This trend is even more pronounced among cephalopod MR and in the oxidative and glycolytic enzymes in this group. Here we further test the visual interactions hypothesis by examining activity of the enzyme carbonic anhydrase (CA) in gills and mantle muscle cephalopods in relation to $\mathrm{MR}$ and habitat depth. CA rapidly catalyzes the hydration/dehydration of $\mathrm{CO}_{2}$, and is thus important to $\mathrm{CO}_{2}$ transport and excretion in animals. The activity of CA is influenced by environmental conditions and may also be related to animal MR. Eleven species of cephalopods ( 9 families) encompassing a mass range over 4 orders of magnitude were fished from coastal waters off southern New England, the coast of California, and in the Sea of Cortez. Protein concentration and total CA activity was measured in mantle muscle and gill tissues, the chief sites of $\mathrm{CO}_{2}$ production and excretion, and analyzed as a function of MR and habitat depth. CA activity was also compared along the length of gills in Doryteuthis pealeii and Mastigoteuthis magna. There was a significant increase in CA activity between each 
gill segment in M. magna and differences between the two species. Total protein concentration in gill tissue decreased with increasing habitat depth over 500-fold. Total CA activity in each tissue showed a direct relationship with MR among species. An inverse relationship with habitat depth was observed, but was only significant in gill tissue. The gills were larger in relation to body mass in the shallower, active squids than from meso- and bathypelagic species. Our results further support the visual interactions hypothesis and show that CA activity is reflective of MR in cephalopods. It also suggests that deep-sea cephalopods may have limited capacity for acid-base regulation, and therefore may be more sensitive to ocean acidification.

Key words: carbonic anhydrase, cephalopods, metabolic rate, ocean acidification, oxygen minimum zones 


\section{Introduction}

The enzyme carbonic anhydrase (CA) is primarily involved in the systemic transport and excretion of $\mathrm{CO}_{2}$ in animals (e.g. Maren, 1967). This enzyme rapidly catalyzes the interconversion of $\mathrm{CO}_{2}$ and water to bicarbonate $\left(\mathrm{HCO}_{3}{ }^{-}\right)$and protons $\left(\mathrm{H}^{+}\right)$. These substrates and products are also important in key homeostatic processes such as acid-base balance, ion transport, and osmoregulation (Dodgson, 1991; Henry and Swenson, 2000; Henry, 2001; Grosell et al., 2007). Thus, CA is also important in intermediary processes and its activity may reflect the metabolic rate $\left(\mathrm{CO}_{2}\right.$ production $)$ of an organism (Henry and Saintsing, 1983; Kochevar and Childress, 1996; Seibel and Walsh, 2003). On the other hand, changes in CA activity or gene expression also respond to ambient environmental conditions, such as salinity (Henry and Cameron, 1982a,b; Grosell et al, 2007), hypoxia (David et al, 2005), and hypercapnia (Georgalis et al, 2006). In invertebrates, the enzyme is concentrated in the gills, the primary site of $\mathrm{CO}_{2}$ excretion and iono- and osmoregulation as opposed to sites of $\mathrm{CO}_{2}$ production (i.e. muscle) (Henry and Cameron, 1982; Henry and Staintsing, 1983; Nyack et al., in prep). Activities are widely reported in gas exchange tissue and appear to be highest in species with high mass-specific metabolic rates (MR), and those living in environments with varying salinities, $\mathrm{O}_{2}$, and $\mathrm{pH}$ levels (Seibel and Walsh, 2003). However, the interspecific correlations between CA activity and either MR or environment have never been systematically tested. This is due, in part, to a focus on animals living near shore and on those most easily obtained.

Animals adapted to the deep-sea typically have lower buffering capacities and fewer ion transport proteins due to their lower metabolic rates (Gibbs and Somero, 
1990; Siebel et al., 1997; Seibel and Walsh, 2003). Among some surface-dwelling squids total CA activity in gill tissue was shown to be independent of size or metabolism (Nyack et al., in prep). However, muscle tissue CA activity was inversely related to size and directly related to MR. The lack of such a relationship in gill tissue may reflect a primary role other than $\mathrm{CO}_{2}$ excretion in loliginid and ommastrephid squids. In both families, however, MR is nearly isometrically related to body mass, and all species exhibit relatively high MR. Thus, the lack of a relationship may be an artifact of the relative similarity of MR among the species tested. Larger variations in MR among cephalopods are observed when examining pelagic species living across a depth range.

Coleoid cephalopods (octopods and squids) are active, predatory mollusks that are widely distributed throughout the marine environment (Roper and Young, 1975; Roper et al., 1984; Vecchione, 1991; Nesis, 2003). However, their predatory habits, and the required locomotory capacity, vary widely between taxa and environments. Most notable, the decreasing light gradient with increasing depth has resulted in diverging lifestyles, locomotory mechanisms, and metabolic capacities. The reported MR among cephalopods appears to bracket the range of such rates among animals. Once temperature and body mass are accounted for, cephalopods exhibit both the greatest (e.g. Doryteuthis pealeii and Dosidicus gigas) and the lowest (Vampyroteuthis infernalis) MR among animals (Seibel et al., 1997; Seibel, 2007). Metabolic rates also correspond to the behaviors and habitat depth of a given species. For example, both $D$. gigas and D. pealeii are very active at the surface while hunting prey and utilize jet propulsion to capture food while simultaneously avoiding being preyed upon (Young, 
1972; Roper and Young, 1975; Macy, 1980; Roper et al., 1984; reviewed in Nigmatullin et al., 2001). At the other end of the cephalopod MR spectrum, $V$. infernalis is bathypelagic $(600-800 \mathrm{~m})$, lives within or below the oxygen minimum layer (1-4 $\left.\mathrm{ml} \mathrm{O}_{2} \cdot \mathrm{L}^{-1}\right)$ and predominantly employs fin swimming (Roper and Young, 1975; Seibel et al., 1998). Obviously the majority of cephalopods exhibit MR between these extremes, and some exhibit adaptations to mitigate energy expenditure. Several midwater species, for example, sequester ammonia in their tissues (Chirotuethids) and coelomic fluid (Cranchids) to aid in buoyancy (Roper and Young, 1975; Voight et al., 1994; Roper and Veccione, 1997; Seibel et al., 2004), thus lowering the energy needed to maintain position in the water column resulting in lower MR.

A strong decline in MR with increasing depth has been well documented among visually-orienting pelagic species distributed in the open ocean (Childress, 1995; Seibel and Drazen, 2007). To explain this phenomenon in fishes and crustaceans, Childress and Mickel (1985) proposed the visual interactions hypothesis, which states that high light levels in shallow water selects for strong locomotory abilities for predator-prey interactions and that such selection is diminished in the dimly lit meso- and bathypelagic depths. Seibel et al., (1997) expanded this hypothesis to include cephalopods, which, like fishes and crustaceans, rely strongly on visual cues. They also reported that metabolic rates among cephalopods declined more rapidly with depth than that of either fishes or crustaceans. They attributed this trend to a reduced use of energetically expensive, high-speed jet propulsion in favor of fin swimming. Likewise, the enzymatic activity of both citrate synthase (CS) and octopine 
dehydrogenase (ODH), indicators of oxidative and glycolytic capacity, respectively, are also negatively correlated with increasing depth (Seibel et al., 2000).

The present study examined the mass-specific activity of CA in mantle muscle and gill, the predominant sites of $\mathrm{CO}_{2}$ production and excretion, respectively, from 11 coleoid cephalopods (9 families) distributed from the surface to $600 \mathrm{~m}$ (minimum depth) (Fig. 1). We further test the visual interactions hypothesis by examining the activity of CA in pelagic cephalopods. We hypothesized that the activity of CA would decline with increasing habitat depth similar to MR and oxidative and glycolytic enzymes (e.g. CS and ODH) (Seibel et al., 1997; 2000). Another purpose was to determine whether CA activities among ecologically diverse cephalopod species reflect the large differences in metabolic rate and their environmental conditions.

\section{Methods}

Animal collection

The Atlantic squid species were captured between September 2008 and November 2009. The majority of Doryteuthis pealeii were caught via otter trawl either aboard the R/V Captain Bert (URI) in Narragansett Bay, RI, or Project Oceanology vessels (University of CT) near New London, CT. Additional D. pealeii were fished off Goat Island, Newport, RI using Japanese-style jigs while. Lolliguncula brevis were caught in creeks near the Virginia Institute of Marine Science Eastern Shore Laboratory, Wachapreague, VA using an otter trawl. Four Mastigoteuthis magna were brought to URI's Graduate School of Oceanography by fishermen trawling $25 \mathrm{~km}$ 

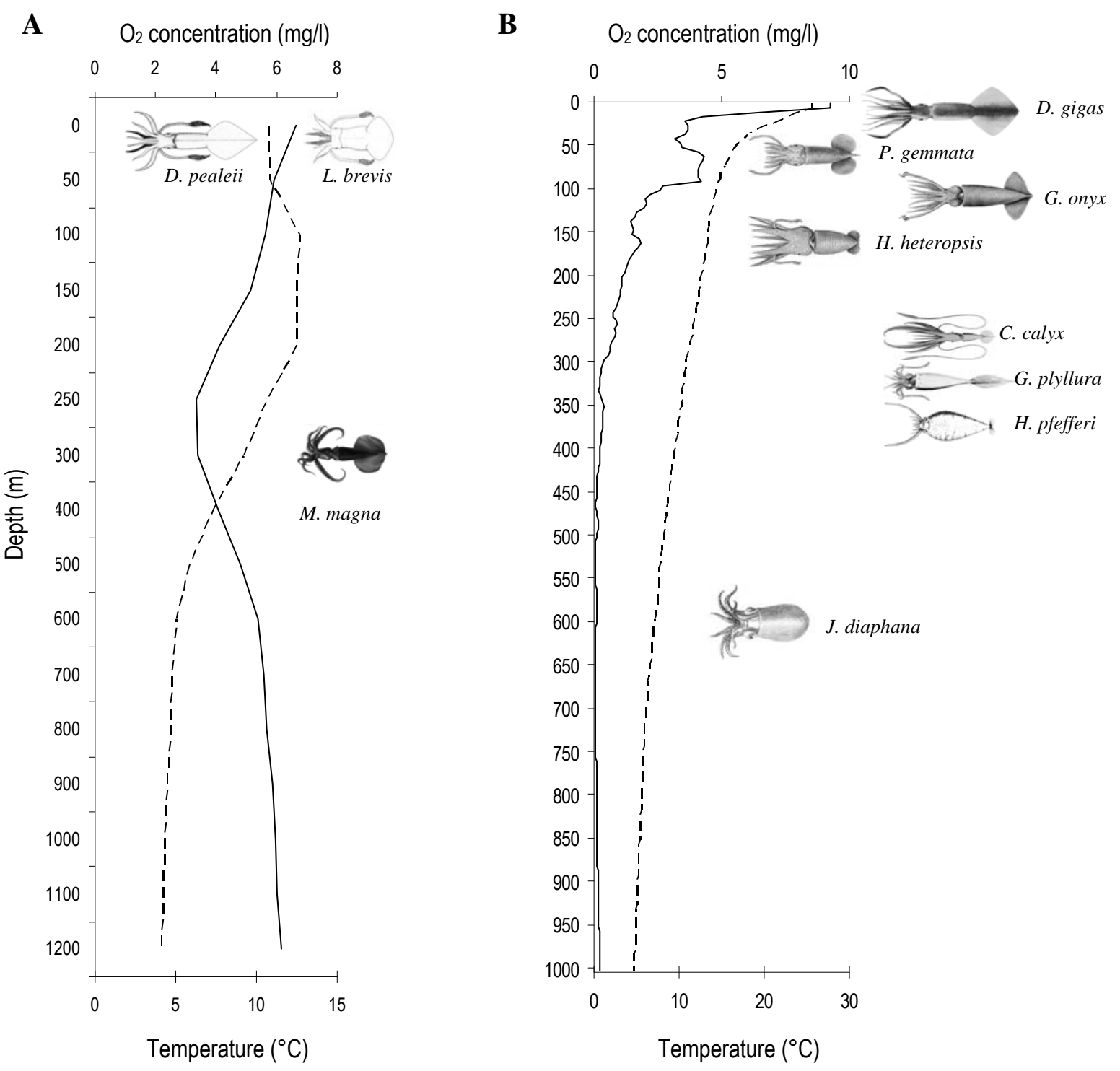

Figure 1. Representative profiles of oxygen concentration (solid lines) and temperature (dashed lines) as a function of depth, and the MDO of squids. A) Oxygen and temperature profiles are from data taken from the $1982 R / V$ Endeavor cruise along $71^{\circ} \mathrm{W}$ (Sta. 14, 39 $\left.46^{\prime} \mathrm{N}, 71^{\circ} 23^{\prime} \mathrm{W}\right)$. This station was located on the shelf $\sim 150 \mathrm{~km}$ south of Block Island, RI. Data was taken from the Java OceanAtlas project (JOA: natl.1982.EV.71W.joa) using the accompanying OceanAtlas program. B) Temperature and $\mathrm{O}_{2}$ profiles from Guaymas Basin $\left(27^{\circ} 15^{\prime} \mathrm{N}, 111^{\circ} 30.4^{\prime} \mathrm{W}\right)$ taken by CTD aboard the $R / V$ New Horizon in 2007. Images of J. diaphana, M. magna, and D. gigas are from public domain sources. All other images were originally from Young, 1972 or Vecchione et al., 1989 and were taken from the Tree of Life web project (http://www.tolweb.org). 
southeast of Block Island, RI aboard the F/V Fishtale at a reported depth of 200 fathoms (366 m). With the exception of M. magna, which were deceased but in good condition and kept on ice until dissection, squids were either dissected immediately or maintained in aerated coolers until dissection.

Cephalopods from the Pacific were caught over the course of several cruises aboard the R/V New Horizon or R/V Western Flyer between May 2006 and September 2011. Three of the five Pterygioteuthis gematta used were caught in May 2006 and the other two in Sept 2011 from the Sea of Cortez aboard the R/V New Horizon. Dosidicus gigas were fished at night using Japanese-style jigs during a June 2011 cruise aboard the R/V New Horizon in the Sea of Cortez, Mexico, and tissues were collected immediately upon landing. Helicocranchia pfefferi was caught using an opening/closing Mother Tucker trawl with a $10 \mathrm{~m}^{2}$ mouth and a $30 \mathrm{~L}$ thermallyprotected cod end (Childress et al., 1978) aboard the R/V Western Flyer in 2009. The remaining species were collected during that same cruise using the ROV Doc Ricketts. Specimens from trawls were allowed to recover from sampling before tissues were excised.

Animal masses were measured for Lolliguncula brevis, D. pealeii, M. magna, and D. gigas prior to tissue dissection. Gill and mantle muscle tissues were excised from Gonatus onyx, Galiteuthis phyllura, Japatella diaphana, and P. gematta, before being fixed in $10 \%$ formalin and preserved in $70 \%$ ethanol. The masses for these species were obtained from the preserved specimens. The masses for three species (Chiroteuthis calyx, Histioteuthis heteropsis, and H. pfefferi) were not obtained. 


\section{Tissue sampling}

The mantle cavity was accessed by a sagittal incision along the ventral surface. Thin, rectangular slices of muscle tissue were excised from the anterior edge of the dorsal mantle and the first $1-2 \mathrm{~cm}$ of gill was sampled from each specimen. Three segments along the length of gill tissue were excised from M. magna for comparison with sections previously examined in D. pealeii (Nyack et al., in prep). These sections were defined as: anterior gill (the first $1 \mathrm{~cm}$ from the anterior tip), middle gill $( \pm 0.5$ $\mathrm{cm}$ from the center of the gill), and posterior gill (the first $1 \mathrm{~cm}$ distal from the branchial heart). All tissue samples were immediately placed into cryo-vials and frozen in liquid nitrogen before being stored at $-80{ }^{\circ} \mathrm{C}$ until use.

\section{Experimental procedures}

Carbonic anhydrase activity was determined in crude homogenates using the $\Delta \mathrm{pH}$ method (Henry, 1991). Frozen tissues were homogenized on ice in 5-30 volumes of assay buffer (in mM: 125 mannitol, 75 sucrose, 10 Tris-base, $\mathrm{pH}=7.4$ ) using glass homogenizers (Kotex, Fisher Scientific). Homogenates were then assayed at $4{ }^{\circ} \mathrm{C}$ in a water-jacketed reaction chamber (Radnoti Glass, Monrovia, CA) that contained $4 \mathrm{ml}$ assay buffer that was continuously stirred. The $\Delta \mathrm{pH}$ was measured every $5 \mathrm{sec}$ for 2 min using a Red Rod pH electrode (Radiometer Analytical) connected to a laptop computer through an Orion $720 \mathrm{~A}^{+}$(Fisher Scientific) meter. Catalyzed reactions were performed in triplicate with the addition of 2.5-40 $\mu$ l of sample while uncatalyzed reactions had corresponding volumes of buffer added. The reaction was initiated by the addition of $80 \mu \mathrm{l} \mathrm{CO}_{2}$-saturated DI. The net reaction rate was calculated by 
subtracting the initial slopes $(\Delta \mathrm{mV} / \mathrm{s})$ of the catalyzed and uncatalyzed reactions. The buffering capacity of the assay buffer was determined by the addition of $80 \mu 1$ of 0.1 $\mathrm{M} \mathrm{HCl}$. This value and the proton contributed from the $\mathrm{HCl}$ were then used to quantify CA activity $\left(\mu\right.$ moles $\left.\mathrm{CO}_{2} \cdot \min ^{-1} \cdot \mathrm{g}^{-1}\right)$. Protein concentration was determined using the Bradford method (1976), and bovine serum albumin was used as standard.

\section{Metabolism and depth}

Carbonic anhydrase activities were compared between gill and muscle both within and among species, as a function of animal mass, and also compared to calculated metabolic rates. The metabolic rates $(Y)$ for species within each family were calculated using the scaling formula $Y=a M^{b}$, where $a$ is a taxon-specific normalization constant specific, $b$ is the scaling coefficient (slope), and $M$ is animal mass. Where body mass was not available, we normalized metabolism to $10 \mathrm{~g}$, a size that is within the commonly captured size range for all species (Seibel, 2007). It has been shown that the majority of variability in metabolism among cephalopods lies between families within an order (as opposed to species within a genus, or genus within a family) (Seibel et al, 2000). Therefore, published temperature-corrected normalization constants and scaling coefficients for cephalopod families (Seibel, 2007) were used to calculate MR for eight of the eleven species (five families). The normalization constants were derived for $P$. gemma, and $M$. magna by utilizing published temperature-corrected MR values (Seibel et al., 1997), an assumed scaling coefficient of -0.2 (Seibel, 2007) and the mean mass for each species. The estimated MR for these two species was then calculated using the actual mass values for each specimen. The 
MR for C. calyx and H. heteropsis was calculated assuming a mass of $10 \mathrm{~g}$ for all specimens in these species, a normalization constant of 0.977 (Seibel et al., 1997) and a scaling exponent of -0.2 (Seibel et al., 1997; Seibel, 2007).

Total CA activity and gill mass (g) (as \% body mass) were also examined as a function of minimum depth of occurrence (MDO). Minimum depth of occurrence is defined as the depth below which $90 \%$ of adult individuals of a species from a given region are captured (Childress, 1975). To maintain consistency with previous studies, and avoid distortions in log-transformed data, $10 \mathrm{~m}$ was used for specimens living at that depth or shallower and for species that undergo diel vertical migrations to the surface (Roper and Young, 1975; Seibel et al., 1997). Minimum depths were taken from several sources (Roper and Young, 1975; Macy, 1980; Wells et al., 1988; Finke et al., 1996; Seibel et al., 1997; Bartol, et al., 2001; Gilly et al., 2006; Seibel et al., 2007) and personal communications (M. magna).

\section{Statistics}

Analysis of variance (ANOVA; $\alpha=0.05$ ) was used to test for differences in protein content and CA activity within tissues among species. When differences were detected, Student's t-test was used to identify differences within the data and also to test for differences in protein content between tissues within each species. Comparisons of CA activity in each gill segment between D. pealeii to M. magna were also analyzed using Student's t-test, and mean values are shown means $\pm \mathrm{sem}$. The relationship between CA activity as a function of MR and MDO were examined using regression analysis. Slopes of regressions were considered significantly different 
from zero at the $95 \%$ confidence level $(\mathrm{P}<0.05)$. Analyses were done using JMP software version 10 (SAS Institute, Cary, NC).

\section{Results}

Carbonic anhydrase activity was measured in gill tissue from nine species and mantle muscle in 11 species of coleoid cephalopods, representing 8 families of Teuthoid squids and an incirrate pelagic octopod, J. diaphana. The MDO among these cephalopods ranged from near surface to $300 \mathrm{~m}$ for the three Atlantic squids sampled (D. pealeii, L. brevis, and M. magna), and to $600 \mathrm{~m}$ Pacific cephalopods (Table 1). The temperature and oxygen ranges over the depths in the regions sampled are presented in Figure 1. The mass range among all cephalopods sampled spanned nearly 4 orders of magnitude. Also represented are species that accumulate ammonium in their tissues for buoyancy (Seibel et al., 2004) from both oceans, and all but two species have been described as exhibiting vertical migratory behavior to greater or lesser degrees.

The protein content in both gill and mantle muscle tissue showed a significant decline with increasing depth ( $\mathrm{P}=0.0017$ and 0.0127 , respectively) (Fig. 2). This trend is similar to that described by Seibel et al., (2004). In gills, the protein concentration ranged from $0.31 \mathrm{mg} \cdot \mathrm{ml}^{-1}$ (J. diaphana) to over 500-times greater in $D$. pealeii $\left(162.89 \mathrm{mg} \cdot \mathrm{ml}^{-1}\right)$. The mean protein content from gill tissue of $D$. pealeii and D. gigas was significantly greater than the protein content in gill tissue of any other species $(\mathrm{P}<0.0001)$. Mantle muscle protein content among species yielded three distinct groupings. The mantle muscle protein concentration for $D$. pealeii and $D$. 
Table 1. Depth, whole animal mass and range, [protein], and ecological some behavioral and physiological features of 11 species of cephalopods. Values are means \pm SEM.

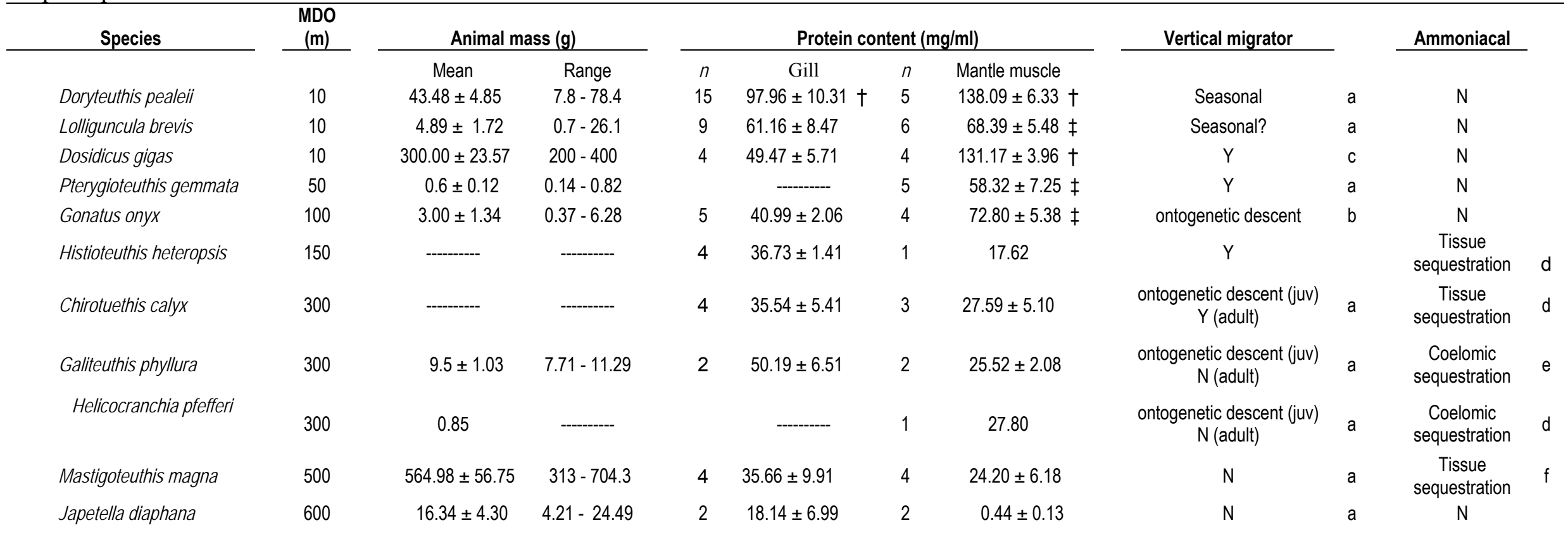

MDO = minimum depth of occurrence

$\dagger=$ significantly greater total protein content than all other species within a given tissue

$\ddagger$ = significantly lower total than those marked with a $\dagger$, but greater than in all other species

Sources: a) Roper and Young, 1975; b) Hunt and Seibel, 2000; c) Gilly et al., 2006, d) Seibel et al., 2004; e) Seibel and Walsh, 2004; f) Voight et al., 1994 


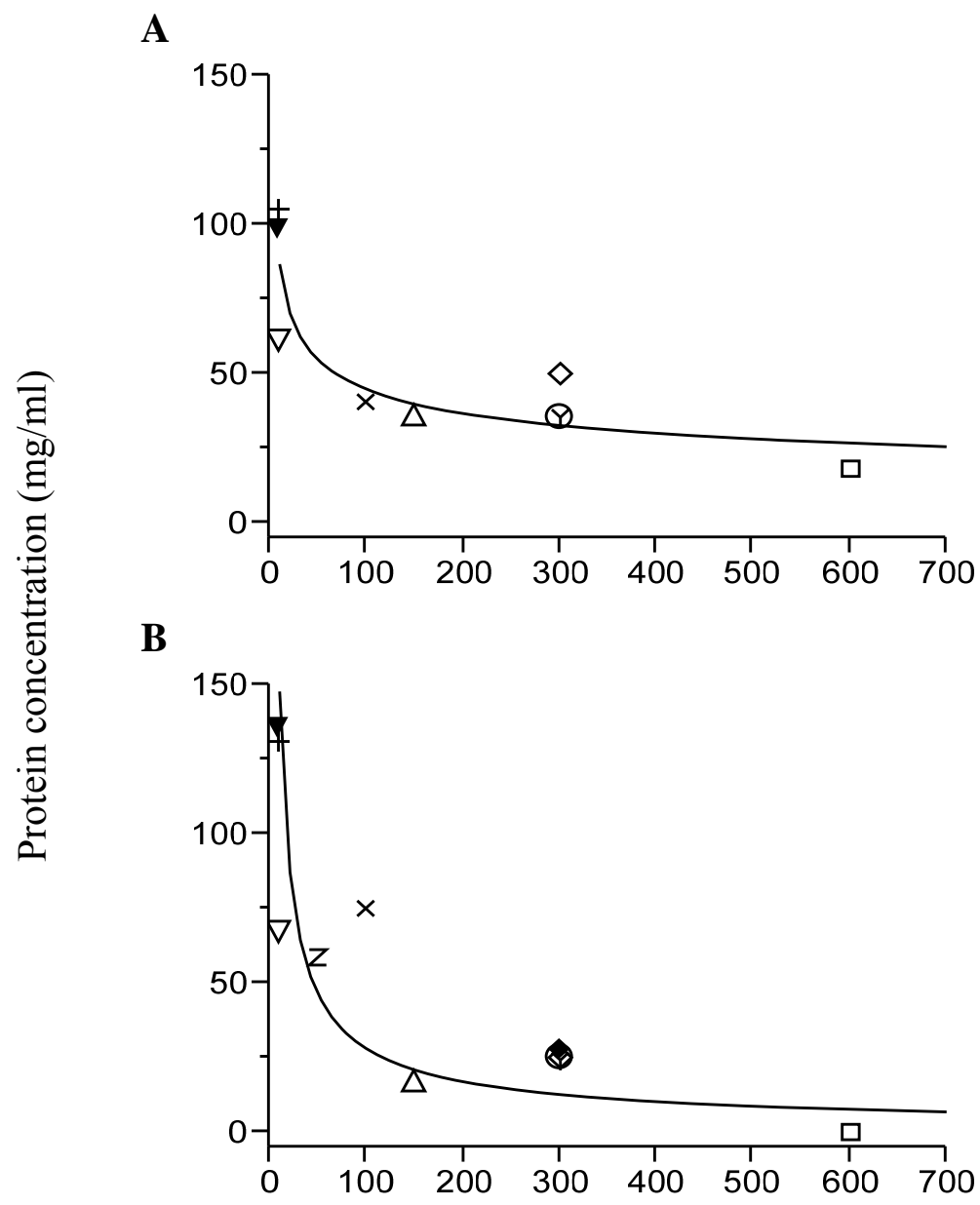

MDO (m)

Figure 2. Protein concentration $(\mathrm{mg} / \mathrm{ml})$ as a function of minimum depth of occurrence (MDO). A) The decline in gill protein with increasing depth was fairly strong significant $\left([\right.$ protein $\left.]=5.13 \mathrm{MDO}^{-0.29}, \mathrm{P}=0.0017, r^{2}=0.78\right) . \mathrm{B}$ ) Mantle muscle protein also declined significantly with increasing MDO $\left([\right.$ protein $\left.]=6.66 \mathrm{MDO}^{0.72}, \mathrm{P}=0.0127, r^{2}=0.52\right)$. Values are means of species. The $n$-values and symbols representing species are listed in table 2.

gigas were each about double the next closest species, G. onyx (Table 1). Three species, L. brevis, P. gemmata, and G. onyx, all of which have MDO $<150 \mathrm{~m}$, had total protein concentrations less than D. pealeii and D. gigas, but greater than the remaining species with $\mathrm{MDO}>150 \mathrm{~m}$. Interestingly, cephalopods residing below 150 m MDO seemed to exhibit a greater amount of protein in the gills than their mantle 
muscle, the opposite of species examined that are shallower than $150 \mathrm{~m}$. However, among species from $>150 \mathrm{~m}$ depth only $M$. magna had sufficient replicates for a statistical comparison in protein content between gill and mantle tissue, but did not show a significant difference $(\mathrm{P}=0.36)$. Among species $<150 \mathrm{~m}$, protein content was significantly greater in the mantle muscle than in the gill tissue of $G$. onyx $(\mathrm{P}=$ $0.0005)$ and D. gigas $(\mathrm{P}<0.0001)$.

\section{CA activity in gill and muscle tissue}

Carbonic anhydrase activity was approximately an order of magnitude greater in gill than in mantle tissue for each species (Table 2). Each of the three "surface species", D. gigas, D. pealeii, and L. brevis, exhibited significantly greater gill CA activity $(\mathrm{P} \leq 0.018)$ compared to the other 6 species examined (Table 2$)$, but were not statistically different from each other. Gill CA activity in C. calyx and M. magna was also not different from each other $(\mathrm{P}=0.37)$, but was in the middle, i.e. significantly lower than the "surface species," and greater than the remaining 4 species $(\mathrm{P} \leq 0.028)$, (Table 2). Mantle muscle CA activity was significantly greater in both L. brevis and P. gemmata compared to all other species $(\mathrm{P} \leq 0.026)$, but not statistically different from each other $(\mathrm{P}=0.37)$ (Table 2$)$.

Gill CA activity from three sections along the length of gill in M. magna was compared to activity along the length of D. pealeii (Nyack et al., in prep) (Fig 3). Mean CA activity in D. pealeii ranged $6000-9000 \mu \mathrm{mol} \mathrm{CO}_{2} \cdot \mathrm{g}^{-1} \cdot \mathrm{min}^{-1}(\mathrm{n}=4-6)$, and were not significantly different from each other (ANOVA, $\mathrm{P}=0.1696$ ). In $M$. magna, each section was significantly different from the others (ANOVA, $\mathrm{P}=0.0006$ ) and 
Table 2. Calculated mass-specific metabolic rates (MR), CA activity, and specific CA activity from gill and muscle tissue. Values are means \pm SEM.

\begin{tabular}{|c|c|c|c|c|c|c|}
\hline \multirow[t]{2}{*}{ Species } & \multirow[t]{2}{*}{ Symbol } & \multirow[t]{2}{*}{$\operatorname{MR}\left(\mu \mathrm{mol} \mathrm{O} \mathrm{O}_{2} \cdot \mathrm{g}^{-1} \cdot \mathrm{h}^{-1}\right)$} & \multicolumn{4}{|c|}{ CA activity $\left(\mu \mathrm{mol} \mathrm{CO} 2 \cdot \mathrm{g}^{-1} \cdot \mathrm{min}^{-1}\right)$} \\
\hline & & & $n$ & Gill & $n$ & Mantle muscle \\
\hline D. pealeii & $\nabla$ & $6.07 \pm 0.08$ & 15 & $8294.06 \pm 716.56 \dagger$ & 4 & $317.76 \pm 128.31$ \\
\hline D. gigas & + & $4.91 \pm 0.03$ & 5 & $8683.65 \pm 403.1 \quad \dagger$ & 4 & $216.8 \pm 42.79$ \\
\hline P. gemmata & Z & $4.95 \pm 0.35$ & --- & ------- & 5 & $848.76 \pm 130.44 \dagger$ \\
\hline G. onyx & $X$ & $4.39 \pm 0.07$ & 5 & $3008.86 \pm 527.42$ & 3 & $235.68 \pm 17.59$ \\
\hline C. calyx & $\mathrm{O}$ & 0.62 & 4 & $4898.17 \pm 836.89 \ddagger$ & 2 & $253.27 \pm 132.14$ \\
\hline G. phyllura & $\diamond$ & $0.35 \pm 0.01$ & 2 & $1791.04 \pm 206.24$ & 2 & $135.69 \pm 32.56$ \\
\hline M. magna & $\mathrm{Y}$ & $0.60 \pm 0.02$ & 4 & $5202.05 \pm 763.64 \ddagger$ & 4 & $95.2 \pm 27.88$ \\
\hline H. pfefferi & $\diamond$ & 0.55 & --- & ------- & 1 & 108.55 \\
\hline J. diaphana & $\square$ & $0.14 \pm 0.02$ & 2 & $1238.47 \pm 126.98$ & 2 & $313.83 \pm 60.56$ \\
\hline
\end{tabular}

$\dagger=$ significantly greater CA activity compared to all other species within a given tissue

$\ddagger=$ significantly lower gill CA activity than those marked with a $\dagger$, but greater than activity in all other species 
ranged from $3000-7500 \mu \mathrm{mol} \mathrm{CO} 2 \cdot \mathrm{g}^{-1} \cdot \min ^{-1}(\mathrm{n}=4$ in all assays). Between the two species, the CA activity in the anterior and mid-gill sections were significantly greater in $D$. pealeii than in M. magna $(\mathrm{P}=0.0287 ; 0.0017$, respectively), but not in the posterior gill $(\mathrm{P}=0.3966)$.

\section{CA activity and $M R$}

Figure 4 shows the relationship between CA activity and MR. Gill CA activity increased significantly as species $\mathrm{MR}$ increased $(\mathrm{CA}$ activity $=831.97 \mathrm{MR}+2371.97, \mathrm{P}$ $=0.0157, r^{2}=0.589$, Fig. 4A). Among cephalopods, one unit change in MR corresponds to nearly a 1000 unit increase in gill CA activity. There was also a significant relationship between CA activity in mantle muscle and MR (CA activity $=$ 57.36MR+163.93, $\mathrm{P}=0.0324, r^{2}=0.415$, Fig. 4B).

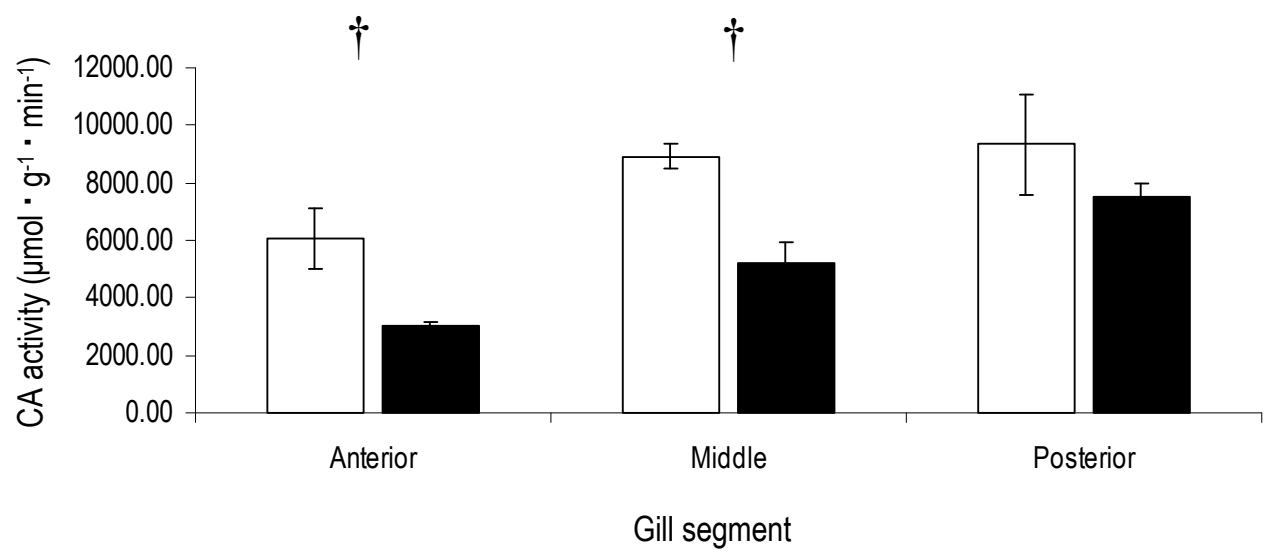

Figure 3. Carbonic anhydrase activity measured in three 1-2 $\mathrm{cm}$ segments of gill tissue from $D$. pealeii (white) and M. magna (black). There were significant differences in anterior and middle gills $\mathrm{CA}$ activity between the two species $(\mathrm{P}=$ 0.0287 and 0.0017 , respectively) (denoted by $\dagger$ ). Activity of each segment from $M$. magna was significantly different from each other $(\mathrm{P}=0.0006)$. Values are means \pm SEM 


\section{$C A$ in gill and muscle tissues with $M D O$}

A strong, significant decline in CA activity with increasing minimum depth of occurrence was observed in gill tissue $(\mathrm{P}=0.0332$, Fig. 5A). The slope for gill $\mathrm{CA}$

A

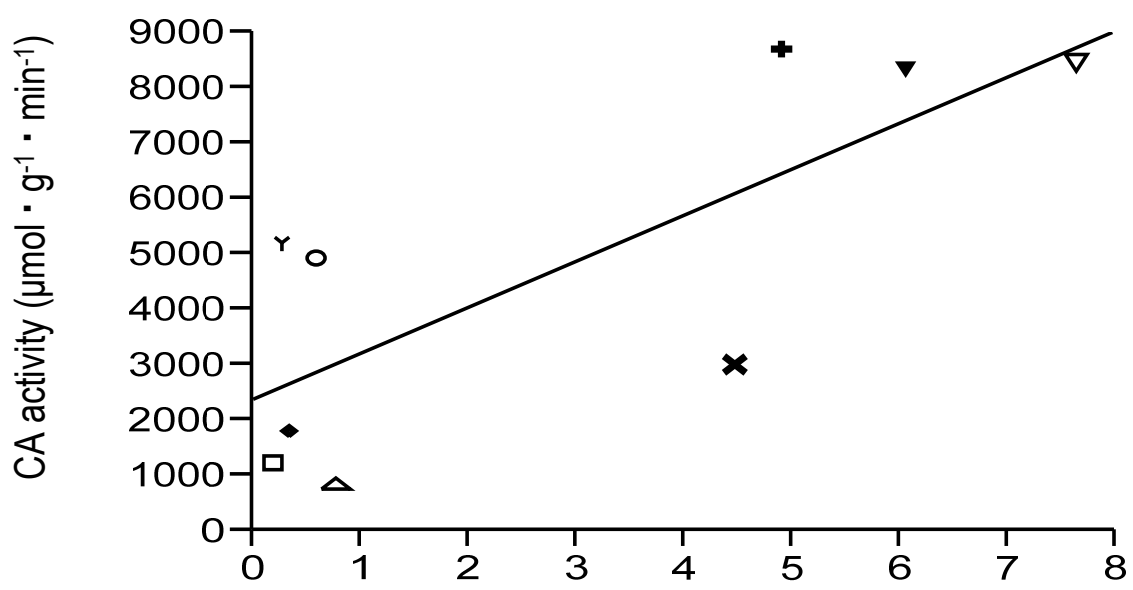

B

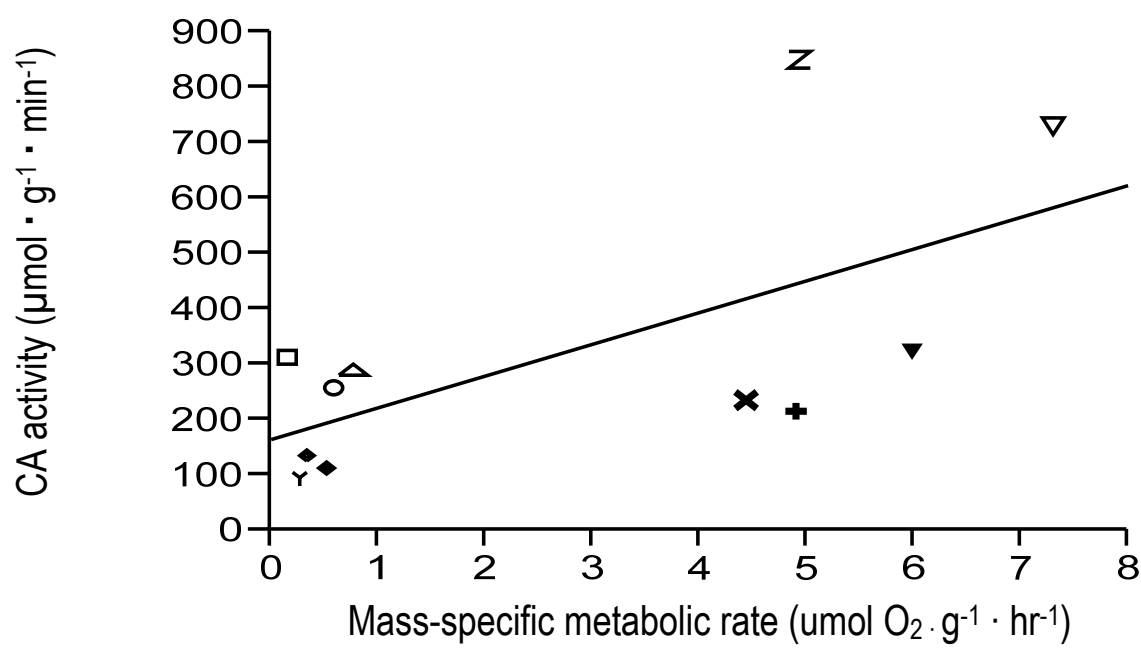

Figure 4. Mean calculated mass-specific metabolic rate for each individual species. A) Gill CA activity is significantly correlated with mass-specific metabolic rate $\left(\mathrm{CA}\right.$ activity $\left.=826.24 \mathrm{MR}+2359.57, \mathrm{P}=0.0148, r^{2}=0.60\right)$. B) Muscle CA activity was also significantly correlated (CA activity = 57.36MR+163.93, $\left.\mathrm{P}=0.0324, r^{2}=0.415\right)$ among all species. Symbols representing each species are in Table 2. 
activity versus MDO was $b=-0.37( \pm 0.14)$, and $b=-0.32( \pm 0.18)$ for mantle muscle CA activity. However, despite the similar slopes, CA activity in cephalopod mantle muscle was not significantly correlated with $\mathrm{MDO}(\mathrm{P}=0.0974$, Fig 5B). This may be due to low CA activity in mantle muscle of D. gigas (Nyack et al., in prep). The activity of $\mathrm{CA}$ as a function of MDO in both tissues was much less than the slopes exponents for CS and ODH (Seibel et al., 2000).

The gill tissue mass (as \% body mass) measured in 9 representative species is plotted as a function of MDO (Fig 6). Four species, P. gemmata, M. magna, Grimaulditeuthis spp., and Planktoteuthis spp. are represented by a single specimen. Gill mass decreased significantly with increasing depth $\left(\mathrm{P}=0.0384, r^{2}=0.54\right)$, similar to trends observed by others (Seibel et al., 2004).

\section{Discussion}

In agreement with previous findings that metabolism of pelagic animals declines with habitat depth, we demonstrate an inverse relationship between CA activity in cephalopod gill tissue and the MDO for each species and a positive correlation between CA activity and MR. The direct relationship between CA activity and MR in gill tissue strongly suggests that the primary role of CA in squid gill tissue is $\mathrm{CO}_{2}$ excretion. Metabolic rates in shallow-living species are among the highest in the animal kingdom, higher than scombrid fishes and even mammals once corrected for differences in temperature (Seibel and Drazen, 2007). This is especially true at larger sizes because metabolism scales with a much shallower slope $(b=0.1)$ in 
A

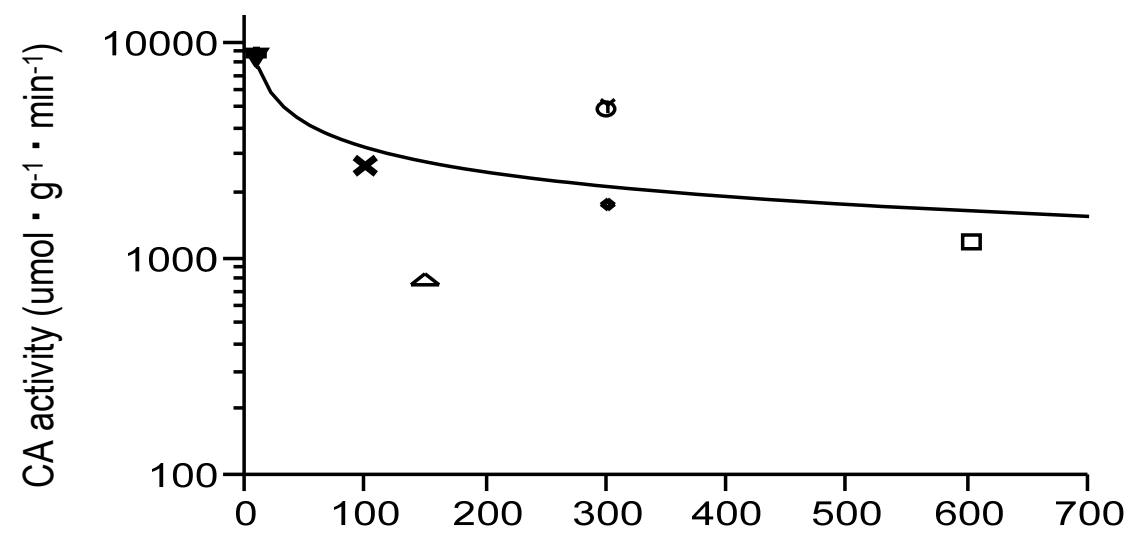

B

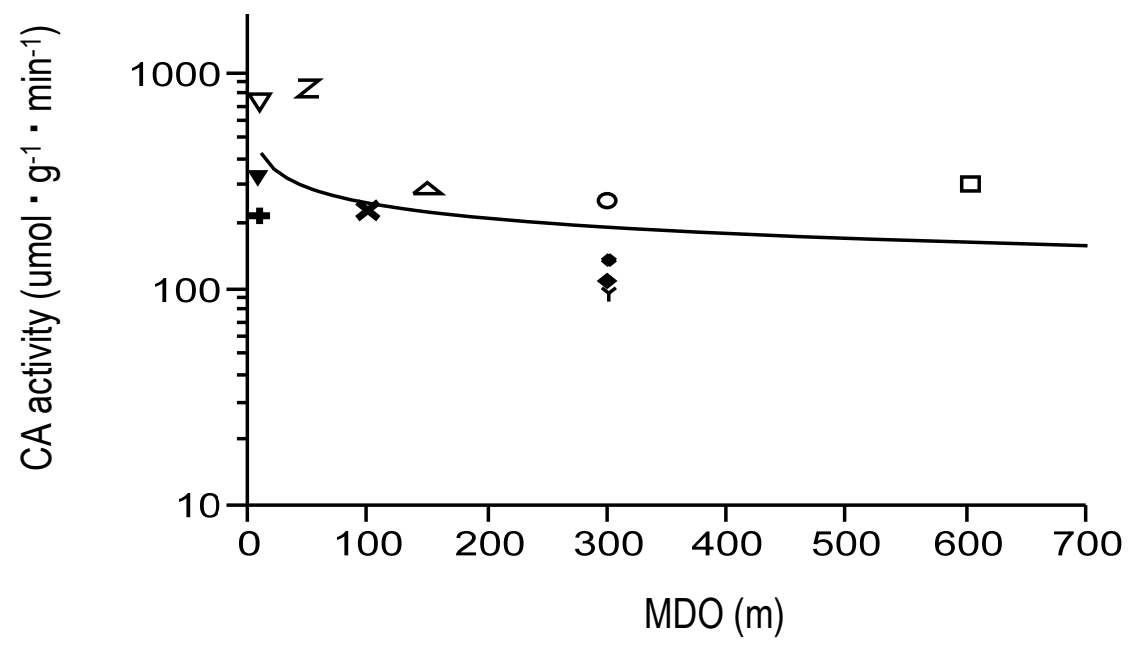

Figure 5. Carbonic anhydrase activity as a function of MDO for A) gill and B) muscle. The slope for the regression in gill (A) is described by $\mathrm{CA}$ activity = $9.83 \mathrm{MDO}^{-0.37}$ and was significant $\left(\mathrm{P}=0.0332, \mathrm{R}^{2}=0.50\right)$. For mantle muscle (B) the relationship between activity and MDO is CA activity $=6.60 \mathrm{MDO}^{-0.23}$ but was not found to be significant $\left(\mathrm{P}=0.0974, \mathrm{R}^{2}=0.276\right)$. The symbols for each species are in Table 2.

epipelagic cephalopods than in either fishes or mammals (Seibel, 2007; Rosa et al., 2009). Interestingly, total CA activities in these squid families, while higher than deep-living cephalopods, are generally lower than that in fishes (Henry, et al., 1988; Maffia et al., 2001; Gilmour et al., 2002; Nyack et al., in prep). This is likely due to differences in osmoregulation in these groups. One of the roles for $\mathrm{CA}$ in the gill 
tissue of marine fishes is to provide counter ions for $\mathrm{Na}^{+}$and $\mathrm{Cl}^{-}$, and thereby water uptake (reviewed by Gilmour, 2012). Since squids are isosmotic to seawater they would not need gill CA in this context. Mantle in squids may be as multifunctional as gill tissue. As much as $90 \%$ of a squid's oxygen demand has been proposed to occur

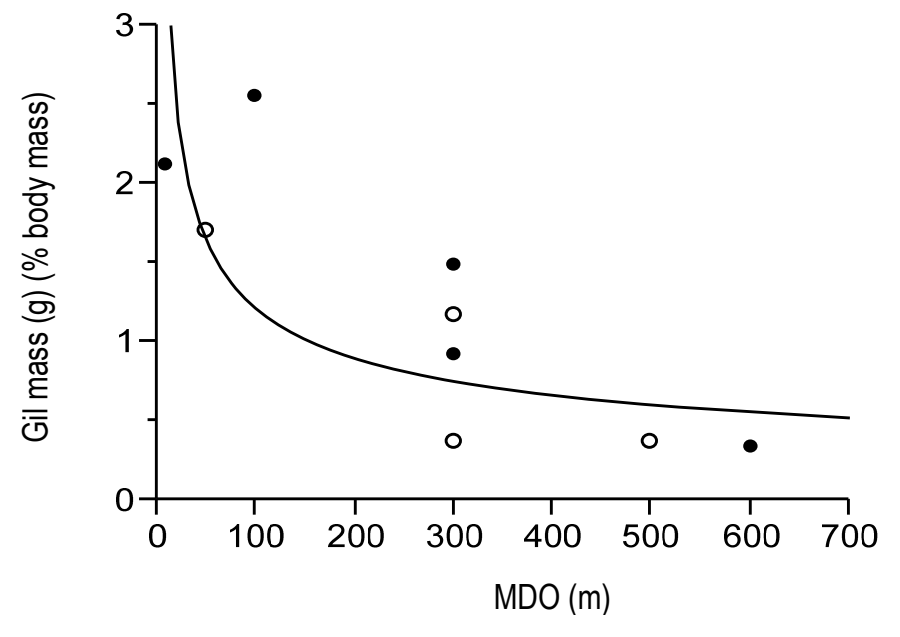

Figure 6. Mean gill mass in relation to MDO of some representative squid species. The regression line is described by the equation gill mass $=2.11 \mathrm{MDO}^{-0.4}\left(\mathrm{P}=0.0384, r^{2}=0.54\right)$. Closed points represent means of $n=2-9$ species, open circles $n=1$.

across the mantle (Portner, 1994). If mantle muscle tissue also acts as an osmoregulatory organ it may explain the high CA activity found in L. brevis, the only squid to inhabit estuarine waters (Hendrix, et al., 1981; Bartol et al., 2001 2002). The reason for the high activity in $P$. gemmata mantle tissue is unclear.

Regardless, the reduction in CA activity with depth is pronounced and deepliving species have activities similar to other deep-sea species from stable environments (Seibel and Walsh, 2003). This 10-fold reduction in CA activity is much less than previously reported for either whole-animal metabolism or the 
concentrations of metabolic enzymes in muscle tissue (Seibel et al., 1997; 2000). The relatively shallow decline in CA activity is partly explained by differences in total gill size in deep- and shallow-living species. We found that both gill mass and protein concentration declines strongly with depth. Active squids tend to have very high gill surface areas and enlarged gills that presumably enhance oxygen and $\mathrm{CO}_{2}$ exchange on a whole-animal basis (Eno, 1994), while more sluggish species have smaller gills and lower gill surface areas (Madan and Wells, 1996, but see below for adaptations to the oxygen minimum zone). The higher protein concentration in gill tissue, combined with the higher gill CA activities, suggests portion of the difference is likely due to more enzyme in the gills of shallow living species. Interestingly, there was no correlation between metabolic rate and specific activity of $\mathrm{CA}\left(\mu \mathrm{mol} \mathrm{CO}_{2} \cdot \mathrm{mg}\right.$ protein $^{-1} \cdot \min ^{-1}$ ) among squids (Nyack, $\mathrm{PhD}$ dissertation $\left.\mathrm{Ch} 3\right)$. Thus, total CA activity in gills of shallow species may exceed that in deep-living species by much more than is apparent in the tissue mass-specific activities reported here.

Another difference in gill CA between epi- and mesopelagic squids is illustrated by the differences CA activity along the length of the gills in D. pealeii and M. magna. In D. pealeii higher activity in the middle and posterior gill segments was largely due to a significant increase in the activity from the mitochondrial subcellular fraction (Nyack et al., in prep). The reason for the different activities between gill segments within M. magna cannot be ascribed using crude homogenate, the only measurement done here. However, the difference in CA activity in anterior and middle gill between the two species can be explained by the relationship between CA activity and MR. D. pealeii are actively swimming, surface squids whereas M. magna is a 
neutrally buoyant species that 'hovers' in a tuning-fork shape with tentacles dangling in the water column (Roper and Veccione, 1998). The trend of increasing CA along the gills in both species is less clear. Squid have a closed circulatory system with highly folded gill lamellae that are profused by primary, secondary, and tertiary afferent and efferent vessels (Shipp et al., 1979). In many species the gills taper towards the anterior end of the mantle cavity (pers. obs.). The high CA activity in posterior gill segments (proximal to the branchial heart) of both species may be required to facilitate rapid $\mathrm{CO}_{2}$ excretion as the bulk of deoxygenated blood enters the gill.

Many of the species studied were captured in the Eastern Pacific where a strong oxygen minimum zone exists at intermediate depths. Such zones are characterized by oxygen levels less than $5 \%$ air saturation and high $\mathrm{CO}_{2}$ levels leading to $\mathrm{pH}$ levels less than 7.6. It may be that the more modest decline in CA activity with depth reflects an increased requirement for $\mathrm{CA}$ activity to facilitate $\mathrm{CO}_{2}$ excretion against a relatively low gradient from the blood to seawater. However, the relatively high activity found for M. magna and C. calyx compared to other species at or below the MDO for these species would argue against this possibility. The similarity in CA activity between these two species may be due to phylogeny rather than habitat since both species belong to the Chiroteuthis clade. The M. magna we used were fished from $300 \mathrm{~m}$, but this species has been observed at depths of $>500 \mathrm{~m}$ (Roper and Veccione, 1997). The waters of the Atlantic are characterized as well-oxygenated at these intermediate depths, especially compared to the same depths in the eastern Pacific and Gulf of California (Fig. 1). Furthermore, species permanently inhabiting oxygen minimum zones tend to have high gill surface areas that may compensate $\mathrm{CO}_{2}$ 
excretion (Friedman et al., 2012; Childress and Seibel, 1998; Seibel and Childress, 1996; Roper, 1969). In fact, gill surface areas per unit gill mass in deep-living species from oxygen minimum zones approach those in active surface species, although the gills themselves are much smaller (Madan and Wells, 1996).

Recent attention to CA activity stems from an expectation of its importance in acid-base balance and $\mathrm{CO} 2$ excretion in waters that are becoming increasingly acidified due to anthropogenic carbon dioxide pollution. Ocean acidification is expected to result in an average decline in oceanic $\mathrm{pH}$ of about 0.3 units by the year 2100 (Seibel and Fabry, 2003). Seibel and Walsh (2001) hypothesized that species with high metabolic rates may be more tolerant of ocean acidification because they are naturally equipped with a high capacity for acid-base balance that is required to deal with metabolically produced $\mathrm{CO}_{2}$ and proton equivalents. This hypothesis has received some support (Pane and Barry, 2007; Melzner et al., 2009) and the relationship shown here between CA activity and metabolic rate adds further support for that hypothesis. However, squids are nonetheless expected to be sensitive to high $\mathrm{CO}_{2}$ due to an extremely pH-sensitive oxygen transport protein (Seibel, 2013; Pörtner, 2002). In fact, Rosa and Seibel (2008) demonstrated that the epipelagic squid, D. gigas, has a reduced metabolic capacity under high $\mathrm{CO}_{2}$ conditions.

The decline with depth in CA activity in gill is hypothesized here to reflect the metabolic rate in deep- and shallow-living organisms. Metabolism is lower in deepliving species as a result of relaxed selection for strong locomotory abilities in the light-limited deep-sea (Seibel and Drazen, 2007; Childress, 1995). This "visual interactions hypothesis" is supported by the presence of strong declines in metabolism 
with depth in pelagic, visually-orienting groups, such as fishes, crustaceans and cephalopods. Such groups lack refuge from predators in well-lit surface waters and have evolved high locomotory capacity that facilitates predator avoidance and prey capture. In the deep-sea, such selection is reduced as visual taxa rely on sit-and-wait predation strategies. Deep-sea pelagic species tend to be neutrally buoyant, sluggish swimmers with high water content and low protein content in muscles. In contrast, non-visual groups, such as jellyfishes, pteropod mollusks, chaetognaths, and copepods, tend to have low, albeit variable, metabolic rates regardless of habitat depth (Seibel and Drazen, 2007; Childress, 1995). Similarly, benthic representatives of sighted-taxa have greater opportunities for refuge and crypsis and so their metabolic rates are largely independent of habitat depth (Seibel and Drazen, 2007). Other hypotheses that have been put forward to explain the decline in metabolism with depth, including oxygen limitation, temperature, food-limitation and high hydrostatic pressure, have largely been refuted by comparative studies showing that declines in metabolism with depth are found in all regions but not all taxa (Childress, 1995; Seibel and Drazen, 2007). Thus the visual interactions hypothesis has been thoroughly tested over several decades and the present contribution may have more value as a test of the relationship between CA activity and metabolism than between metabolism and depth.

\section{Conclusions}

CA activity was greater in gill tissue than in mantle muscle tissue from all cephalopods in this study, and the total protein concentration in both tissues showed a strong decline with increasing MDO. Shallow, more active squids had greater CA 
activity in both tissues than meso- and bathypelagic cephalopods, indicating that metabolic rate appears to be a driving factor in CA activity among these animals. Both gill CA activity and the size of cephalopod gills relative to body mass decreased strongly with increasing depth. There was some evidence showing CA activity changes anterior-posteriorally in some species; however the reason underlying this trend is not yet clear.

\section{Acknowledgements}

Thank you to L. Elder, S. Bush, A. Maas, and T. Towanda for helping to collect specimens and to the crews of the R/V Western Flyer and R/V New Horizon. 


\section{Literature cited}

Bartol, I.K., Mann, R., and M..R. Patterson. (2001). Aerobic respiratory costs of swimming in the negatively buoyant brief squid, Lolliguncula brevis. J. Exp. Biol. 204: 3639-3653.

Bartol, I.K., Mann, R., and Vecchione, M. (2002). Distribution of the euryhaline squid Lolliguncula brevis in Chesapeake bay: effects of selected abiotic factors.Mar. Ecol. Prog. Ser. 226: 235 - 247.

Belman, B. (1978). Respiration and the effects of pressure on the mesopelagic vertically migrating squid Histioteuthis heteropsis. Limno. Oceano. 23: 735739.

Bradford, M.M. (1976). A rapid and sensitive method for the quantification of microgran quantities of protein-dye binding. Anal. Biochem. 72: 248-254.

Childress, J.J. (1975). The respiratory rates of midwater crustaceans as a function of depth occurrence and relation to the oxygen minimum layer off Southern California. Comp. Biochem. Physiol. 50A: 787-799.

Childress, J.J. (1995). Are there physiological and biochemical adaptations of metabolism in deep-sea animals? Trends Ecol. Evol. 10: 30-36.

Childress, J.J. and T.J. Mickel. (1985). Metabolic rates of animals from the hydrothermal vents and other deep-sea habitats. Biol. Soc. Wash. Bull. 6: 249260.

Childress, J.J., and B.A. Seibel. (1998). Life at stable low oxygen levels: adaptations of animals to oceanic oxygen minimum layers. J. Exp. Biol. 201: 1223-1232.

Childress, J.J., Barnes, A.T., Quetin, L.B., and B.H. Robison. (1978). Thermally protecting cod ends for recovery of living deep-sea animals. Deep-sea Res. 25: 419-422.

David, E., Tanguy, A., Pinchavant, K., and D. Moraga. (2005). Response of the Pacific oyster Crassostrea gigas to hypoxia exposure under environmental conditions. Fed. Euro. Biochem. Soc. J. 272: 5635-5652.

Dodgson, S.J. (1991). The carbonic anhydrases: Overview of their importance in cellular physiology and in molecular genetics. In: The Carbonic Anhydrases: Cellular, Phyiology, and Molecular Genetics (eds. S.J. Dodgson, R.E. Tashian, G. Gros and N.D. Carter), New York: Plenum. pp. 3-14. 
Eno, N.C. (1994). The morphometrics of cephalopod gills. J. Mar. Biol. Assn. U.K. 74: 687-706.

Finke, E., Pörnter, H. O., Lee, P.G., and D.M. Webber. (1996). Squid (Lolliguncula brevis) life in shallow waters: oxygen limitation of metabolism and swimming performance. J. Exp. Biol. 199: 911-921.

Friedman, J.R., Condon, N.E., and J.C. Drazen. (2012). Gill surface area and metabolic enzyme activities of demersal fishes associated with the oxygen minimum zone off California. Limnol. Oceanogr. 57: 1701-1710.

Georgalis, T, Perry, S.F., and K.M. Gilmour. (2006). The role of branchial carbonic anhydrase in acid-base regulation in rainbow trout (Onchorhynchus mykiss). J. Exp. Biol. 209: 518-530.

Gibbs, A., and G. Somero. (1990). $\mathrm{Na}^{+}-\mathrm{K}^{+}$-adenosine triphosphate activities in gills of marine teleost fishes: changes with depth, size and locomotory activity level. Mar. Biol. 106: 315-321.

Gilmour, K.M., (2012). New insights into the many functions of carbonic anhydrase in fish gills. Respir. Physiol. Neurobiol. 184: 223-230.

Gilmour, K.M., Shah, B., and C. Szebedinsky. (2002). An investigation of carbonic anhydrase activity in the gills and blood plasma of brown bullhead (Ameiurus nebulosus), longnose skate (Raja rhina), and spotted ratfish (Hydrolagus colliei). J. Comp. Physiol. 172B: 77-86.

Gilly, W.F., Markaida, U., Baxter, C.H., Block, B.A., Boustany, A., Zeidberg, L., Reisenbichler, K., Robison, B., Bazzino, G., and C. Salinas, (2006). Vertical and horizontal migrations by the jumbo squid Dosidicus gigas revealed by electronic tagging. Mar. Ecol. Prog. Ser. 324: 1 - 17.

Grosell, M., Gilmour, K.M., and S.F. Perry (2007). Intestinal carbonic anhydrase, bicarbonate, and proton carriers play a role in the acclimation of rainbow trout to seawater. Am. J. Physiol. 293: R2099 - R2111.

Hendrix, J.P., Hulet, W.H., and M.J. Greenberg. (1981). Salinity tolerance and the response to hypoosmotic stress of the bay squid Lolliguncula brevis, a euryhaline cephalopod mollusc. Comp. Biochem. Physiol. A 69: 641-648.

Henry, R.P. (1991). Techniques for measuring carbonic anhydrase activity in vitro: The electrometric delta $\mathrm{pH}$ method and the $\mathrm{pH}$ stat method. In: The Carbonic Anhydrases: Cellular, Phyiology, and Molecular Genetics (eds. S.J. Dodgson, R.E., Tashian, G., Gros and N.D. Carter), New York: Plenum. pp. $119-125$. 
Henry, R.P. (1996). Multiple roles of carbonic anhydrase in cellular transport and metabolism. Ann. Rev. Physiol. 58: 523-538.

Henry, R.P. (2001). Environmentally mediated carbonic anhydrase induction in the gills of euryhaline crustaceans. J. Exp. Biol. 204: 991 - 1002.

Henry, R.P. and D.G. Saintsing. (1983). Carbonic anhydrase activity and ion reglation in three species of osmoregulating bivalve molluscs. J. Physiol. Zool. 56: $274-280$.

Henry, R.P. and J.N. Cameron. (1982a). Acid-base balance in Callinectes sapidus during acclimation from high to low salinity. J. Exp. Biol. 221: 309-321.

Henry, R.P. and J.N. Cameron. (1982b). The distribution and partial characterization of carbonic anhydrase in selected aquatic and terrestrial decapod crustaceans. J. Exp Zool. 221: 309-321.

Henry, R.P. and E.R. Swenson. (2000). The distribution and physiological significance of carbonic anhydrase in vertebrate gas exchange organs. Respir. Physiol. 121: 1 - 12 .

Henry, R.P., Smatresk, N.J., and J.N. Camerson. (1988). The distribution of brachial carbonic anhydrase and the effects of gill and erythrocyte carbonic anhydrase inhibition in the channel catfish Ictalurus punctatus. J. Exp. Biol. 134: 201-218.

Hunt, J.C., and B.A. Seibel. (2000). Life history of Gonatus onyx (Cephalopoda: Teuthiodea): ontogenetic changes in habitat, behavior and physiology. Mar. Biol. 136: 543-552.

Kochevar, R.E. and J.J. Childress. (1996). Carbonic anhydrase in deep-sea chemoautotrophic symbioses. Mar. Biol. 125: 375-383.

Macy, W.K. (1980). The ecology of the common squid Loligo pealei Lesueur, 1821 in Rhode Island waters. PhD thesis, URI, 230pp.

Madan, J.J and M.J. Wells. (1996). Why squid can breathe easier. Nature 380: 590.

Maffia, M., Rizzello, A., Acierno, R., Rollo, M., Chiloiro, R., and C. Storelli. (2001). Carbonic anhydrase activity in the tissues of the icefish Chionodraco hamatus and of the red-blooded teleosts Trematomus bernachii and Anguilla angilla. J. Exp. Biol. 204: 3983-3992.

Maren, T.H. (1967).Carbonic anhydrase: chemistry, physiology, and inhibition. Physiol. Rev. 47: 595-581. 
Melzner, F., Gutowska, M.A., Langenbuch, M., Dupont, S., Lucassen, M., Throndyke, M.C., Bleich, M., and H.O. Pörtner. (2009). Physiological basis for high $\mathrm{CO}_{2}$ tolerance in marine ectothermic animals: pre-adaptation through lifestyle and ontogeny? Biogeosci. 6: 2313-2331.

Nesis, K.N. (2003). Distribution of recent Cephalopoda and implications for PlioPleistocene events. In: Coleoid cephalopods through time (K. Warnke, H. Keupp, and S. Boletzky eds.). Ber. Parabiol. Abh. 3: 199-224.

Nigmatullin, C.M., Nesis, K.N., and A.I. Arkhipkin. (2001). A review of the biology of the jumbo squid Dosidicus gigas (Cephalopoda: Ommastrephidae). Fish. Res. 54: 9-19.

Nyack, A.C., Henry, R.P., and B.A. Seibel. (in prep). Characterization of carbonic anhydrase activity from squid gills and mantle tissue. PhD dissertation. University of Rhode Island, 2013.

Pane, E.F. and J.P. Barry. (2007). Extracellular acid-base regulation during shortterm hypercapnia is effective in a shallow-water crab, but ineffective in a deepsea crab. Mar. Ecol. Prog. Ser. 334: 1-9.

Pörtner, H.O. (1994). Coordination of metabolism, acid-base regulation and haemocyanin function in cephalopods. In: Physiology of Cephalopod Molluscs: Lifestyle and Performance Adaptations. Eds. Pörtner, H.O., O’Dor, R.K., and Macmillan, D.L.Gordon and Breach Science Publishers S.A., U.S. pp $131-148$.

Pörtner, H.O. (2002). Environmental and functional limits to muscular exercise and body size in marine invertebrate athletes. Comp. Biochem. Physiol. 133A: 303-321.

Roper, C.F.E. (1969). Systematics and zoogeography of the worldwide bathypelagic squid Bathyteuthis (Cephalopoda: Oegopsida). U.S. Nat. Mus. Bull. 291: 1-210.

Roper, C.F.E., and R.E. Young. (1975). Vertical distribution of pelagic cephalopods. Smihson. Contrib. Zool. 209: 1-51.

Roper, C.L. and M. Veccione. (1997). In situ observations test hypotheses of functional morphology in Mastigoteuthis (Cephalopoda, Oegopsida). Vie Milieu. 47: 87-93.

Roper, C.L., Sweeny, M.J., and C.E. Nauen. (1984). Cephalopods of the world: an annotated and illustrated catelogue of species of interest to fisheries. FAO species catalog. Vol. 3 FAO Fish Synop. 125: 227p. 
Rosa, R. and B.A. Seibel. (2008). Synergistic effects of climate-related variables s uggest future physiological impairment in a top oceanic predator. Proc. Nat. Acad. Sci. 52: 20776-20780.

Rosa, R., Trueblood, L., and B.A. Seibel. (2009). Ecophysiology influence on scaling of aerobic and anaerobic metabolism of pelagic gonatid squids. Physiol. Biochem. Zool. 2009: 419-429.

Seibel, B.A. (2007). On the depth and scale of metabolic rate variation: scaling of oxygen consumption rates and enzymatic activity in the class Cephalopoda (Mollusca). J. Exp. Biol. 210: 1-11.

Seibel, B.A. (2011). Critical oxygen levels and metabolic suppression in oceanic oxygen minimum zones. J. Exp. Bio. 214: 326-336.

Seibel, B.A. (2013). The jumbo squid, Dosidicus gigas (Ommastrephidae), living in oxygen minimum zones II: blood-oxygen binding. Deep-sea Res II. in press.

Seibel, B.A. and J.J. Childress. (1996). Deep breathing cephalopods? Nature 384: 421.

Seibel, B.A. and J.C. Drazen. (2007). The rate of metabolism in marine animals: environmental constraints, ecological demands and energetic opportunities. Phil. Trans. R. Soc. B., 326: 2061-2078.

Seibel, B.A., and V. J. Fabry. (2003). Marine biotic response to elevated carbon dioxide. In: Climate Change and Biodiversity: Synergistic Impacts; Hanna, L. and Lovejoy, T. Eds. Advances in Applied Biodiversity Science, vol. 4. Yale University Press, New Haven, CT p. 59-67.

Seibel, B.A. and P.J. Walsh. (2003). Biological impacts of deep-sea carbon dioxide injection inferred from indices of physiological performance. J. Exp. Biol. 206: 641-650.

Seibel, B.A., Thuesen, E.V., Childress, J.J., and L.A. Gorodezky. (1997). Decline in pelagic cephalopod metabolism with habitat depth reflects differences in locomotory efficiency. Biol. Bull. 192: 262-278.

Seibel, B.A., Thuesen, E.V., and J.J. Childress. (1998). Flight of the vampire: ontogenetic gait-transition in Vampyroteuthis infernalis (Cephalopoda: Vampyromorpha). J. Exp. Biol. 201: 2413-2424.

Seibel, B.A., Thuesen, E.V., and J.J. Childress. (2000). Light-limitation on predator-prey interactions: consequences for metabolism and locomotion of deep-sea cephalopods. Biol. Bull. 198: 284-298. 
Seibel, B.A., Goffredi, S.K., Thuesen, E.V., Childress, J.J., and B.H. Robison. (2004). Ammonium content and buoyancy in midwater cephalopods. J. Exp. Mar. Biol. Ecol. 313: 375-387.

Shipp, R., Mollenhauer, S., and S. von Boletzky. (1979). Electron microscopical and histochemical studies of differentiation and function of the cephalopod gill (Sepia officianlis 1.) Zoomorph. 93: 193-207.

Wells, M.J., Hanlon, R.T., Lee, P.G., and F.P. DiMarco. (1988). Respiratory and cardiac performance in Lolliguncula brevis (Cephalopoda, Myopsida): the effects of activity, temperature and hypoxia. J. Exp. Biol. 138: 17-36.

Vecchione, M. (1991). Dissolved oxygen and the distribution of the euryhaline squid Lolliguncula brevis. Bull. Mar. Sci. 49: 668 - 699.

Voight, J.R., Pörtner, H.O., and R.K. O'Dor. (1994). A review of ammoniamediated buoyance in squids (Cephalopoda: Teuthoidea). Mar. Fresh. Behav. Physiol. 25: 193-303.

Young, R.E. (1972). The systematics and areal distribution of pelagic cephalopods from the seas off Southern California. Smithson. Contr. Zool. 97: 1-159. 


\title{
CHAPTER 3
}

\section{Carbonic anhydrase in the respiratory tissue of marine invertebrates from four} phyla: A meta-analysis

\author{
Albert C. Nyack ${ }^{*}$ and Brad A. Seibel \\ Department of Biological Sciences, College of the Environmental and Life Sciences, \\ University of Rhode Island, 120 Flagg Road, Kingston, RI 02881-0816 \\ * Author for correspondence (email: nyackac@my.uri.edu)
}

In preparation for submission to:

Marine Biology 


\section{Summary}

The respiratory tissues of aquatic organisms are important for gas exchange and other key physiological processes, such as osmoregulation, acid-base balance, and waste excretion. The enzyme carbonic anhydrase (CA) is involved, directly or indirectly, in many of these processes and has been found in every organism and tissue type in which it has been sought. Over the past $\sim 20$ years there has been a growing body of research investigating the role of CA in invertebrate respiratory tissues. In this study we surveyed the literature and quantitatively analyzed the specific activity of $\mathrm{CA}\left(\mu \mathrm{mol} \mathrm{CO}_{2} \cdot \mathrm{mg} \operatorname{prot}^{-1} \cdot \mathrm{min}^{-1}\right)$ in the respiratory tissues of 67 invertebrate species in 4 phyla reported from 30 published studies. We compared the specific CA activity across these species as a function of phylogeny, habitat type, and metabolic rate. Our goal was to ascertain the factors that drive differences in CA activity between species. We found that specific CA activity was significantly greater within the phylum Arthropoda than in the other three phyla investigated. Taxonomic groups within the arthropods also exhibited greater specific CA activity compared to the activity in other animals at the same level. The observed differences between taxonomic groups seem to correlate to differences in the physiological demands of an animal's habitat. For example, the terrestrial arthropods exhibited significantly greater specific CA activity than euryhaline and marine arthropods. A significant correlation between weighted mean specific CA activity and weighted mean metabolic rates was not found among families within Cephalopoda, Bivalvia, or Malacostraca. However, a significant inverse correlation between specific CA activity and metabolic rate was found among genera within bivalves. Interestingly, the scaling analysis at this level showed that 
genera within two families of hydrothermal vent bivalves (Vesicomyidae and Mytilidae) using different metabolic fuel sources exhibited very different specific CA activities despite often being found in the same environments. Our results suggest that, when the effects of whole animal mass and metabolism are accounted for, an organism's habitat drives CA activity.

Key words: carbonic anhydrase, carbon dioxide, invertebrates, respiratory tissue, data synthesis, meta-analysis 


\section{Introduction}

Since the discovery of carbonic anhydrase (CA) (Meldrum and Roughton, 1933a,b; Stadie and O'Brien, 1933) this enzyme has been identified in a myriad of organisms including bacteria (So et al., 2004), marine algae (Moazami-Goudarzi and Colman, 2012; Hofmann et al., 2013), plants (Lamb, 1977; Badger and Price, 1994), invertebrates (Brinkman, 1933; Freeman and Wilbur, 1948; Nielsen and Frieden, 1972; Maren, 1967; reviewed in Henry, 1996, 2001; Bertucci et al., 2013) and aquatic vertebrates (Wright et al., 1989; reviewed in Gilmour and Perry, 2009; Gilmour, 2012). CA rapidly catalyzes the hydration/dehydration of $\mathrm{CO}_{2}$ and water to form

protons $\left(\mathrm{H}^{+}\right)$and bicarbonate $\left(\mathrm{HCO}_{3}{ }^{-}\right)$, and is central to the transport and excretion of $\mathrm{CO}_{2}$ in metazoans. This enzyme also maintains instantaneous equilibrium between gaseous $\mathrm{CO}_{2}$ and ion products, which are important in several essential metabolic processes such as osmoregulation and acid-base balance, particularly in aquatic organisms (Perry et al., 1981; Henry and Cameron, 1982a, b, 1983; Perry, 1986; Henry and Watts, 2001; Grosell et al., 2007). Changes in some environmental conditions, such as salinity, affect the activity and expression of CA activity in intestines of marine-acclimated teleosts (Grosell et al., 2007, 2009) and gills of both teleosts and invertebrates (Henry and Cameron, 1982 a,b; Henry and Saintsing, 1983; Lopez Mañanes et al., 2000). In light of recent concerns about ocean acidification, the relationship between ambient $\mathrm{CO}_{2}$ concentrations and $\mathrm{CA}$ activity in aquatic organisms is beginning to be elucidated, but with mixed results. The expression of cytoplasmic CA in the gills of the rainbow trout (Oncorhyncus mykiss) showed a 20fold increase in mRNA expression (although no increase in enzyme activity) after a 24 
hours hypercapnic challenge (Georgalis et al., 2006). This result contrasts with that of Fehsenfeld and Weihrauch (2013), who found no increase in cytoplasmic CA mRNA expression in the euryhaline crab, Carcinus maenas, after 7 days of hypercapnia. In addition to responding to environmental conditions, the CA activity has also been shown to be strongly correlated to mass-specific metabolic rates in both gill and muscle of cephalopods (Nyack PhD dissertation, Ch2).

In recent decades there has been increased focus on characterizing CA's role in the respiratory tissues of aquatic invertebrates from a broad array of environments (Kochevar and Childress, 1996; Goffredi et al., 1997, 1999; Henry et al., 2012; Nyack et al., in prep). For our purposes here, we define respiratory tissues as epithelial surfaces where the exchange of respiratory gases (i.e. $\mathrm{O}_{2}$ uptake and $\mathrm{CO}_{2}$ excretion) occurs. This definition enabled us to include tissues like the dermal layers of Cnidarians and plume tissue of deep-sea tube worms (e.g. Riftia pachyptila), in addition to the gills of molluses and arthropods. However, it is well established that the function of these "respiratory tissues" in invertebrates extends beyond gas exchange to include ion exchange in crustaceans (Burnett et al., 1981; Henry and Cameron, 1982a,b, 1983; Henry and Saintsing, 1983; Lopez Mañanes et al., 2000), ammonia excretion in cephalopods (Boucher-Rodoni and Mangold, 1994), and $\mathrm{CO}_{2}$ uptake in endosymbiotic clams (Yellowlees et al., 1993), corals (Weis et al., 1989), and in the gills of deep-sea bivalves (Kochevar and Childress, 1996; reviewed in Childress and Girguis, 2011). CA is involved in all of these functions and has been the focus of specific reviews (e.g. Bertucci et al., 2013; Henry, 2001; Henry et al., 2012). 
Teasing apart confounding factors (i.e. phylogeny, environmental conditions, or physiological processes) to identify the predominant drivers underlying variation in CA activity, if one exists, is a challenge that should employ a systematic quantitative analysis across taxa. Meta-analysis is a quantitative synthesis tool that summarizes the results of other studies to ascertain more robust conclusions (Glass, 1976). This approach was first used over a century ago by Pearson (1904) (in Shadish and Haddock, 1994), but did not gain wide-spread use until the 1970s (Glass, 1976). Since then, meta-analyses have been widely used in education (Hedges et al., 1994), medical fields (e.g. Engels et al., 1998), ecological studies (Hedges et al., 1999; Osenberg et al., 1999; Nakagawa and Cuthill, 2007; Preisser and Orrbock, 2012) and climate change (Martens, 1998). However, this technique largely remains scarce in the physiological literature (Havird, et al., 2012).

The ubiquity of CA among organisms has yielded a growing number of studies that quantify both the function of this enzyme and the factors that affect its activity in invertebrate respiratory tissue. To compare these data across species we analyzed the protein-specific activity of $\mathrm{CA}\left(\mu \mathrm{mol} \mathrm{CO}{ }_{2} \cdot \mathrm{mg} \mathrm{prot}^{-1} \cdot \min ^{-1}\right)$ in the respiratory tissues of invertebrates from four phyla (Arthropoda, Cnidaria, Mollusca, and Annelida) using data gathered from 30 peer-reviewed papers. We examined the natural variation in specific CA activity to ascertain if the differences across species are correlated with to taxonomy, differences in tissue type, animal habitat, metabolic rate, or a combination of these factors. 


\section{Methods:}

\subsection{Data collection:}

Carbonic anhydrase data was included in the present analysis if it met the following criteria: 1) CA activity was measured in respiratory tissues (as defined in the introduction) of metazoan invertebrates, 2) the specific activity of CA was expressed in standard international units $\left(\mu \mathrm{mol} \mathrm{CO} 2 \cdot \mathrm{mg}\right.$ protein $\left.{ }^{-1} \cdot \mathrm{min}^{-1}\right)$, or was able to be converted into those units (Weis et al., 1989; Kochevar and Childress, 1996) (i.e. $\mathrm{U} / \mathrm{mg}$ prot were excluded), 3) measurement of specific CA activity was done using electrometric methods ( $\Delta \mathrm{pH}$ or $\mathrm{pH}$-stat), 4) tissues were excised soon after animal capture or field-collected specimens were acclimated for sufficient time after transport to the lab, and 5) for laboratory-kept specimens, the specific CA activity was reported for control animals, i.e. in conditions mimicking that of their natural environment. The control values were obtained from studies meeting the inclusion criteria and standardized to a common temperature (below). Many other studies on specific CA activity in invertebrate respiratory tissues were initially considered, but later excluded because they 1) measured activity using colorimetric methods (Böttcher et al., 1990a,b; Furla et al., 2000; Pavičić-Hamer et al., 2003)--which can underestimate CA activity due to lack of sensitivity or enzymatic inhibition (Henry, 1991a), and 2)

expressed activity in $\mathrm{U} \cdot \mathrm{mg} \operatorname{prot}^{-1}$ (e.g. Burnett et al., 1981; Yellowlees et al., 1993) or $\mathrm{U} \cdot \mathrm{ml}^{-1}$ (LeRoy et al., 2012), or 3) discussed CA activity in terms of other physiological processes (e.g. Weihrauch et al., 1998; Tresguerres et al., 2008). Only two sources provided metabolic rate data for the same animals in which CA activity was also measured (Henry, et al., 1990a; Nyack, PhD dissertation Ch2). 
Because so few studies included in the CA dataset also investigated metabolic rate, or reported masses of study specimens, values for these parameters were obtained through a separate literature search. Suitable data was obtained from search results if it met the following criteria: 1) metabolic rate were measured in whole organisms, 2) metabolic rate was reported as amount of $\mathrm{O}_{2}$ (i.e. not other substrates as in some vent organisms) per unit wet mass per unit time; these parameters could differ between studies as long as they could be standardized (see below); 3) the respirometry temperature was specified, 4) the described animals handling methods suggested minimal animal stress, and 5) metabolic rate was from animals under control conditions.

\subsection{Data acquisition and handling}

Where necessary, CA activity and metabolic rate data were gleaned from figures within publications using GIMP-2 free-access software (http://www.gimp.org). The distances (in pixels) between several printed axis values and the plot's origin ( $\mathrm{x}-\mathrm{y}$ intercept) were measured. The mean axis value:pixel ratio was calculated and that ratio was used to convert number of pixels measured for plotted data and error bars into values on the parameter of interest.

The genera and species used here were those reported in the original publications. For the purposes of the analysis of higher nodes and taxonomic comparisons, the higher level nomenclature used was that conveyed by any two of three databases: Integrated Taxonomic Information Service (http://www.itis.gov), the Encylopedia of Life project (http://www.eol.org), and the World Registry of Marine 
Species (http://www.marinespecies.org). It should be noted that through this process it was revealed that several species listed in this study have since been reclassified into new genera: Protothaca staminea was reclassified as Leukoma stamina (Huber, 2010; Coan and Valentich-Scott, 2012), Xenia macrospiculata was recategorized as Ovabunda macrospiculata (van Ofwegen et al., 2013), and Chasmagnathus ganulata has been renamed as Neohelice granulata (Sakai et al., 2006). The bivalve reported by Kochevar and Childress (1996) as 'Seep Mytilid 1a' has since been identified as Bathymodiolus childressi (Gufstason et al., 1998).

\subsection{Standardization of data from the literature}

The majority of the specific CA activity was reported in units of $\mu \mathrm{mol} \mathrm{CO}_{2}$. $\mathrm{mg} \operatorname{protein}^{-1} \cdot \min ^{-1}$, or was easily converted into these units. Some papers reported CA activities as units of $\Delta \mathrm{pH} \cdot \mathrm{mg}$ protein $^{-1} \cdot \min ^{-1}$ (Kochevar and Childress, 1996; Weis et al., 1989; Weis, 1991, 1993; Weis and Reynolds, 1999). Because the data in these four publications were obtained using the same assay buffers $(25 \mathrm{mM}$ veronal buffer), volumes $(3 \mathrm{ml})$, and low assay temperatures $\left(2-5^{\circ} \mathrm{C}\right)$ the conversion ratio of $0.351 \Delta \mathrm{pH} \cdot \mathrm{mg}$ protein ${ }^{-1} \cdot \min ^{-1} \approx 1 \mu \mathrm{mol} \mathrm{CO} 2 \cdot \mathrm{mg} \operatorname{protein}^{-1} \cdot \min ^{-1}$ (Kochevar and Childress, 1996) was applied. The majority of studies in the dataset measured specific CA activity between $0-5{ }^{\circ} \mathrm{C}$, however the values were converted to $15{ }^{\circ} \mathrm{C}$ using a $\mathrm{Q}_{10}$ of 2 (Meldrum and Roughton, 1933a) because this was the mean temperature of the metabolic rate studies included in our dataset.

All metabolic rates were converted into the same units $\left(\mu \mathrm{mol} \mathrm{O} \mathrm{O}_{2} \cdot \mathrm{g} \mathrm{wwt}^{-1}\right.$.

$\min ^{-1}$ ) for comparison between species. Dry mass-specific metabolic rates were only reported for studies among bivalves, and were converted to wet mass using $\%$ water 
values for a species where possible [e.g. Corbicula fluminea (Byrne et al., 1990); Ligumia subrostrata (Dietz, 1974)], or an assumed water content of 80\% (Potts, 1958; Graney and Giesy, 1988). The metabolic rate was also standardized to a temperature of $15{ }^{\circ} \mathrm{C}$ assuming a $\mathrm{Q}_{10}=2$, unless otherwise stated in the literature for a particular species, or calculable from thermal treatments within the publication.

The metabolic rates $(Y)$ for each species were then normalized to $10 \mathrm{~g}$ animal mass using the scaling formula $Y=a M^{b}$, where $a$ is a taxon-specific normalization constant specific, $b$ is the scaling coefficient (slope), and $M$ is animal mass. Normalization constants were calculated from metabolic rates standardized to $15{ }^{\circ} \mathrm{C}$ divided by the mean mass reported in each paper. Scaling exponents were either derived from the literature, or $b=-0.25$ was assumed and applied within a family. The metabolic rate at $15{ }^{\circ} \mathrm{C}$ was then normalized to $10 \mathrm{~g}$ for each species.

\subsection{Weighted mean values}

Comparisons of specific CA activity in terms of tissue type, taxonomic group, animal habitat category, or assay conditions utilized all species in the full dataset sampled from publications as described above. However, species within a genus or family were often represented by a single value (from one study). Therefore a weighted mean value was calculated for specific CA activity and, when available for a given species, metabolic rate. This approach was employed to 1) account for the variability in sample size and mean values between studies and 2) derive representative $\mathrm{CA}$ activities and metabolic rates for comparison.. The weighted mean specific CA activity and metabolic rate were calculated according to: 


$$
\bar{m}=\sum_{i=1}^{n} m_{i}\left[\frac{x_{i}}{\sum_{i=1}^{n} x_{i}}\right]
$$

In this equation $m_{i}$ is the variable of interest (CA activity or metabolic rate) from a given study, $x_{i}$ is the number of individuals of that species used in the experiment, and $n$ is the number of studies reporting data at a predetermined taxonomic level. In accordance with the results from the analysis of higher nodes the weighted mean specific CA activity and metabolic rate was calculated at the family level.

\subsection{Analysis of higher nodes}

We utilized an analysis of higher nodes described by Harvey and Pagel (1991) to determine the taxonomic level to calculate a weighted mean specific CA activity and metabolic rate. This method uses a nested ANOVA to partition the total variation among species $\left(\delta_{\text {tot }}^{2}\right)$ into groups representing the variation in successively higher levels of taxonomy from species (s) through class (c).

$$
\delta_{\text {tot }}^{2}=\delta_{\mathrm{s}(\mathrm{g})}^{2}+\delta_{\mathrm{g}(\mathrm{f})}^{2}+\delta_{\mathrm{f}(\mathrm{o})}^{2}+\delta_{\mathrm{o}(\mathrm{c})}^{2}
$$

The term on the left is the total variance among species on the trait of interest, in this case specific $\mathrm{CA}$ activity $\left(\mu \mathrm{mol} \mathrm{CO}_{2} \cdot \mathrm{mg} \operatorname{prot}^{-1} \cdot \mathrm{min}^{-1}\right)$. This total variation is partitioned among species within a genus, genera within a family, etc. If the cumulative portion of variance among species is found by summing the variance from the highest level to the lowest, then when $\delta^{2}{ }_{\mathrm{s}(\mathrm{g})}$ is added, $100 \%$ of the variance will be accounted for (Harvey and Pagel, 1991). The percent variance of each component was then determined by dividing both sides of the equation by $\delta_{\text {tot }}^{2}$ and multiplied by 100 . 


\subsection{Statistical analysis}

Analysis of variance (ANOVA; $\alpha=0.05$ ) was used to test for differences in CA activity among taxa. When differences were detected, a Student's t-test was used to identify differences between categories. The relationship between weighted mean CA activity and metabolic rate was examined using regression analysis. Slopes of regressions were considered significantly different from zero at the $95 \%$ confidence level $(\mathrm{P}<0.05)$. Analyses were done using JMP software version 10 (SAS Institute, Carey, NC).

\section{Results}

\subsection{Summary of literature search}

The literature search yielded 30 publications that met our inclusion criteria for specific CA activity. Most of these were from the Journal of Experimental Zoology (30\%) and Comparative Biochemistry and Physiology (20\%), and $80 \%$ of the publications used in the dataset were from 1990 or more recent. Surprisingly, few studies in the CA activity dataset stated mass range (Henry et al., 1990b; Henry and Campoverde, 2006) or mean mass (Wheatly and Henry, 1987) of their study organisms.

The metabolic rate and mass data was acquired from 76 publications, most of which were from the Journal of Experimental Biology and Marine Biology. All publications were from articles more recent than 1970 , with $22 \%$ of the data from publications in each of the 1980s and 2000s. 


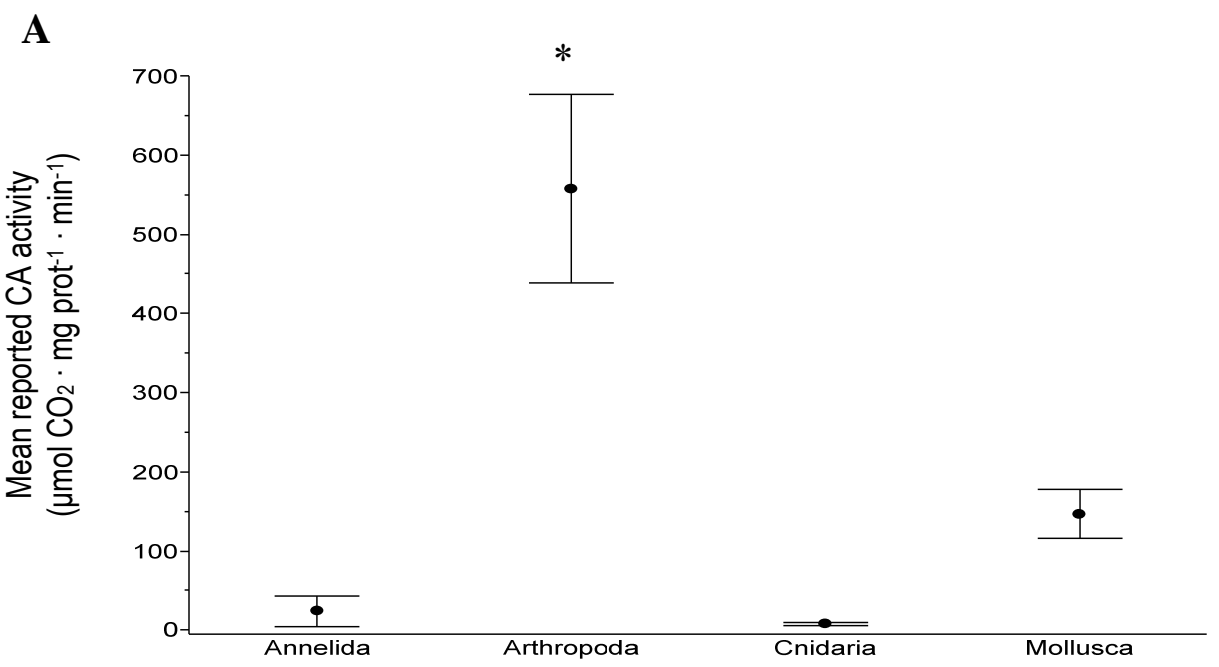

B

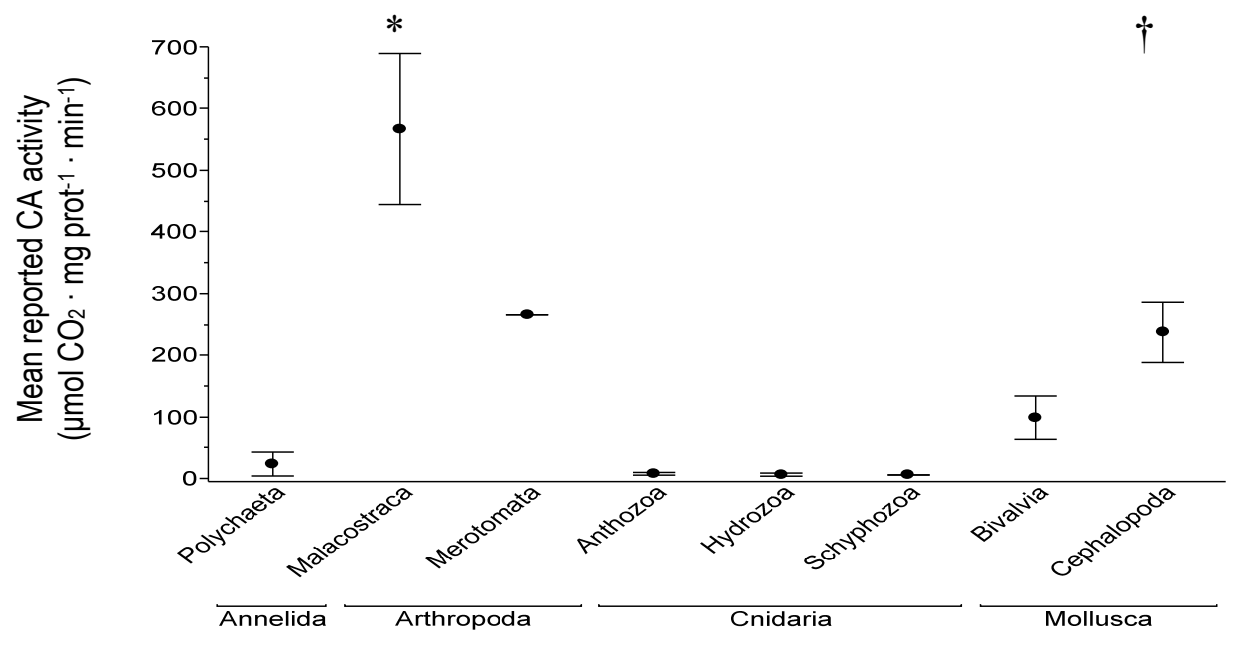

C

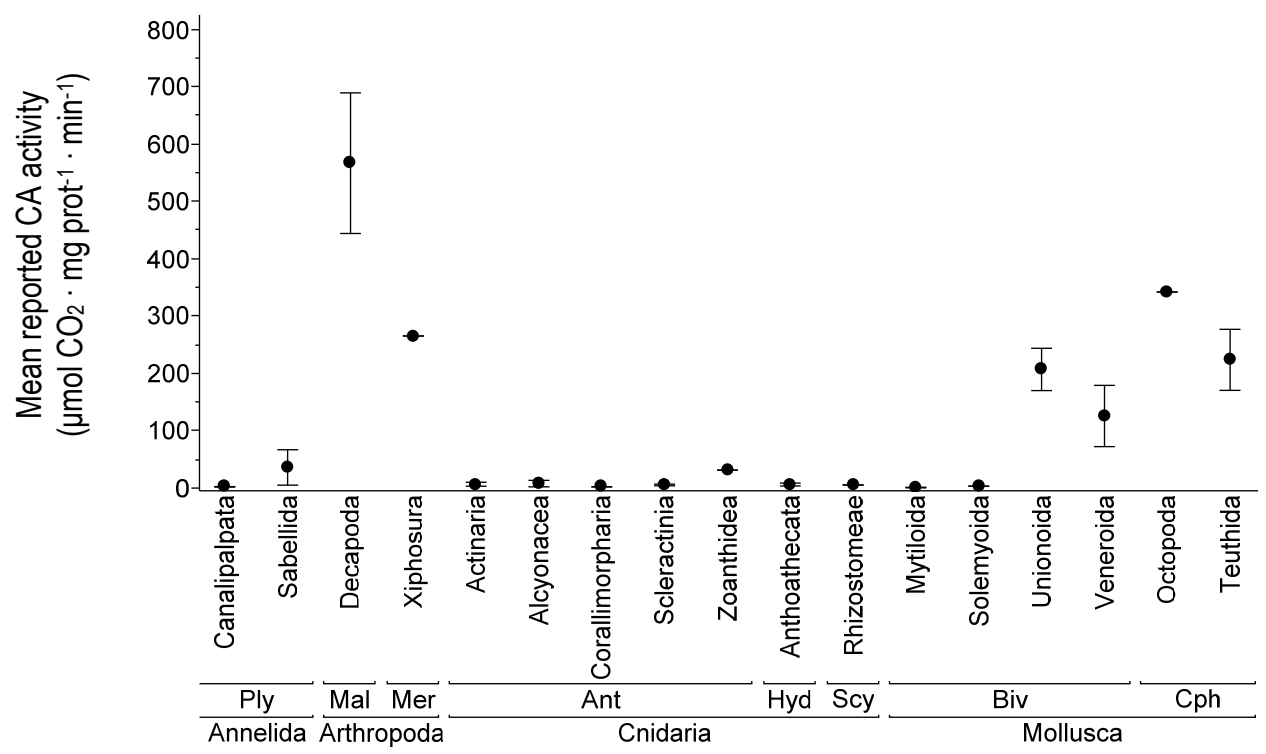


Figure 1 (previous page). The mean of reported CA specific activity in respiratory tissues reported in the literature normalized to $15{ }^{\circ} \mathrm{C}$ grouped at different taxonomic levels. A) Activity in phylum Arthropoda was significantly greater than the other phyla (ANOVA, $\mathrm{P}<0.0001$ ). B) The specific CA activity among class Malacostraca was significantly greater than that in Polychaeta, Anthozoa, Bivalvia, or Cephalopoda $(\mathrm{P}<0.0001)$. Merostomata, Scyphozoa, and Hydrozoa were excluded from the analysis due to small sample size. Only phyla Mollusca had sufficient data to compare classes within a phyla; the specific CA activity was significantly greater among cephalopods ( $\mathrm{t}$-test, $\mathrm{P}=0.0303$ ) than bivalves as noted by $\uparrow$. C) Inter-ordinal analysis revealed that specific $\mathrm{CA}$ activity among decapods was significantly greater (ANOVA, $\mathrm{P}=0.0053$ ) than all other orders except Teuthida ( $\mathrm{t}$-test, $\mathrm{P}=0.0645$ ). The activity in Teuthid squids, however, was not statistically different from other orders. Seven additional species within Canalipalata, Solemyoida, Corallimorpha, Octopoda, Unionoida, and Zoanthidea were excluded from this analysis. Class abbreviations in (C) are as follows: Polychateata (Ply), Malacostraca (Mal), Merostomata (Mer), Anthozoa (ant), Hydrozoa (Hyd), Scyphozoa (Scy), Bivalvia (Biv), and Cephalopoda (Cph). Values are means \pm SEM. Number of mean values sampled and numbers of species are presented in Table 1.

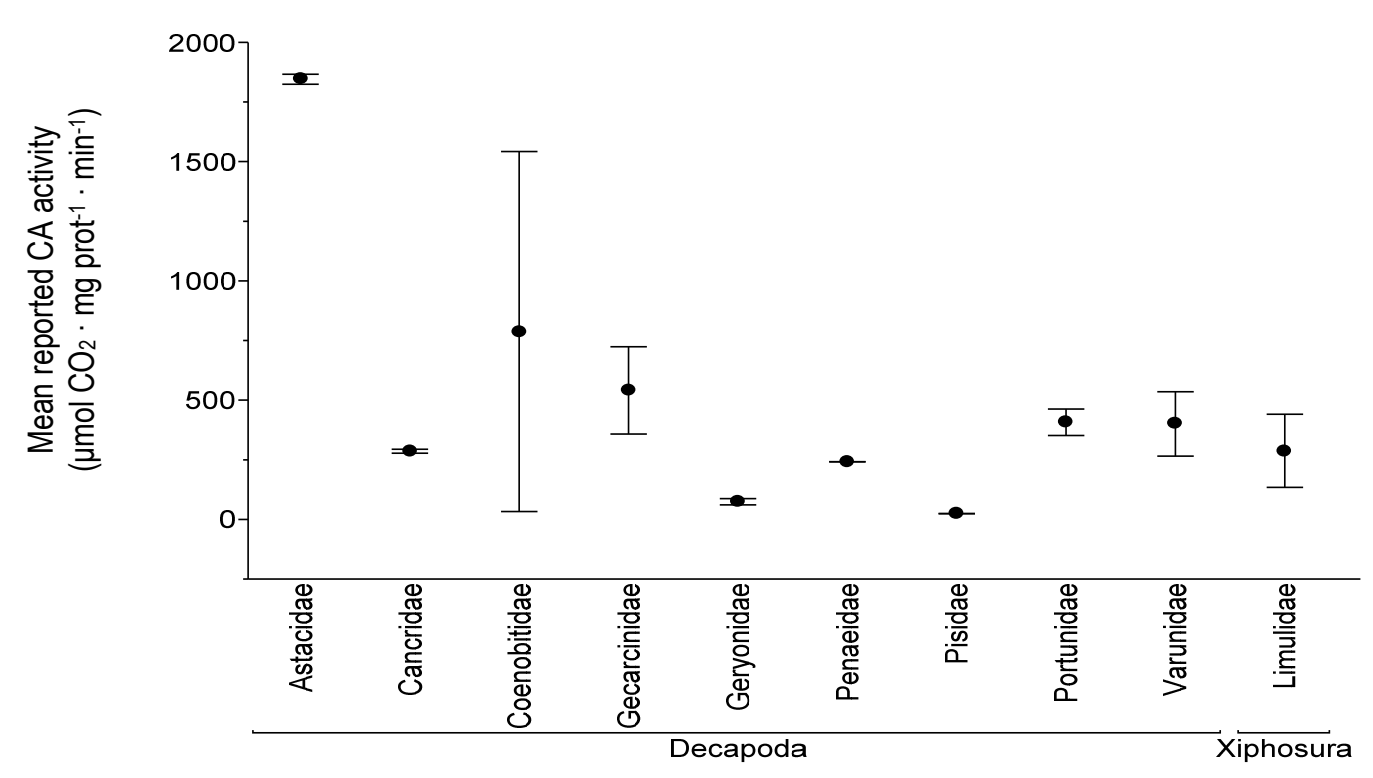

Figure 2. Mean CA specific activity among families of decapod crustaceans. Portunidae is represented by three species and Gecarcinidae, Geryonidae, and Varunidae are represented by 2 species. The remaining families are represented by a single species. Values are means of reported values in the literature \pm SEM normalized to $15^{\circ} \mathrm{C}$. 


\subsection{Specific CA activity between taxa}

The published specific activity of CA in respiratory tissues among the 67 species in the data set was recalculated to the same units and standardized to $15^{\circ} \mathrm{C}$ in order for comparison among phyla (Fig. 1A; Table 1). The mean specific CA activity in the gills of all arthropods $\left(558.2 \mu \mathrm{mol} \mathrm{CO}_{2} \cdot \mathrm{mg} \mathrm{prot}^{-1} \cdot \mathrm{min}^{-1}\right)$ was nearly four times that of molluscs, the phylum with the next highest activity, and 66 times the activity exhibited among cnidarians $\left(8.43 \mu \mathrm{mol} \mathrm{CO} 2 \cdot \mathrm{mg} \mathrm{prot}^{-1} \cdot \mathrm{min}^{-1}\right)$. Activity between classes and orders within the four phyla was also investigated (Fig. $1 \mathrm{~B}$ and C), however there were fewer groups that had sufficient numbers of published means for comparisons with each lower level examined. At the class level, the highest specific CA activity was found in the class Malacostraca (Arthropoda) (Fig. 1B). Only phylum Mollusca had sufficient reports of mean activity for an analysis between classes. Cephalopods had significantly greater specific $\mathrm{CA}$ activity than bivalves (t-test, $\mathrm{P}=0.0303$ ). Nine of the 17 orders were excluded from an inter-order analysis of specific CA activity because they were represented by 1-2 published mean values. Of the remaining eight orders, the specific CA activity in Decapods was significantly greater than all other orders, except squids (Teuthida) (Fig. 1C). Interestingly, the gill tissue of Teuthid squids, with some species exhibiting very high metabolic rate, exhibited similar activities (about $200 \mu \mathrm{mol} \mathrm{CO} 2 \cdot \mathrm{mg} \operatorname{prot}^{-1} \cdot \mathrm{min}^{-1}$ ) to gill tissues of the freshwater bivalves (Unionoida) (Fig 1C; Table 1). A statistical analysis among families within a phylum was not possible because of low sample size at this level or below. This is illustrated in Fig. 2 that show the mean specific CA activity of families within

Arthropoda, the most represented 
Table 1. Specific CA activity ( $\mu \mathrm{mol} \mathrm{CO} 2 \mathrm{mg}$ prot min) from published values averaged at each taxonomic level. Values are the mean of the reported activities from the studies sampled \pm SEM (number of mean values reported for a given grouping, number of species)

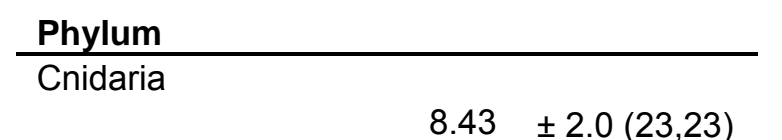

$8.43 \pm 2.0(23,23)$

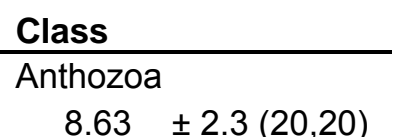

$\infty$

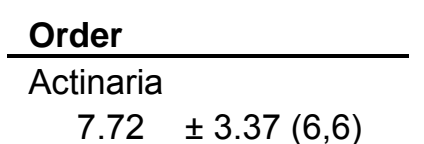

$$
8.82 \pm 5.50(6,6)
$$

Alyconacea

Corallimorpharia

$3.30 \quad(1,1)$

Scleractinia $6.32 \pm 1.46(6,6)$

Zoanthidea

32.23

Anthoathecata

$7.24 \pm 2.58(2,2)$

$7.24 \pm 2.58(2,2)$

Schyphozoa

$6.63(1,1)$

Rhizostomeae $6.63(1,1)$

\section{Family}

Actiniidae

Aiptasiidae

Stoichactidae

$0.91 \pm 0.35(3,3)$

$11.41 \pm 1.38(3,2)$

$20.76 \pm 0.00(1,1)$

Alcyoniidae

Gorgoniidae

$2.11 \pm 0.00(1,1)$

$35.59 \pm 0.00(1,1)$

Plexauridae

$6.63 \pm 2.42(2,2)$

Xeniidae

$0.98 \pm 0.21(2,2)$

Discosomatidae

$3.3(1,1)$

Agariciidae

Caryophylliidae

Faviidae

$2.74 \quad(1,1)$

Oculinidae

Pocilloporidae

$11.22(1,1)$

Siderastreidae

$8.59 \quad(1,1)$

Sphenopidae

$32.23(1,1)$

Milleporidae

$7.24 \pm 2.58(2,2)$

Cassiopeidae

$6.63(1,1)$ 
Table 1 (continued).

Phylum

$24.34 \pm 19.39(8,5)$

Arthropoda

$558.20 \pm 119.01(32,14)$

$\stackrel{\infty}{0}$
Class

Polychaeta

$24.34 \pm 19.39(8,5)$

$567.61 \pm 122.52(31,13)$

Decapoda

$567.61 \pm 122.52(31,13)$

Xiphosura

$266.42(1,1)$

$266.42 \quad(1,1)$

\section{Canalipa}

Sabellida

$36.96 \pm 30.77(5,4)$

Merostomata

(1,1)
Family

Chaetopteridae

$3.31 \pm 0.44(3,1)$

Siboglinidae

$36.96 \pm 30.77(5,4)$

Astacidae

Cancridae

Coenobitidae

Gecarcinidae

Geryonidae

Penaeidae

Pisidae

Portunidae

Varunidae

Limulidae 
Table 1 (continued).

\begin{tabular}{l} 
Phylum \\
\hline Mollusca \\
$147.51 \pm 30.92(26,23)$
\end{tabular}$$
\text { ivalvia }
$$$$
99.67 \pm 35.22(17,14)
$$

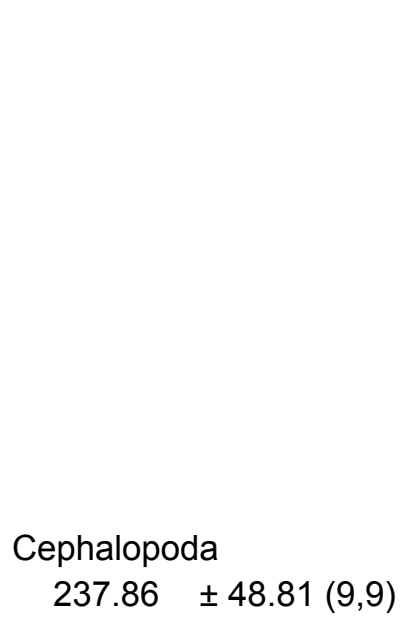

Order
Mytiloida

$1.80 \pm 0.5(4,3)$

Solemyoida

$4.444 \quad(1,1)$

Unionida

$208.03 \pm 36.98(2,1)$

Veneroida

$126.67 \pm 53.39(10,9)$

Family

Mytilidae

Solemyidae

Unionidae

Corbiculidae

Lucinidae

Mactridae

Veneridae

Vesicomyidae

Teuthida

$224.73 \pm 53.31(8,8)$

Octopoda

342.96

$(1,1)$
Chiroteuthidae

Cranchiidae

Gonatidae

Histioteuthidae

Loliginidae

Mastigoteuthidae

Ommastrephidae

Bolitaenidae
$1.80 \pm 0.5(4,3)$

$4.44 \quad(1,1)$

$208.03 \pm 36.98(2,1)$

$580.9 \quad(1,1)$

$13.45 \quad(1,1)$

$108.89 \pm 18.65(2,1)$

$3.25 \quad(1,1)$

$90.27 \pm 26.68(5,5)$

$294.86 \quad(1,1)$

$162.34 \quad(1,1)$

$46.6 \quad(1,1)$

$136.03 \quad(1,1)$

$298.43 \pm 78.52(2,1)$

$482.16 \quad(1,1)$

$78.97 \quad(1,1)$

$342.96 \quad(1,1)$ 
group in the dataset in terms of number of studies. The freshwater crayfish, Pacifastacus leniusculus (Astacidae), and the land crabs Birgus latro (Coenobitidae), Cardisoma guanhumi and Gecarcinus lateralis (Gecarcinidae) all exhibited specific CA activities between $1000-2000 \mu \mathrm{mol} \mathrm{CO} 2 \cdot \mathrm{mg} \mathrm{prot}^{-1} \cdot \mathrm{min}^{-1}$, activities that were 560 times higher than mean activity in gill tissue from other families (Table 1).

\subsection{Specific CA activity by respiratory tissue type}

The specific activity of CA was compared as a function of respiratory tissue type between the phyla (Fig. 3). The CA activity per mg protein was significantly greater in the gill tissues of arthropods $\left(558.2 \mu \mathrm{mol} \mathrm{CO} 2 \cdot \mathrm{mg} \mathrm{prot}^{-1} \cdot \mathrm{min}^{-1}\right)$ than in the gills of molluscs $\left(147.51 \mu \mathrm{mol} \mathrm{CO} 2 \cdot \mathrm{mg} \operatorname{prot}^{-1} \cdot \min ^{-1}\right)$. The specific CA activities between respiratory tissues within a phylum were not statistically different. In other words, the notopodia of Chaetopterus variopedatus (Polychaeta: Canalipalpata), a coastal annelid collected off Santa Barbara, CA (Kochevar and Childress, 1996), and the plume of deep-sea tube worms were not different (Table 1; t-test, $\mathrm{P}=0.44$ ) despite coming from different environments. Similarly, the specific CA activity among Cnidarians was very similar between polyp segment $\left(8.75 \mu \mathrm{mol} \mathrm{CO} 2 \cdot \mathrm{mg} \mathrm{prot}^{-1} \cdot \min ^{-}\right.$

${ }^{1}$ ) and whole animal $\left(8.72 \mu \mathrm{mol} \mathrm{CO} 2 \cdot \mathrm{mg} \mathrm{prot}^{-1} \cdot \mathrm{min}^{-1}\right)$. 


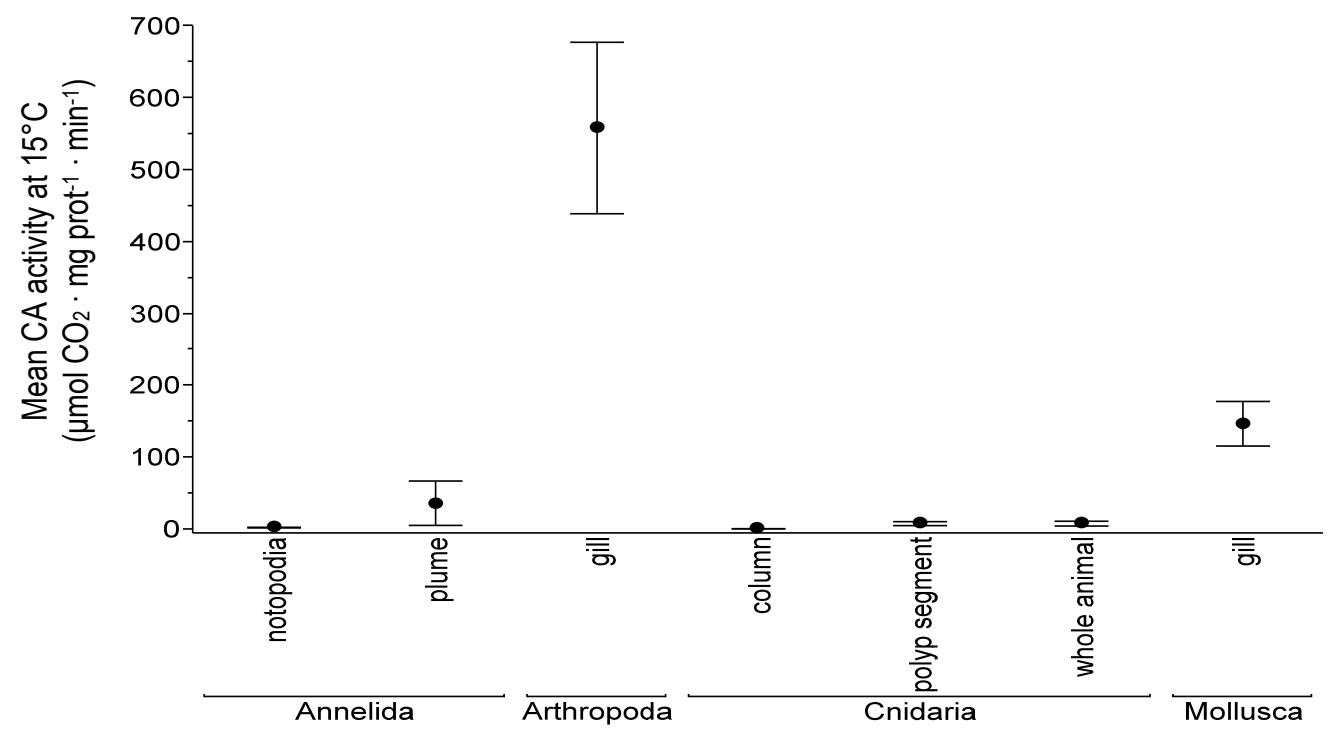

Figure 3. The specific activity of CA between respiratory tissue types grouped by phylum. Activity in arthropod gills was significantly greater than that in respiratory tissue from all other phyla (ANOVA, P < 0.0004). Specific CA activity in molluscan gills was not significantly greater than activity in the remaining species. Values are means of reported values in the literature $\pm \mathrm{SEM}$.

\subsection{Specific CA activity in relation to habitat}

Animals were also grouped into habitat categories based on environmental characterizations in the literature (Fig. 4). All annelids and cnidarians in this study were exclusively marine, as were all cephalopod species except for the brief squid, $L$. brevis, which also inhabits estuarine waters (Hendrix et al., 1981; Bartol et al., 2002). The euryhaline animals within the class Malacostraca were acclimated to marine salinities ( $\geq 29 \mathrm{ppt})$ in the lab, whereas animals labeled as marine are exclusive to that habitat. The specific CA activity values reported for the gill tissue of the terrestrial malacostracan species, Birgus latro and Gecarcinus lateralis, $(\mathrm{n}=4)$ were significantly greater than the activities of the animals exclusive to marine habitats 
(Fig. 4). The data suggest decreasing specific CA activity among arthropods with transition among species from terrestrial to marine habitats. When grouped by habitat, the mean reported specific CA activity among marine cephalopods was significantly greater than other exclusively marine organisms (ANOVA, $\mathrm{P}<0.0001$ ), and twice that of the next closest group (marine malacostracans). The mean specific CA activity in

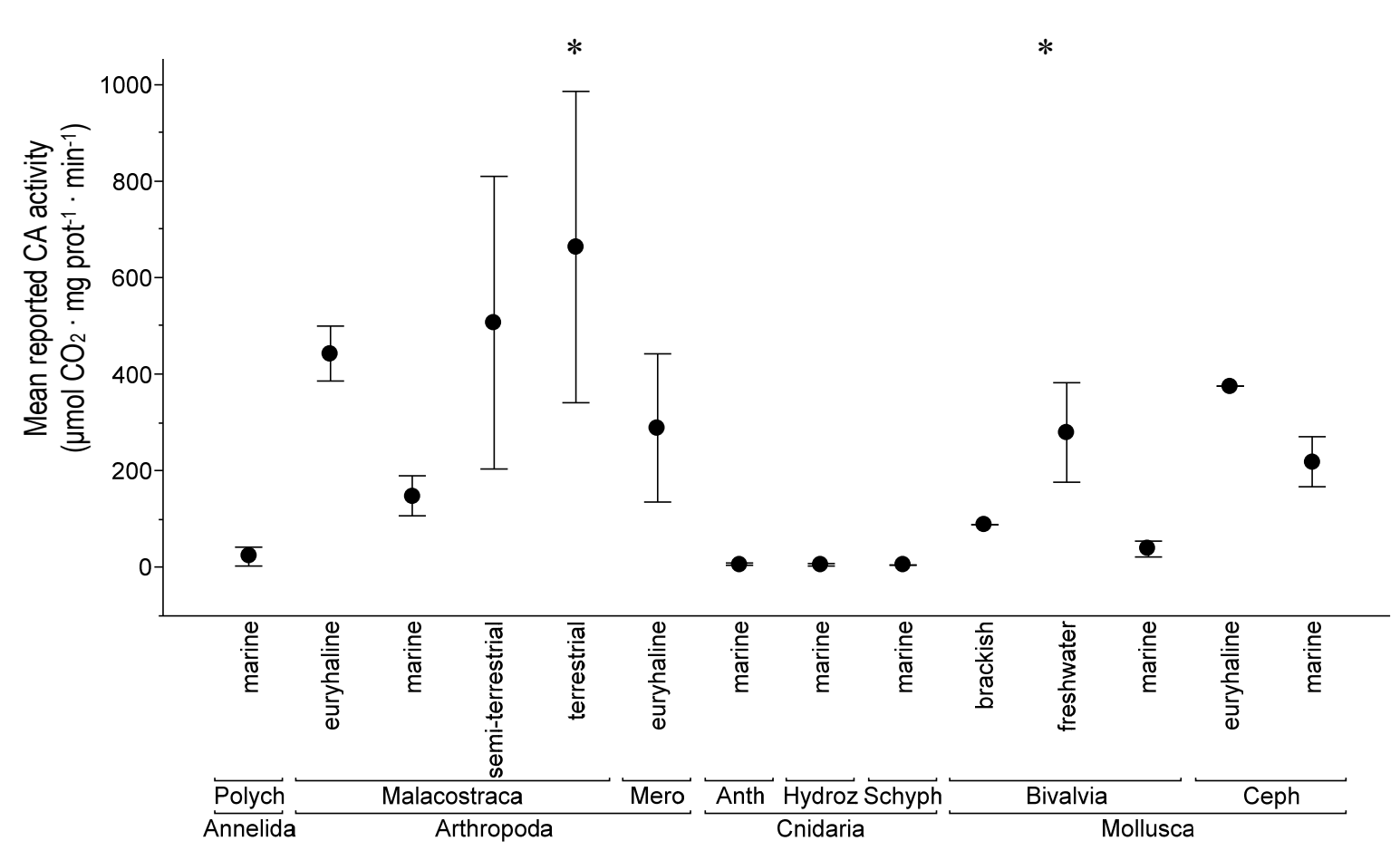

Figure 4. Mean specific CA activity reported in respiratory tissues compared to organism habitat. Organisms are further grouped by class within phylum. The gills of freshwater bivalves showed significantly greater activity than those of marine bivalve species $(\mathrm{P}=0.0017)$. Pair-wise comparisons (Student's t-test) showed that specific $\mathrm{CA}$ activity in the gills of the two terrestrial arthropods species, B. latro and G. lateralis, were significantly greater than that found among the marine species $(\mathrm{P}=0.0278)$. Values shown are means \pm SEM.

the gills of freshwater bivalve species Rangia cuneata, Corbicula fluminea, and Ligumia subrostrata was $281.13 \mu \mathrm{mol} \mathrm{CO} 2 \cdot \mathrm{mg} \operatorname{prot}^{-1} \cdot \min ^{-1}, 7$ times the activity of marine bivalves $\left(39.97 \mu \mathrm{mol} \mathrm{CO} 2 \cdot \mathrm{mg} \mathrm{prot}^{-1} \cdot \mathrm{min}^{-1}\right)$, and also statistically the same as 
that reported in the gills of cephalopods and euryhaline malacostracans (Fig. 4). Because $R$. cuneata is an iono- and osmoconformer at 10 ppt (Henry and Saintsing, 1983) the CA activity reported at this salinity was excluded from the analysis, however values for freshwater acclimated specimens of this species were included.

\subsection{Subcellular fraction and specific CA activity}

The specific activity for CA reported in the studies used was either that derived from crude homogenate (minimal, if any, centrifugation) or of the cytoplasmic fraction, which contains the cytosolic and membrane-bound CA isozymes after centrifugation removes large particulates and mitochondria. A difference in activity between subcellular fractions was also examined. When fractions were compared among all studies regardless of taxonomy, the specific CA activity reported for cytoplasmic fraction $\left(452.95 \pm 64.61 \mu \mathrm{mol} \mathrm{CO} 2 \cdot \mathrm{mg} \operatorname{prot}^{-1} \cdot \mathrm{min}^{-1}, \mathrm{n}=55\right)$ was significantly greater than that for crude homogenate $\left(55.43 \pm 13.92 \mu \mathrm{mol} \mathrm{CO} \mathrm{CO}_{2} \cdot \mathrm{mg}\right.$ $\left.\operatorname{prot}^{-1} \cdot \min ^{-1}, \mathrm{n}=56\right)(\mathrm{P}<0.0001)$. However, this may be due to the fact that all of the studies among arthropods, except for Morris and Greenaway (1990), measured activity in the cytoplasmic fraction. Also, arthropods exhibited statistically greater specific CA activity than the other three phyla. It was not possible to statistically compare activity between the fractions among arthropods because there were only 2 data points for crude homogenate activity. Studies on annelids and cnidarians all examined CA activity in crude homogenate, and activities in these phyla are lower than arthropods. Among molluscs, five of the 26 studies examining CA activity used cytoplasmic fractions, but there was not a significant difference between these fractions when 
compared within molluses $(\mathrm{P}=0.1348)$ (Fig. 5). However, nine of the crude homogenate data points were CA specific activity from cephalopods, which was seven times greater than crude homogenate from bivalves (Table 1). The specific CA activity in the cytoplasmic fraction among bivalves $\left(242.95 \mu \mathrm{mol} \mathrm{CO} \mathrm{C}_{2} \cdot \mathrm{mg} \mathrm{prot}^{-1} \cdot \mathrm{h}^{-1}\right)$ was significantly greater than the crude homogenate activity $(\mathrm{P}=0.0042)$ and very close to the crude homogenate activity found in cephalopods $\left(237.86 \mu \mathrm{mol} \mathrm{CO} 2 \cdot \mathrm{mg} \mathrm{prot}^{-1} \cdot \mathrm{h}^{-}\right.$ 1) (Fig. 5).

\subsection{Analysis of higher nodes}

An analysis of higher nodes (Harvey and Pagel, 1991) was used to identify the appropriate taxonomic level for subsequent comparisons. The majority of the

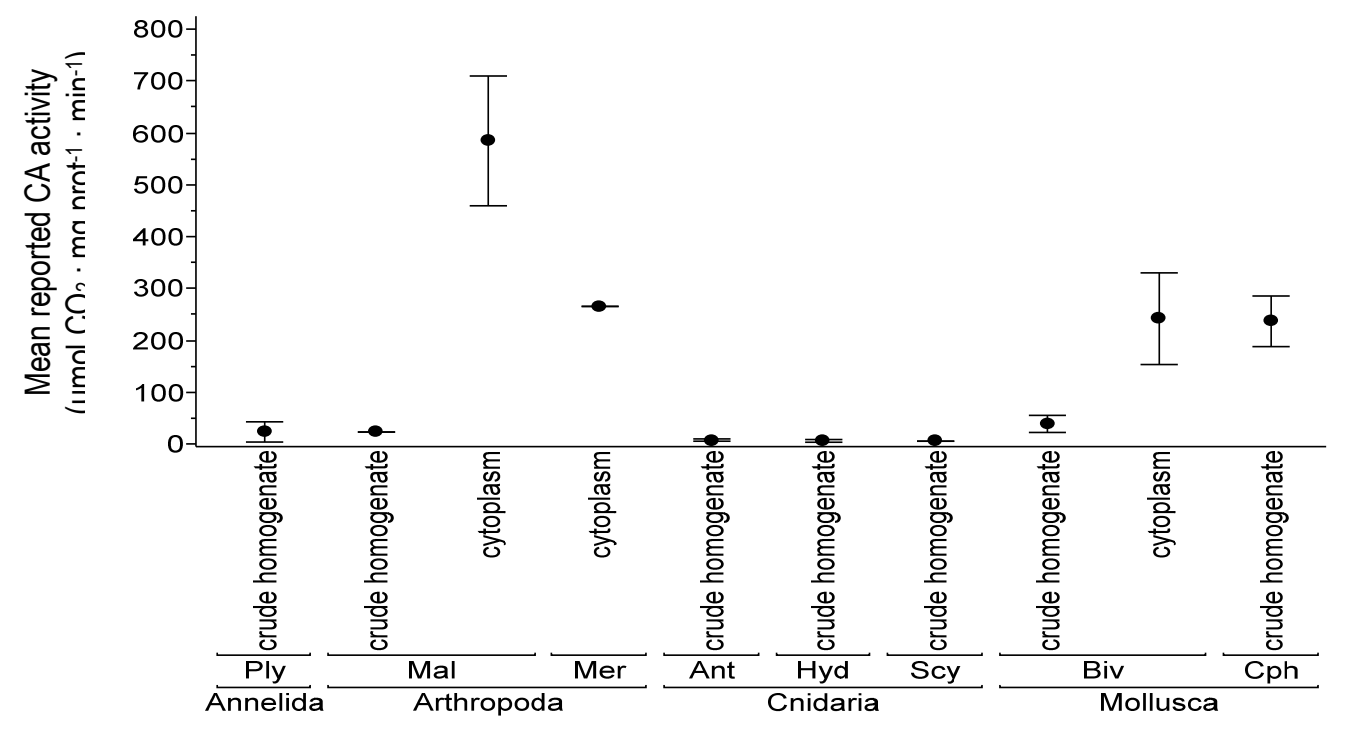

Figure 5. Mean reported specific CA activity from respiratory tissue subcellular fractions grouped by class within their phyla. The cytoplasmic fraction among bivalves was significantly greater than crude homogenate only when compared within the class $(\mathrm{P}=0.0042)$. When activity between these fractions was compared within lower taxonomic levels for which both fractions were measured no significant differences were detected. The crude homogenate in Malacostraca is from 1 reported mean value of B. latro (Morris and Greenaway, 1990) Values shown are means \pm SEM. 
variability in phyla Cnidaria (41\%) was among orders within a class (Table 2). However, Scyphozoa and Hydrozoa each had specific CA activity represented by a single family in each class. All of the annelids reported in the literature were from class Polychaeta. Therefore, the analysis in this group was limited to comparing taxonomic levels no higher than among families within an order. Most of the variability, $76 \%$, was between genera within the two families of annelids, Chaetopteridae and Siboglinidae. The majority of the variation in gill CA activity, $48 \%$ and $62 \%$, was among families within an order for Arthropods and Molluscs, respectively. Similarly, the majority of variance in metabolic rates among cephalopods also is reported to be at the family level (Seibel, 1998; Seibel et al., 2000) as well. These results were used as a guide to determine which taxonomic level weighted mean values were calculated.

Table 2. The taxonomic distribution of specific CA activity variance within each phyla. Values are percentages of total variance accounted for at successive taxonomic levels estimated from nested ANOVA.

\begin{tabular}{|c|c|c|c|c|c|c|c|c|c|}
\hline \multirow[b]{2}{*}{ Cnidaria } & \multirow[t]{2}{*}{$\begin{array}{l}\text { Among: } \\
\text { Within: }\end{array}$} & \multicolumn{2}{|c|}{$\begin{array}{l}\text { species } \\
\text { genera }\end{array}$} & \multicolumn{2}{|c|}{$\begin{array}{r}\text { genera } \\
\text { families }\end{array}$} & \multicolumn{2}{|c|}{$\begin{array}{c}\text { families } \\
\text { orders }\end{array}$} & \multicolumn{2}{|c|}{$\begin{array}{l}\text { orders } \\
\text { classes }\end{array}$} \\
\hline & & 13.39 & (14) & 20.11 & $(12)$ & 25.61 & (8) & 40.88 & (6) \\
\hline Annelida & & 24.40 & (4) & 75.56 & (4) & 0.04 & (2) & ----- & -- \\
\hline Arthropoda & & 7.21 & (14) & 8.83 & (12) & 47.64 & (10) & 36.33 & (2) \\
\hline Mollusca & & 11.08 & (23) & 12.27 & (17) & 62.00 & (15) & 14.65 & (6) \\
\hline
\end{tabular}

The value in parentheses is the total number within the next lower taxonomic group

\subsection{Weighted mean specific CA activity, metabolic rate, and mass}

Among the species for which specific CA activities were reported in the literature, there was sufficient reported metabolic rate data for analysis of phyla Mollusca and Arthropoda. The weighted mean specific CA activity and metabolic rate 
calculated within families are listed in Table 3. Within the molluscs metabolic rate data was obtained from the literature for 13 species from seven genera (6 families) of bivalves, and 9 species ( 8 families) of cephalopods. The estimates of metabolic rates among bivalves ranged from $0.2-6 \mu \mathrm{mol} \mathrm{O}_{2} \cdot \mathrm{g}^{-1} \cdot \mathrm{h}^{-1}$, and cephalopod weighted mean metabolic rates ranged $1-18 \mu \mathrm{mol} \mathrm{O}_{2} \cdot \mathrm{g}^{-1} \cdot \mathrm{h}^{-1}$. Among phyla Arthropoda the weighted mean metabolic rate ranged from $1.15 \mu \mathrm{mol} \mathrm{O} \cdot \mathrm{g}^{-1} \cdot \mathrm{h}^{-1}$ at $10 \mathrm{~g}$ and $15{ }^{\circ} \mathrm{C}$ for the bathyal crab C. fenneri to over $10 \mu \mathrm{mol} \mathrm{O}_{2} \cdot \mathrm{g}^{-1} \cdot \mathrm{h}^{-1}$ for L. polyphemus at the same temperature and mass (Table 3).

Figure 6A depicts a significant correlation between total CA activity ( $\mu$ mol $\mathrm{CO}_{2} \cdot \mathrm{g}^{-1}$ animal $\cdot \mathrm{min}^{-1}$ ) and metabolic rate (redrawn from Nyack $\mathrm{PhD}$ dissertation, chapter 2). However, no relationship exists when CA activity is normalized to protein,

A

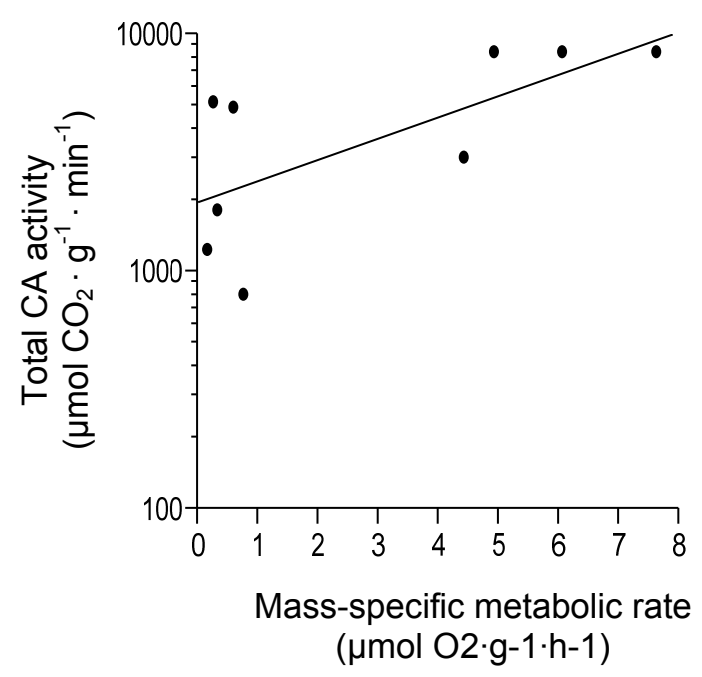

B

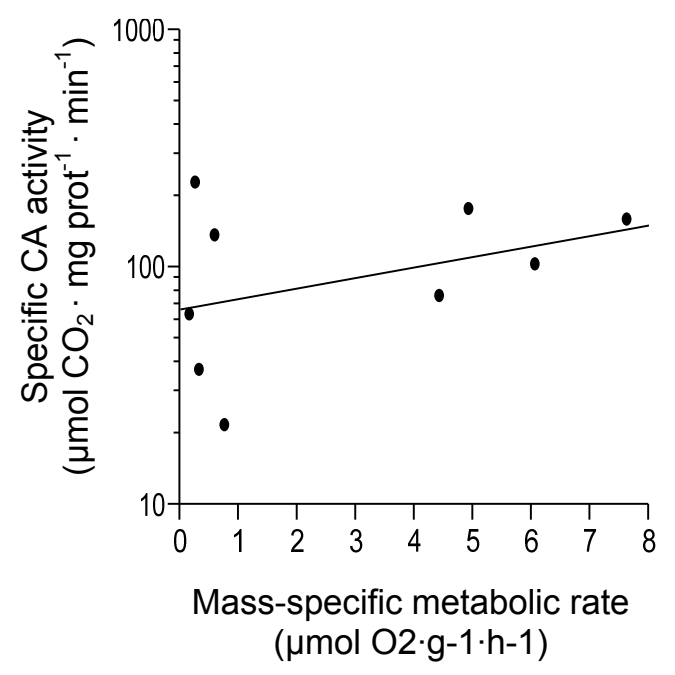

Figure 6. The scaling of CA activity as a function of mass-specific metabolic rate in individual species of cephalopods. A significant relationship exists between total CA activity and the metabolic rates among cephalopods distributed at different depths (A) (redrawn from Nyack, PhD dissertation, chapter 2), however, this relationship is no longer significant when specific CA activity was compared to metabolic rate in the same animals (B) (specific CA activity $=0.1 \mathrm{MR}+4.2, \mathrm{P}=0.30, r^{2}=0.15$ ). 
as throughout this study (Fig 6B). The correlation between weighted mean specific CA activity and weighted mean metabolic rate among families within Bivalvia (Fig. 7A) and decapod crustaceans (Fig. 7B) was not significant.

A

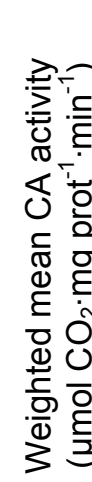

B

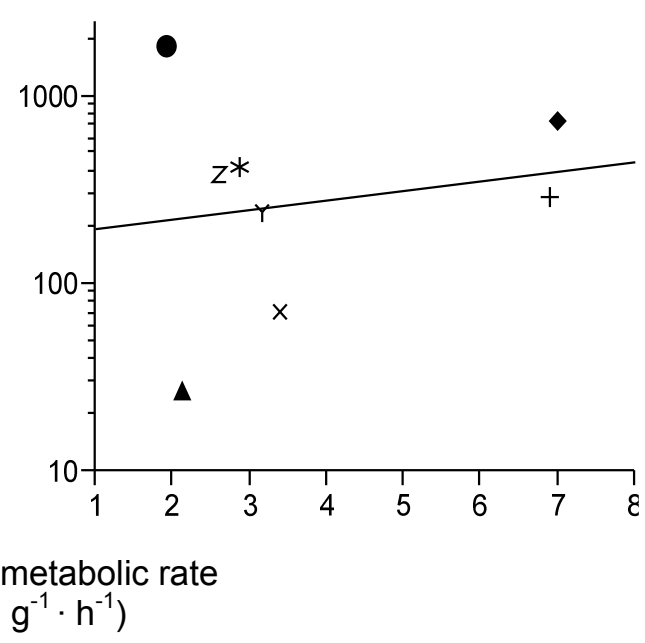

Figure 7. The weighted mean specific CA activity (y) as a function of weighted mean metabolic rate (MR) in bivalve (A) and decapod (B) families. A) There was not a significant correlation between weighted mean $\mathrm{CA}$ activity and either metabolic rate $\left(\mathrm{y}=-0.78 \mathrm{MR}+5.38, \mathrm{P}=0.11, r^{2}=0.51\right)$. Symbols represent bivalve families as follows: Corbiculidae $(\diamond)$, Vesicomyidae $(+)$, Lucinidae $(\Delta)$, Unionidae $(\mathrm{x})$, Solemyoida $(*)$, Mytilidae (•). B) There was also no relationship between the weighted mean specific $\mathrm{CA}$ activity among decapod families versus weighted mean metabolic rate $(\mathrm{MR})\left(\mathrm{y}=0.12 \mathrm{MR}+5.16, \mathrm{P}=0.67, r^{2}=0.03\right)$. Symbols represent decapod families as follows: Astacidae $(\bullet)$, Pisidae $(\mathbf{\Lambda})$, Portunidae $(\mathrm{Z})$, Varunidae $(*)$, Penaeidae (Y), Geryonidae (X), Cancirdae (+), Gecarcinidae ( $)$.

To thoroughly investigate any residual scaling trends the correlation between weighted mean CA activity and weighted mean metabolic was examined at other taxonomic levels. A significant inverse relationship was revealed between the weighted mean specific CA activity and weighted mean metabolic rate among bivalves (Fig. $8 \mathrm{P}=0.0002, r^{2}=0.7$ ). This trend seems to be independent of habitat 
Table 3. Weighted mean values for CA activity, mass, and metabolic rates (MR). Weighted measures were summed at the family level within each group. Values are means \pm SEM. $n$-values are the total number of specimens used in published experiments within each family.

\begin{tabular}{|c|c|c|c|c|c|c|c|c|c|}
\hline \multirow{3}{*}{$\begin{array}{l}\text { Phylum } \\
\text { Arthropoda }\end{array}$} & \multirow{3}{*}{$\begin{array}{l}\text { Class } \\
\text { Malacostraca }\end{array}$} & \multirow{3}{*}{$\begin{array}{l}\text { Order } \\
\text { Decapoda }\end{array}$} & \multirow{3}{*}{$\begin{array}{l}\text { Family } \\
\text { Portunidae }\end{array}$} & \multicolumn{3}{|c|}{ (umol CO2/mg prot/min) } & \multicolumn{3}{|c|}{ (umol O2/g/h) } \\
\hline & & & & $\underline{\mathrm{n}}$ & \multicolumn{2}{|c|}{ Mean \pm sem } & $\underline{\mathrm{n}}$ & \multicolumn{2}{|c|}{ Mean \pm sem } \\
\hline & & & & 93 & 383.89 & \pm 23.0 & 231 & 2.61 & \pm 0.11 \\
\hline & & & Pisidae & 8 & 26.99 & \pm 4.98 & 14 & 2.14 & \pm 0.11 \\
\hline & & & Gecarcinidae & 54 & 711.99 & \pm 131.4 & 97 & 7.02 & \pm 0.07 \\
\hline & & & Varunidae & 33 & 427.37 & \pm 24.51 & 25 & 2.87 & \pm 0.2 \\
\hline & & & Astacidae & 13 & 1846.62 & \pm 191.3 & 1 & 1.92 & ----- \\
\hline & & & Geryonidae & 12 & 70.17 & \pm 14.86 & 18 & 3.38 & \pm 0.15 \\
\hline & & & Cancridae & 6 & 288.63 & \pm 36.8 & 25 & 6.89 & \pm 0.64 \\
\hline & & & Penaeidae & 6 & 244.54 & \pm 84.81 & 188 & 3.16 & \pm 0.05 \\
\hline & Merostomata & Xiphosura & Limulidae & 6 & 266.42 & \pm 95.61 & 81 & 9.37 & \pm 0.28 \\
\hline \multirow[t]{2}{*}{ Cnidaria } & Anthozoa & Actinaria & Actiniidae & 6 & 0.91 & \pm 0.18 & 60 & 0.06 & \pm 0.01 \\
\hline & Schyphozoa & Rhizostomeae & Cassiopeidae & 2 & 6.63 & \pm 2.42 & 9 & 0.93 & \pm 0.06 \\
\hline Annelida & Polychaeta & Sabellida & Siboglinidae & 39 & 23.21 & \pm 3.94 & 107 & 15.26 & \pm 1.23 \\
\hline
\end{tabular}


Table 3 (continued)

\begin{tabular}{|c|c|c|c|c|c|c|c|c|c|}
\hline \multirow{3}{*}{$\begin{array}{l}\text { Phylum } \\
\text { Mollusca }\end{array}$} & \multirow{3}{*}{$\begin{array}{l}\text { Class } \\
\text { Bivalvia }\end{array}$} & \multirow{3}{*}{$\begin{array}{l}\text { Order } \\
\text { Veneroida }\end{array}$} & \multirow{3}{*}{$\begin{array}{l}\text { Family } \\
\text { Corbiculidae }\end{array}$} & \multicolumn{3}{|c|}{$\begin{array}{l}\text { CA activity } \\
\text { (umol CO2/mg prot/min) }\end{array}$} & \multicolumn{3}{|c|}{$\begin{array}{c}\text { MR } \\
\text { (umol O2/g/h) }\end{array}$} \\
\hline & & & & $\underline{\mathrm{n}}$ & \multicolumn{2}{|c|}{ Mean \pm sem } & $\underline{\mathrm{n}}$ & \multicolumn{2}{|c|}{ Mean \pm sem } \\
\hline & & & & 1 & 580.9 & -------- & 26 & 0.87 & \pm 0.03 \\
\hline & & & Vesicomyidae & 10 & 90.27 & \pm 12.92 & 37 & 1.85 & \pm 0.19 \\
\hline & & & Lucinidae & 5 & 13.45 & \pm 5.1 & 18 & 0.22 & \pm 0.19 \\
\hline & & Unionoida & Unionidae & 8 & 208.03 & \pm 37.28 & 17 & 1.67 & \pm 0.12 \\
\hline & & Mytiloida & Mytilidae & 12 & 1.79 & \pm 0.21 & 35 & 4.71 & \pm 0.44 \\
\hline & & Solemyoida & Solemyidae & 3 & 4.44 & \pm 0.46 & 30 & 5.29 & \pm 0.25 \\
\hline & Cephalopoda & Teuthida & Loliginidae & 19 & 252.97 & \pm 25.58 & 153 & 15.94 & \pm 0.29 \\
\hline & & & Ommastrephidae & 2 & 78.97 & \pm 19.05 & 170 & 17.62 & \pm 0.65 \\
\hline & & & Chiroteuthidae & 4 & 294.86 & \pm 27.21 & 13 & 1.62 & \pm 0.09 \\
\hline & & & Cranchiidae & 5 & 162.34 & \pm 34.35 & 38 & 1.67 & \pm 0.07 \\
\hline & & & Gonatidae & 4 & 46.6 & \pm 5.24 & 30 & 12.1 & \pm 0.92 \\
\hline & & & Histioteuthidae & 2 & 136.03 & \pm 126.5 & 23 & 2.43 & \pm 0.09 \\
\hline & & & Mastigoteuthidae & 4 & 482.16 & \pm 240.3 & 5 & 2.98 & \pm 0.6 \\
\hline & & Octopoda & Bolitaenidae & 9 & 342.96 & \pm 60.0 & 54 & 1.63 & \pm 0.14 \\
\hline
\end{tabular}


or depth distribution. Species within Calyptogena exhibited specific CA activities and mean metabolic rates more similar to those of freshwater bivalves (L. subrostrata and C. fluminea) than to the other deep-sea bivalves, Bathymodiolus spp and S. reidi. It should be noted, however, that our result from the analysis of higher nodes indicates that genera within bivalve families should not be considered independent from each other. However, the only family that was represented by more than one genus was Mytilidae (Mytilus spp. and Bathymodiolus spp.)

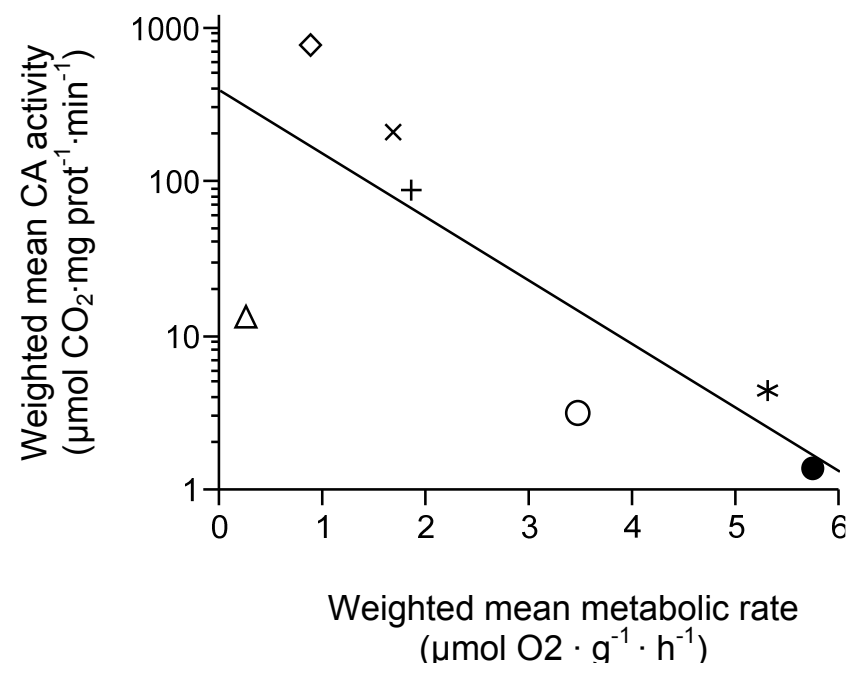

Figure 8. The scaling of the weighted specific CA activity (y) as a function of weighted mean metabolic rate (MR) among bivalves. All of the weighted mean values were calculated from species within a genus. There was a significant decline in weighted mean specific CA activity with increasing metabolic rate $(y=-0.87 \mathrm{MR}$ $\left.+5.47, \mathrm{P}=0.0002, r^{2}=0.7\right)$. Note that Calyptogena and Bathymodiolus, both bathyal bivalves, are on opposite ends of the distribution. Symbols represent species within families as follows: Corbicula fluminea $(\diamond)$, Calyptogena spp. $(+)$, Lucinoma aequizonata $(\Delta)$, Ligumia subrostrata $(\mathrm{x})$, Solemya reidi $(*)$, Mytilus californianus $(\circ)$ and Bathymodiolus spp. (•). 


\section{Discussion}

\subsection{Taxonomic differences in specific CA activity}

There were significant differences in the specific CA activity among taxonomic groups at the phylum, class, and order levels when the recalculated mean reported specific CA activity values for all species sampled was analyzed. In some active animals the difference between species may be due to the amount of total protein content within the respiratory tissues. A number of the squids included in this study (e.g. Ommastrephidae) are muscular, active swimmers with high metabolic rates (Seibel, 2007). However, the specific CA activity of the ommatrephid species examined (Dosidicus gigas) was among the lowest of the teuthid squids. In some instances the difference in specific CA activities between taxonomic groups may be related to the activity of animals within a group. For example, the mean values for sessile annelids and cnidarians were all similar to each other and much lower than the activity in molluscs and arthropods. The observed differences between taxonomic groups at various levels are probably due to the demands an organisms' habitat places on it to maintain homeostasis.

\subsection{Differences in specific CA activity due to habitat}

The specific CA activity in an organisms' respiratory tissue has a clear correlation with its habitat. The elevated activities within Arthropoda were largely due to by terrestrial and semi-terrestrial decapod species (Fig. 4), and the euryahline crayfish, Pacifasticus lenisculus (Astacidae) (Fig. 2). In the terrestrial species, high CA activity has been attributed to either ion regulation (Morris and Greenaway, 1990) 
or elevated metabolic rate (Henry, 1991b). The published specific CA activities used here for the group of decapods labeled as 'euryhaline' were all acclimated to 29-35 ppt, salinities that do not induce differential upregulation of CA activity between the gill arches in these animals (Henry and Cameron, 1982a). The exception to this was $P$. leniusculus (Astacidae), of which the values used here were from animals caught and maintained in freshwater (Wheatly and Henry, 1987) and the highest values in the data set (Table 1). Exclusion of the P. leniusculus did not change the results of the analyses, i.e. result in a significant difference in specific CA activity between terrestrial and euryhaline arthropods. In fact, acclimation to higher salinity treatments (15 and $25 \mathrm{ppt}$ ) led to reductions in specific activity of CA in the gills of $P$. leniusculus (Wheatly and Henry, 1987). The effect of habitat on specific CA activity is also illustrated by the activity among osmoregulating freshwater bivalves. CA in this group is important in ion regulation (Henry and Saintsing, 1983), but the specific activity is comparable to isosmotic squids.

\subsection{Specific CA activity in cytoplasm versus crude homogenate}

The observed differences in specific CA activity between taxa versus habitat could also be an artifact of the fraction used in the assay. The majority of the studies that met the inclusion criteria measured specific CA activity in either the cytoplasmic fraction (i.e. cell debris and mitochondria were removed by centrifugation), or were from crude homogenate (Fig. 5). Within the full dataset, only reported values for the class Bivalvia had sufficient sample size to analyze the differences in these two fractions, and showed that cytoplasmic activity was significantly greater than crude 
homogenate ( $\mathrm{t}$-test, $\mathrm{P}=0.0042$ ). The difference between these two fractions, however, may be correlated to differences in habitat of the study animals instead of the fraction. All of the studies that used crude homogenate to measure specific CA activity were performed on marine bivalves, which demonstrated low specific CA activity (39.9 $\mu \mathrm{mol} \mathrm{CO} 2 \cdot \mathrm{mg} \mathrm{prot}^{-1} \cdot \min ^{-1}$ at $\left.15^{\circ} \mathrm{C}\right)$.

Some studies in crustaceans separated the cytoplasmic fraction to measure the activity in the microsomal and cytosolic subcellular compartments (Henry, 1988; Henry 1991b; López Mañanes et al., 2000). The activities in these fractions were combined for the purposes of our comparisons since other studies in the dataset did not separate these subcellular compartments. While the CA activity in the subcellular fraction may be significant for some crustacean species, Weis (1993) showed that the specific CA activity in crude homogenate and soluble (cytoplasmic) fraction in A. pulchella were statistically the same. Crude homogenates probably contains more total protein than when the homogenate is separated by differential centrifugation. If the increase in protein concentration from inclusion of the mitochondria (which contain their own CA isozyme) and cell debris fractions is greater than the difference in CA activity, then the specific are likely underestimates of the specific CA activity.

\subsection{Presence of symbionts}

The majority of cnidarian species and the deep-sea annelids (Siboglinidae) and bivalves (Vesicomyids and Bathymodiolus spp.) used in the full dataset contained endosymbionts that aid in carbon fixation. Our analysis did not show a significant difference in the specific CA activity between symbiotic and asymbiotic species 
among values reported in the literature. The lack of significance may have been due to a large standard error associated with the specific CA activity values reported for asymbiotic organisms among the studies included in the dataset. Further, our results contrast the findings of some of the individual studies. For example, Weis et al. (1989) found significantly greater specific CA activity in the animal tissue of zooxanthellate cnidarians despite examining the CA activity in very few azooxanthellate species. Kochevar and Childress (1996) demonstrated higher values in vesicomyid gills and the plumes of siboglinid worms. However, there was large variability in the activity for most species they measured and sample sizes were typically three or less. While the findings in the present study pertain to only the results of the literature sampled here, both our results comparing specific CA activity and those in the original studies should be considered carefully.

\subsection{Weighted mean specific CA activity and metabolic rate}

Using a subsample of the full CA dataset, we examined the weighted mean specific CA activity, metabolic rate, and animal mass to investigate any residual scaling trends. The results of an analysis of higher nodes indicated that the specific CA activity data for most phyla were independent between families within an order. Massspecific metabolic rates tend to decline with increasing body mass (e.g. Kleiber, 1932; Schmidt-Nielsen, 1984; Seibel, 2007). Similarly, aerobic enzymes in gill and muscle tissues also tend to scale negatively with body mass (Childress and Somero, 1990; Seibel, 2007; Kinsey et al., 2003), reflecting the trend in metabolic rate scaling. Thus, larger organisms with low metabolic rate also tend to have low oxidative enzyme 
activity and vice versa. For example, the total CA activity $\left(\mu \mathrm{mol} \mathrm{CO}{ }_{2} \cdot \mathrm{g}\right.$ animal $^{-1} \cdot \mathrm{min}^{-}$ ${ }^{1}$ ) in cephalopod gill tissue is correlated with metabolic rate (Fig. 6A), but specific CA activity is not (Fig. 6B). However, using specific activity of CA as the basis of comparison among animals from different phyla has the advantage of mitigating the effects of animal mass and metabolic rate between otherwise disparate groups. The lack of a correlation between weighted mean specific CA activity and weighted mean metabolic rate and animal mass among families within orders Malacostraca and Bivalvia appears to support this (Fig. 7).

The only significant correlation found was a strong inverse relationship between weighted mean specific CA activity and weighted mean metabolic rate among bivalve genera (Fig. 8). That the specific CA activity of some hydrothermal vent clams (Calyptogena spp. and L. aequizonata) is similar to that of the freshwater species C. fluminea and $L$. subrostrata suggests that CA activity might be more influenced by habitat demands than metabolic rate. The activity of $\mathrm{CA}$ in the freshwater species has been attributed to the osmotic demands of their environment (Henry and Saintsing, 1983). Calyptogena spp. and L. aequizonata, however, have similar depth distributions to the clam S. reidi and mussels Bathymodiolus spp. and are often sympatric (Kochevar and Childress, 1996; Fisher et al., 1988a). However, Calyptogena spp., like other Vesicomyid clams, has hemoglobin in its circulatory system to transport oxygen, supplies its endosymbiotic bacteria in the gills with both $\mathrm{H}_{2} \mathrm{~S}$ and $\mathrm{S}_{2} \mathrm{O}_{3}{ }^{2-}$ chemoautotrophy and uptake mechanism (Arp et al., 1984; Childress et al, 1991; reviewed in Childress and Girguis, 2011). Vesicomyid clams have a reduced digestive tract and rely heavily on their endosymbionts (Fisher et al., 1988b), 
which they digest (Childress and Girguis, 2011), suggesting relatively rapid turnover rate of endosymbiotic bacteria in these animals. The high specific activity of gill CA in this group may be needed to not only facilitate ambient $\mathrm{CO}_{2}$ uptake (Kochevar and Childress, 1996), but also the dehydration of circulatory bicarbonate to supply sufficient carbon to the endosymbionts in order to sustain the population. C. magnifica, and probably other vesicomyid clams, flourishes in narrower conditions than other vent bivalves, such as Bathymodiolus thermophilus (Fisher et al., 1988b,c). This sensitivity to changes in their environment suggests that another reason for the higher specific CA activity in the vesicomyids compared to B. thermophilis could be due to shell deposition.

\subsection{Conclusions}

The enzyme CA is a physiologically important enzyme in that it both maintains the instantaneous equilibrium of $\mathrm{CO}_{2}$ and $\mathrm{HCO}_{3}{ }^{-}$and assists in several other key homeostatic processes. In the present study we collected data from the literature that reported specific CA activity in respiratory tissues for a broad group of invertebrates to examine the factors underlying differences in CA activity. Our results suggest that when the effects of animal mass and metabolic rate are removed, the specific CA activity is are strongly correlated with the demands of an organisms' habtat. The fact that CA is strongly influenced by habitat and environmental factors in invertebrate respiratory tissue suggests that this enzyme should be included in studies that investigate impacts of climate change. It is important to keep in mind that the findings presented here pertain to natural variation in specific CA activity from studies 
that met our particular inclusion criteria. However, the accruing body of CA literature in invertebrates could generate future meta-analyses that examine the effects of environmental conditions (e.g. climate change) on CA across species. 


\section{Literature Cited (NOTE: this includes citations for data sources)}

Anderson, A.E., Childress, J.J., and J.A. Favuzzi. (1987). Net uptake of $\mathrm{CO}_{2}$ driven by sulfide and thiosulfate oxidation in the bacterial symbiontcontaining clam Solemya reidi. J. Exp. Biol. 133: 1-31.

Arndt-Sullivan, C., Lechaire, J-P., and H. Felbeck. (2008). Extreme tolerance to anoxia in the Lucinoma aequizonata symbiosis. J. Shell. Res. 27: 119-127.

Arp, A.J., Childress, J.J., and C.R. Fisher. (1984). Metabolic and gas transport characteristics of the hydrothermal vent bivalve Calyptogena magnifica. Physiol. Zool. 57: 648-662.

Badger, M.R. and G.D. Price. (1994). The role of carbonic anhydrase in photosynthesis. Ann. Rev. Plant Physiol. Plant Mol. Biol. 45: 369-392.

Bartol, I.A., Mann, R., and M.R. Patterson. (2001). Aerobic respiratory costs of swimming in the negatively buoyant brief squid Lolliguncula brevis. J. Exp. Biol. 204: 3639-3653.

Bartol, I.K., Mann, R., and M. Vecchione. (2002). Distribution of the euryhaline squid Lolliguncula brevis in Chesapeake bay: effects of selected abiotic factors. Mar. Ecol. Prog. Ser. 226: 235 - 247.

Belanger, S.E. (1991). The effect of dissolved oxygen, sediment, and sewage treatment plant discharge upon growth, survival and density of Asiatic clams. Hydrobologia. 218: 113-126.

Bertucci, A., Moya, A., Tabutte, S., Allemand, D., Supuran, C.T., and D. Zoccola. (2013). Carbonic anhydrase in anthozoan coals - a review. Bioorg. Medic. Chem. 21: 1437-1450.

Booth, C.E. and B. R. McMahon. (1985). Lactate dynamics during locomotor activity in the blue crab, Callinectes sapidus. J. Exp. Biol. 118: 461-465.

Booth, C.E. and B.R. McMahon. (1992). Aerobic capacity of the blue crab, Callinectes sapidus. Physiol. Zool. 65: 1074-1091.

Booth, C.E., McMahon, B.R., and A.W. Pinder. (1982). Oxygen uptake and the potential effects of increased hemolymph lactate on oxygen transport during exercise in the blue crab, Callinectes sapidus. J. Comp. Physiol. 148: 111-121.

Böttcher, K., Siebers, D., and W. Becker. (1990a). Carbonic anhydrase in branchial tissues of osmoregulating shore crabs, Carcinus maenas. J. Exp. Zool. 255: 251-261. 
Böttcher, K., Siebers, D., and W. Becker. (1990b). Localization of carbonic anhydrase in the gills of Carcinus maenas. Comp. Biochem. Physiol. 96B: 243246.

Böttcher, K., and D. Siebers. (1993). Biochemistry, localization, and physiology of carbonic anhydrase in the gills of euryhaline crabs. J. Exp. Zool. 265: 397-409.

Boucher-Rodoni, R. and K. Mangold. (1989). Respiration and nitrogen excretion by the squid Loligo forbesi. Mar. Biol. 103: 333-338.

Boucher-Rodoni, R. and K. Mangold. (1994). Ammonia production in Cephalopods, physiological and evolutionary aspects. In: Physiology of Cephalopod Molluscs: Lifestyle and Performance Adaptations. Eds. Pörtner, H.O., O'Dor, R.K., and Macmillan, D.L.Gordon and Breach Science Publishers S.A., U.S. pp 53-60.

Bradford, S.M. and A.C. Taylor. (1982). The respiration of Cancer pagarus under normoxic and hypoxic conditions. J. Exp. Biol. 97: 273-288.

Brinkman, R. (1933). The occurrence of carbonic anhydrase in lower marine animals. J. Physiol. 80: 171-173.

Burggren, W.W., Moreira, G.S., and M.C.F. Santos. (1993). Specific dynamic action and the metabolism of the brachyuran land crabs Ocypode quadrata (Fabricius, 1787), Goniopsis cruentata (Latreille, 1803), and Cardisoma guanhumi Latreille, 1825. J. Exp. Mar. Biol. Ecol. 169: 117-130.

Burnett, L.E. (1979). The effects of environmental oxygen levels on the respiratory function of hemocyanin in the crabs, Libinia emarginata and Ocypode quadrata. J. Exp Zool. 210: 289-300.

Burnett, L.E., Woodson, P.B.J., Rietow, M.G., and V.C. Vilicich. (1981). Crab gill intra-epithelial carbonic anhydrase plays a major role in haemolymph $\mathrm{CO}_{2}$ and chloride ion regulation. J. Exp. Biol. 92: 243-254.

Byrne, R.A., Gnaiger, E., McMahon, R.F., and T.H. Dietz. (1990). Behavioral and metabolic responses to emersion and subsequent reimmersion in the freshwater bivalve, Corbicula fluminea. Biol. Bull. 178: 251-259.

Childress, J.J. and T.J. Mickel. (1982). Oxygen and sulfide consumption rates of thevent clam Calyptogena pacifica. Mar. Biol. Lett. 3: 73-79.

Childress, J.J. and P.R. Girguis. (2011). The metabolic demands of endosymbiotic chemoautotrophic metabolism on host physiological capacities. J. Exp. Biol. 214: $312-325$. 
Childress, J.J. and G.N. Somero. (1990). Metabolic scaling: a new perspectives based on scaling glycolytic enzyme activities. Amer. Zool. 30: 161-173.

Childress, J.J., Arp, A.J., and C.R. Fisher. (1984). Metabolic and blood characteristics of the hydrothermal vent tube-worm Riftia pachyptila. Mar. Biol. 83: 109-124.

Childress, J.J., Fisher, C.R., Favuzzi, J.A. and K.N. Sanders. (1991). Sulfide and carbon dioxide uptake by the hydrothermal vent clam, Calyptogena magnifica, and its chemoautotrophic symbionts. Phyiol. Zool. 64: 1444-1470.

Childress, J.J., Fisher, C.R., Favuzzi, J.A., Arp, A.J., and D.R. Oros. (1993). The role of a zinc-based, serum-borne sulfide-binding component in the uptake and transport of dissolved sulphide by the chemoautotrophic symbiontcontaining clam Calyptogena elongata. J. Exp. Biol. 179: 131-158.

Coan, E.V. and P. Valentich-Scott. (2012). Bivalve seashells of tropical West America: marine bivalve mollusks from Baja California to northern Peru. Santa Barbara Museum of Natural History. Santa Barbara, Calif. 1258 pp.

Dietz, T.H. (1974). Body fluid composition and aerial oxygen consumption in the freshwater mussel, Ligumia subrostrata (Say): effects of dehydration and anoxic stress. Biol. Bull. 147: 560-572.

Engels, E.A., Falagas, M.E., Lau, J. and M.L. Bennish. (1998). Typhoid fever vaccines: a meta-analysis of studies on efficacy and toxicity. Brit. Med. J. 316: 110-116.

Fehsenfeld, S. and D. Weihrauch. (2013). Differential acid-base regulation in various gills of the green crab Carcinus maenas: effects of elevated environmental $\mathrm{pCO}_{2}$. Comp. Biochem. Physiol. 164A: 54-65.

Finke, E., Pörtner, H.O., Lee, P.G., and D.M. Webber. (1996). Squid (Lolliguncula brevis) life in shallow water: oxygen limitation of metabolism and swimming performance. J. Exp. Biol. 199: 911-921.

Fisher, C.R., Childress, J.J., Arp, A.J., Brooks, J.M., Distel, D., Favuzzi, J.A., Macko, S.A., Newton, A., Powell, M.A., Somero, G.N., and T. Soto. (1988a). Physiology, morphology, and biochemical composition of Riftia pachyptila at Rose Garden in 1985. Deep-sea Res. 35: 1745-1758. 
Fisher, C.R., Childress, J.J., Arp, A.J., Brooks, J.M., Distel, D.L., Dugan, J.A., Felbeck, H., Fritz, L.W., Hessler, R.R., Johnson, K.S., Kennicutt, M.C., Lutz, R.A., Macko, S.A., Newton, A., Powell, M.A., Somero, G.N., and T. Soto. (1988b). Variation in the hydrothermal vent clam, Calyptogen magnifica, at the Rose Garden vent on the Galapagos spreading center. Deep-sea Res. 35: 18111831.

Fisher, C.R., Childress, J.J., Arp, A.J., Brooks, J.M., Distel, D., Favuzzi, J.A., Felbeck, H., Hessler, R.R., Johnson, K.S., Kennicutt, M.C., Macko, S.A., Newton, A., Powell, M.A., Somero, G.N., and T. Soto. (1988c). Microhabitat variation in the hhydrothermal vent mussel, Bathymodiolus thermophilus, at the Rose Garden vent on the Galapagos Rift. Deep-sea Res. 35: 1769-1791.

Fitt, W.K. and R.L. Pardy. (1981). Effects of starvation, and light and dark on the energy metabolism of symbiotic and aposymbiotic sea anemones, Anthopleura elegantissima. Mar. Biol. 61: 199-205.

Fitt, W.K., Pardy, R.L., and M.M. Littler. (1982). Photosynthesis, respiration, and contribution to community productivity of the symbiotic sea anemone Anthopleura elegantissima (Brandt, 1835). J. Exp Mar. Biol. Ecol. 61: 213232.

Freeman, J.A. and K.M. Wilbur. (1948). Carbonic anhydrase in molluscs. Bio. Bull. 94: 55-59.

Freytag, J.K., Girguis, P.R., Bergquist, D.C., Andras, J.P., Childress, J.J., and C.R. Fisher. (2001). A paradox resolved: Sulfide acquisition by roots of seep tubeworms sustains net chemoautotrophy. Proc. Natl. Acad. Sci. 98: 1340813413.

Furla, P., Allemand, D., M-A. Orsenigo. (2000). Involvement of $\mathrm{H}^{+}$-ATPase and carbonic anhydrase in inorganic carbon uptake for endosymbiont photosynthesis. Am. J. Physiol. 278: R870-R881.

Gannon, A.T. Arunakul, N., and R.P. Henry. (2001). Respiratory, cardiovascular, and hemolymph acid-base changes in the amphibious crab, Cardisoma guanhumi, during immersion and emersion. Mar. Freshw. Behav. Physiol. 34: 73-92.

Geihs, M.A., Maciel, F.E., Vargas, M.A., Cruz, B.P., and L.E.M. Nery. (2013). Effects of hypoxia and reoxygenation on the energetic metabolism of the crab Neohelice granulata (Decapoda, Varunidae). J. Exp. Mar. Biol. Ecol. 445: 6978. 
Georgalis, T., Perry, S.F., and K.M. Gilmour. (2006). The role or branchial carbonic anhydrase in acid-base regulation in rainbow trout (Oncorhynchus mykiss). J. Exp. Biol. 209: 5181-530.

Genovese, G., Ortiz, N., Urcola, M.R. and C.M. Luquet. (2005). Possible role of carbonic anhydrase, $\mathrm{V}-\mathrm{H}^{+}$-ATPase, and $\mathrm{Cl}^{-} / \mathrm{HCO}_{3}{ }^{-}$exchanger in electrogenic ion transport across the gills of the euryhaline crab Chasmagnathus granulatus. Comp. Biochem. Physiol. 142A: 362-369.

Gilmour, K.M., (2012). New insights into the many functions of carbonic anhydrase in fish gills. Respir. Physiol. Neurobiol. 184: 223-230.

Gilmour, K.M. and S.F. Perry. (2009). Carbonic anhydrase and acid-base regulation in fish. J. Exp. Biol. 212: 1647-1661.

Girguis, P.R., Childress, J.J., Freytag, J.K., Klose, K., and R. Stuber. (2002). Effects of metabolite uptake on proton-equivalent elimination by two species of deep-sea vestimentiferan tubeworm, Riftia pachyptila and Lamellibrachia cf luymesi: proton elimination is a necessary adaptation to sulfide-oxidizing chemoautotrophic symbionts. J. Exp. Biol. 205: 3055-3066.

Girguis, P.R. and J.J. Childress. (2006). Metabolic uptake, stoichiometry and chemoautotrophic function of the hydrothermal vent tubeworm Riftia pachyptila: responses to environmental variation in substrate concentrations and temperature. J. Exp. Biol. 209: 3516-3528.

Goffredi, S.K., Childress, J.J., Desaulnier, N.T., Lee, R.W., Lallier, F.H. and D. Hammond. (1997). Inorganic carbon acquisition by the hydrothermal vent tubeworm Riftia pachyptila depends upon high external $\mathrm{P}_{\mathrm{CO}_{2}}$ and upon proteinequivalent ion transport by the worm. J. Exp. Biol. 200: 883-896.

Goffredi, S.K., Girguis, P.R., Childress, J.J., and N.T. Desaulniers. (1999). Physiological function of carbonic anhydrase in the hydrothermal vent tubeworm Riftia pachyptila. Biol. Bull. 196: 257-264.

Glass, G.V. (1976). Primary, secondary, and meta-analysis of research. Educ. Res. 5: $3-8$.

Graney, R.L. and J.P. Giesy. (1988). Alterations in the oxygen consumption, condition index and concentration of free amino acids in Corbicula fluminea (Mollusca: Pelecypoda) exposed to sodium dodecyl sulfate. Enviro. Toxicol. Chem. 7: 301-315.

Grosell, M., Gilmour, K.M., and S.F. Perry. (2007). Intestinal carbonic anhydrase, bicarbonate, and proton carriers play a role in the acclimation of rainbow trout to seawater. Am. J. Physiol. 293R: 2099-2111. 
Grosell, M., Genz, J., Taylor, J.R., Perry, S.F., and K.M. Gilmour. (2009). The involvement of $\mathrm{H}^{+}$-ATPase and carbonic anhydrase in intestinal $\mathrm{HCO}_{3}{ }^{-}$ secretion in seawater acclimated rainbow trout. J. Exp. Biol. 212: 1940-1948.

Gustafson, R.G., Turner, R.D. Lutz, R.A. and R.C. Vrijenhoek. (1998). A new genus and five new species of mussels (Bivalvia, Mytilidae) from the deep-sea sulfide/hydrocarbon seeps in the Gulf of Mexico. Malacologia 40: 63-112.

Halperin, J., Ansaldo, M., Pellerano, G.M., and C.M. Luquet. (2000). Bimodal breathing in the estuarine crab, Chasmagnathus granulatus Dana 1851-physiological and morphological studies. Comp. Biochem. Physiol. 126A: 341349.

Harland, A.D. and P.S. Davies. (1995). Symbiont photosynthesis increases both respiration and photosynthesis in the symbiotic sea anemone Anemonia viridis. Mar. Biol. 123: 715-722.

Harvey, P.H. and M.D. Pagel. (1991). The Comparative Method in Evolutionary Biology. Oxford University Press, New York. 239p.

Havird, J.C., Henry, R.P., and A.W. Wilson. (2013). Altered expression of $\mathrm{Na}^{+} / \mathrm{K}^{+}$ -ATPase and other osmoregulatory genes in the gills of euryhaline animals in response to salinity transfer: a meta-analysis of 59 quantitative PCR studies over 10 years. Comp. Biochem. Physiol. 8D: 131-140.

Hedges, L.V. (1982). Estimation of effect size from a series of independent experiments. Psychol. Bull. 92: 490-499.

Hedges, L.V., Laine, R.D. and R. Greenwald. (1994). An exchange: part I: Does money matter? A meta-analysis of the effects of differential school inputs on student outputs. Ed. Res. 23: 5-14.

Hedges, L.V., Gurevitch, J. and Curtis, P.S. (1999). Themeta-analysisof response ratios in experimental ecology. Ecology. 80: 1150-1156.

Hendrix, J.P., Hulet, W.H., and M.J. Greenberg. (1981). Salinity tolerance and the response to hypoosmotic stress of the bay squid Lolliguncula brevis, a euryhaline cephalopod mollusc. Comp. Biochem. Physiol. A 69: 641-648.

Henry, M.S., Childress, J.J., and D. Figueroa. (2008). Metabolic rates and thermal tolerances of chemoautotrophic symbioses from Lau Basin hydrothermal vents and their implications for species distributions. Deep-sea Res. I 55: 679-695.

Henry, R.P. (1988b). Subcellular distribution of carbonic anhydrase in the gills of the blue crab. Callinectes sapidus. J. Exp. Zool. 245: 1-8. 
Henry, R.P. (1991a). Techniques for measuring carbonic anhydrase activity in vitro: The electrometric delta $\mathrm{pH}$ method and the $\mathrm{pH}$ stat method. In: The Carbonic Anhydrases: Cellular, Phyiology, and Molecular Genetics (eds. S.J. Dodgson, R.E. Tashian, G. Gros and N.D. Carter), New York: Plenum. pp. 119 -125 .

Henry, R.P. (1991b). Branchial and branchiostegite carbonic anhydrase in decapod crustaceans: the aquatic to terrestrial transition. J. Exp. Zool. 259: 294-303

Henry, R.P. (1996). Multiple roles of carbonic anhydrase in cellular trasnport and metabolism. Annu. Rev. Physiol. 58: 523-538.

Henry, R.P. (2001). Environmentally mediated carbonic anhydrase induction in the gills of euryhaline crustaceans. J. Exp. Biol. 204: 991 - 1002.

Henry, R.P. (2005). Critical salinity, sensitivity, and commitment of salinitymediated carbonic anhydrase induction in the gills of two euryhaline species of decapod crustaceans. J. Exp. Zool. 303: 45-56.

Henry, R.P., Lucu, C., Onken, H., and D. Weihrauch. (2012). Multiple functions of the crustacean gill: osmotic/ionic regulation, acid-base balance, ammonia excretion, and bioaccumulation of toxic metals. Front. Physiol. 3: 1-33.

Henry, R.P. and J.N. Cameron. (1982a). The distribution and partial characterization of carbonic anhydrase in selected aquatic and terrestrial decapod crustaceans. J. Exp. Zool. 221: 309-321.

Henry, R.P. and J.N. Cameron. (1982b). Acid-base balance in Callinectes sapidus during acclimation from high to low salinity. J. Exp. Biol. 221: 309-321.

Henry, R.P. and J.N. Cameron. (1983). The role of carbonic anhydrase in respiration, ion regulation and acid-base balance in the aquatic crab Callinectes sapidus and the terrestrial crab, Gecarcinus lateralis. J. Exp. Biol. 103: 205223.

Henry, R.P. and D.G. Saintsing. (1983). Carbonic anhydrase activity and ion regulation in three species of osmoregulating bivalve molluscs. Physiol Zool. 56: $274-280$.

Henry, R.P. and M.G. Wheatly. (1988). Dynamics of salinity adaptations in the euryhaline crayfish Pacifasticus leniusculus. Physiol. Zool. 61: 260-271.

Henry, R.P. and S.A. Watts. (2001). Early carbonic anhydrase induction in the gills of the blue crab, Callinectes sapidus, durling low salinity acclimation is independent of ornithine decarboxylase activity. J. Exp. Zool. 289: 350-358. 
Henry, R.P. and D.W. Borst. (2006). Effects of eyestalk ablation on carbonic anhydrase activity in the euryhaline blue crab Callinectes sapidus: neuroendocrine control of enzyme expression. J. Exp. Zool. 305A: 23-31.

Henry, R.P. and M. Campoverde. (2006). Neuroendocrine regulation of carbonic anhydrase in the gills of the euryhaline green crab, Carcinus maenas. J. Exp. Zool. 305A: 663-668.

Henry, R.P., Perry, H.M., Trigg, C.B., Handley, H.L., and A. Karup. (1990a). Physiology of two species of deep-water crabs, Chaceon fenneri and $C$. quinquedens: gill morphology, hemolymph ionic and nitrogen concentrations. J. Crust. Biol. 10: 375-381.

Henry, R. P., Handley, H.L., Krarup, A., and H.M. Perry. (1990b). Respiratory and cardiovascular responses of two species of deep-sea crabs, Chaceron fenneri and C. quinquedens, in normoxia and hypoxia. J. Crust. Biol. 10: 413-422.

Henry, R.P. Jackson, S.A., and C.P. Mangum. (1996). Ultrastructure and transportrelated enzymes of the gills and coxal gland of the horseshoe crab Limulus polyphemus. Bio. Bull. 191: 241-250.

Henry, R.P., Garrelts, E.E., McCarty, M.M., and D.W. Towle. (2002). Differential induction of branchial carbonic anhydrase and $\mathrm{Na}^{+} / \mathrm{K}^{+}$ATPase activity in the euryhaline crab, Carcinus maenas, in response to low salinity exposure. J. Exp. Zool. 292: 595-603.

Henry, R.P., Gehnrich, S., Weihrauch, D., and D.W. Towle. (2003). Salinitymediated carbonic anhydrase induction in the euryhaline green crab, Carcinus maenas. Comp. Biochem. Physiol. 136A: 243-258.

Henry, R.P., Thomas, K.L., and D.W. Towle. (2006). Quantitative changes in branchial carbonic anhydrase activity and expression in the euryhaline green crab, Carcinus maenas, in response to low salinity exposure. J. Exp. Zool. 305A: $842-850$.

Hentschel, U., Millikan, D.S., Arndt, C., Cary, S.C., and H. Felbeck. (2000). Phenotypic variations in the gills of the symbiont-containing bivalve Lucinoma aequizonata. Mar. Biol. 136: 633-643.

Hofmann, L.C., Straub, S. and K. Bischof. (2013). Elevated $\mathrm{CO}_{2}$ levels affect the activity of nitrate reductase and carbonic anhydrase in the calcifying rhodophyte Corallina officinalis. J. Exp. Bot. 64: 899-908.

Huber, M. (2010). Compendium of bivalves. Conchbooks, Hackenheim 901pp. 
Hubery, C.J. (2002). A history of effect size indices. Educ. and Psychol. Measur. 62: $227-240$.

Jillett, N., Cammack, L., Lowenstein, M., and R.P. Henry. (2011). Downregulation of activity and expression of three transport-related proteins in the gills of the euryhaline crab, Carcinus maenas, in response to high salinity acclimation. Comp. Biochem. Physiol. 158A: 189-193.

Johansen, K., and J.A. Petersen. (1975). Respiratory adaptations in Limulus polyphemus (L.). In: Physiological Ecology of Estuarine Organisms, F.J. Vernberg, Ed. University of South Carolina Press, Colombus, South Carolina. pp. 129-146.

Kinsey, S.T., Buda, E. and J. Nordeen. (2003). Scaling of gill metabolic potential as a function of salinity in the euryhaline crab, Callinectes sapidus Rathburn. Physiol. Biochem. Zool. 76: 105-114.

Kleiber, M. (1932). Body size and metabolism. Hilgardia. 6: 315-352.

Kochevar, R.E., Childress, J.J., Fisher, C.R., and E. Minnich. (1992). The methane mussel: roles of symbiont and host in the metabolic utilization of methane. Mar. Biol. 112: 389-401.

Kochevar, R.E., and J.J Childress. (1996). Carbonic anhydrase in deep-sea chemoautotrphic symbioses. Mar. Biol. 125: 375-383.

Lamb, J.E. (1977). Plant carbonic anhydrase. Life Sci. 20: 393-406.

Leffler, C.W. (1972). Some effect of temperature on growth and metabolic rate of juvenile blue crabs, Callinectes sapidus. Mar. Biol. 14: 104-110.

LeRoy, N., Marie, B., Gaume, B., Guichard, N., Delgado, S., Zanella-Cleon, I., Becchi, M., Auzoux-Bordenave, S., Sire, J., and F. Marin. (2012). Identification of two carbonic anhydrases in the mantle of the European abalone Haliotis tuberculata (Gastropoda, Haliotidae): phylogenetic implications. J. Exp. Zool. 318B: 353-367.

Liao, C.M., Jau, S.F., Chen, W.Y., Lin, C.M., Jou, L.J., Liu, C.W., Liao, V.H.C. and F.J. Chang. (2008). Acute toxicity and bioaccumulation of arsenic in freshwater clam Corbicula fluminea. Enviro. Toxicol. 23: 702-711.

López Mañanes, A.A., Magnoni, L.J., and A.L. Goldemberg. (2000). Branchial carbonic anhydrase (CA) of gills of Chasmagnathus granulata (Crustacea Decapoda). Comp. Biochem. Physiol. B 127: 85-95. 
Mangum, C.P. and J. Ricci. (1989). The influence of temperature on $\mathrm{O}_{2}$ uptake and transport in the horseshoe crab Limulus polyphemus (L.). J. Exp. Mar. Biol. Ecol. 129: 243-250.

Mangum, C.P., Booth, C.E., DeFur, P.L., Heckel, N.A., Henry, R.P., Oglesby, L.C., and G. Polites. (1976). The ionic environment of hemocyanin in Limulus polyphemus. Biol. Bull. 150: 453-467.

Maren, T.H. (1967). Carbonic anhydrase in the animal kingdom. Fed. Proc. 26: 1097-1103.

Martens, W.J.M. (1998). Climate change, thermal stress and mortality changes. Soc. Sci. Med. 46: 331-344.

Markaida, U. and O. Sosa-Nishizaki. (2001). Reproductive biology of jumbo squid Dosidicus gigas in the Gulf of California, 1995-1997. Fish. Res. 54: 63-82.

Meldrum, N.U. and Roughton, F.J.W. (1933a). Carbonic anhydrase. Its preparation and properties. J. Physiol. 80: $113-142$.

Meldrum, N.U. and Roughton, F.J.W. (1933b). The state of carbon dioxide in blood. J. Physiol. 80: $143-170$.

Moazami-Goudarzi, M. and B. Colman. (2012). Changes in carbon uptake mechanisms in two green marine algae by reduced seawater pH. J. Exp. Mar. Bio. Ecol. 413: 94-99.

Moon, T.W. and A.W. Pritchard. (1970). Metabolic adapatations in verticallyseparated populations of Mytilus californianus Conrad. J. Exp. Mar. Biol. Ecol. 5: 35-46.

Morris, S. and P. Greenaway. (1990). Adaptations to a terrestrial existence by the robber crab, Birgo latro, L. v. The activity of carbonic anhydrase in gills and lungs. J.Comp. Physiol. 160: 217-221.

Nakagawa, S. and I.C. Cuthill. (2007). Effect size, confidence interval and statistical significance: a practical guide for biologists. Biol. Res.82: 591-605.

Nielsen, S.A. and E. Fierden. (1972). Some chemical and kinetic properties of oyster carbonic anhydrase. Comp. Biochem. Physiol. 41B: 875-889.

Nyack, A.C. (2013). Carbonic anhydrase activity in gills and mantle muscle from cephalopods. PhD dissertation. University of Rhode Island

Nyack, A.C., Henry, R.P. and B.A. Seibel (in prep). Characterization of carbonic anhydrase activity from squid gill and mantle tissue. 
O'Dor, R.K. (1982). Respiratory metabolism and swimming performance of the squid, Loligo opalescens. Can. J. Fish. Aquat. Sci. 39: 580-587.

O'Dor, R.K., and D.M. Webber. (1986). The constraints on cephalopods: why squid aren't fish. Can. J. Zool. 64: 1591-1605.

Osenberg, C.W., Sarnelle, O., Cooper, S.D. and R.D. Holt. (1999). Resolving ecological questions through meta-analysis: goals, metrics, and models. Ecology 80: 1105-1117.

Pavičić-Hamer, D., Devescovi, M., and Č. Lucu. (2003). Activation of carbonic anhydrase in branchial cavity tissues of lobster (Homarus gammarus) by dilute seawater exposure. J.Exp. Mar. Biol. Ecol. 287: 79-92.

Perry, S.F., Haswell, M.S., Randall, D.J., and A.P. Farrell. (1981). Branchial Ionic uptake and acid-base regulation in the rainbow trout, Salmo gairdneri. J. Exp. Biol. 92: 289-303.

Perry, S.F. (1986). Carbon dioxide excretion in fishes. Can. J. Zool. 64: 565-572.

Piller, S.C., Henry, R.P., Doeller, J.E., and D.W. Kraus. (1995). A comparison of the gill physiology of two euryhaline crab species, Callinectes sapidus and Callinectes similis: energy production, transport-related enzymes and osmoregulation as a function of acclimation salinity. J. Exp. Biol. 198: 349358.

Potts, W.T.W. (1958). The inorganic and amino acid composition in some lamellibranch muscles. J. Exp. Biol. 35: 746-764.

Preisser, E.L. and J.L. Orrock. (2012). The allometry of fear: interspecific relationships between body size and response to predation risk. Ecosphere 3: $1-27$.

Racotta, I.S., and R. Hernández-Herrera. (2000). Metabolic responses of the white shrimp, Penaeus vannamei, to ambient ammonia. Comp. Biochem. Physiol. 125A: 437-443.

Rosa, R. and B.A. Seibel. (2010). Metabolic physiology of the Humboldt squid, Dosidicus gigas: implications for vertical migration in a pronounced oxygen minimum zone. Prog. Oceano. 86: 72-80.

Rosas, C., Cuzon, G., Gaxiola, G., Le Priol, Y., Pascual, C., Rossignyol, J., Contreras, F., Sanchez, A., and A. van Wormhoudt. (2001). Metabolism and growth of juveniles of Litopenaeus vannamei: effect of salinity and dietary carbohydrate level. J. Exp. Mar. Biol. Ecol. 259: 1-22. 
Roy, L.A., Davis, D.A., Saoud, I.P., and R.P. Henry. (2007a). Effects of varying levels of aqueous potassium and magnesium on survival, growth, and respiration of the Pacific white shrimp, Litopenaeus vannamei, reared in low salinity waters. Aquaculture 262: 461-469.

Roy, L.A., Davis, D.A., Saoud, I.P., and R.P. Henry. (2007b). Branchial carbonic anhydrase activity and ninhydrin positive substances in the Pacific white shrimp, Litopenaeus vannamei, acclimated to low and high salinities. Comp. Biochem. Physiol. 147A: 404-411.

Sastry, A.N. (1979). Metabolic adaptation of Cancer irroratusi developmental stages to cyclic stages. Mar. Biol. 51: 243-250.

Sakai, K., Turkay, M., and S.L. Yang. (2006). Revision of the Helice/Chasmagnathu complex (Crustacea: Decapoda: Brachyura). Abh. Senkenb. Naturforsch. Ges. 565: 1-76.

Schmidt-Nielsen, K. (1984). Scaling: Why is Animal Size so Important? CambridgeL Cambridge University Press.

Seibel, B.A. (1998). Metabolism and locomotion of cephalopods in relation to habitat depth. PhD dissertation. University of California, Santa Barbara. 260pp.

Seibel, B.A., Thuesen, E.K., and J.J. Childress. (2000). Light-limitations on predator-prey interactions: consequences for metabolism and locomotion of deep-sea cephalopods. Biol. Bull. 198: 284-298.

Seibel, B.A., (2007). On the depth and scale of metabolic rate variation: scaling of oxygen consumption rates and enzymatic activity in the Class Cephalopoda (Mollusca). J. Exp. Biol. 210: 1-11.

Seibel, B.A., Thuesen, E.V., Childress, J.J., and L.A. Gorodezsky. (1997). Decline in pelagic cephalopod metabolism with habitat depth reflects differences in locomotory efficiency. Biol. Bull. 192: 262-278.

Seibel, B.A. and J.C. Drazen. (2007). The rate of metabolism in marine animals: environmental constraints, ecological demands and energetic opportunities. Phil. Trans. Roy. Soc. B. 362: 2061-2078.

Segawa, S. and R.T. Hanlon. (1988). Oxygen consumption and ammonia excretion rates in Octopus maya, Loligo forbesi and Lolliguncula brevis

Serrano, L., Halanych., K.M., and R.P. Henry. (2007). Salinity-mediated in expression and activity of two carbonic anhydrase isoforms in the blue crab, Callinectes sapidus. J. Exp. Bio. 210: 2320-2332. 
Serrano, L. and R.P. Henry. (2008). Differential expression and induction of two carbonic anhydrase isoforms in the gills of the euryhaline green crab, Carcinus maenas, in response to low salinity. Comp. Biochem. Phsiol. 3D: 186-193.

So, A. K-C., Espie, G.S., WIlliams, E.B., Shively, J.M., Heinhorst, H. and G.C. Cannon. (2004). A novel evolutionary lineage of carbonic anhydrase ( $\varepsilon$ class) is a component of the carboxysome shell. J. Bacteriol. 186: 623-630.

Shick, J.M., Brown, W.I., Dolliver, E.G., and S.R. Kayar. (1979). Oxygen uptake in sea anemones: effects of expansion, contraction, and exposure to air and the limitations of diffusion. Physiol,. Zool. 52: 50-62.

Siebers, D., Lucu, C., Sperling, K.R., and K. Eberlein. (1972). Kinetics of osmoregulation in the crab Carcinus maenas. Mar. Biol. 17: 291-303.

Stadie, W.C. and O'Brien, H. (1933). The catalysis of the hydration of carbon dioxide and the dehydration of carbonic acid by an enzyme isolated from red blood cells. J. Biol. Chem. 103: 521 - 529.

Stickle, W.B., Wyler, H.J., and T.H. Dietz. (2007). Effects of salinity on the juvenile crab physiology and agonistic interactions between two species of blue crabs, Callinectes sapidus and C. similis from coastal Louisiana. J. Exp. Mar. Biol. Ecol. 352: 361-370.

Taylor, E.W. and P.J. Butler. (1978). Aquatic and aerial respiration in the shore crab, Carcinus maenas (L.), acclimated to $15{ }^{\circ} \mathrm{C}$. J. Comp. Phyiol. 127: 315-323.

Taylor, E.W. and P.S. Davies. (1981). Respiration in the land crab, Gecarcinus lateralis. J. Exp. Biol. 93: 197-208.

Taylor, E.W. Butler, P.J., and A. Al-Wassia. (1977). The effects of a decrease in salinity on respiration, osmoregulation and activity in the shore crab, Carcinus maenas (L.) at different acclimation temperatures. J. Comp. Physiol. 119: 155170.

Thompson, J., and F. Melzner. (2010). Moderate seawater acidification does not elicit long-term metabolic depression in the blue mussel Mytilus edulis. Mar. Biol. 157: 2667-2676.

Tresguerres, M., Parks, S.K., Sabatini, S.E., Goss, G.G., and C.M. Luquet. (2008). egulation of ion transport by $\mathrm{pH}$ and $\left[\mathrm{HCO}_{3}^{-1}\right]$ in isolated gills of the grab eohelice (Chasmagnathus) granulata. Am. J. Physiol. 294: R1033-R1043. 
Trueblood, L.A. and B.A. Seibel. (in press). The jumbo squid, Dosidicus gigas (Ommastrephidae), living in oxygen minimum zones I: oxygen consumption rates and critical oxygen partial pressures. Deep-sea Res.II .

van Ofwegen, L. (2013). Ovabunda macrospiculata (Gohar, 1940). Accessed through: World Register of Marine Organisms at http://www.marinespecies.org/aphia.php?p=taxdetails\&id=290553

Walker, S.J., Neill, W.H., Lawrence, A.L., and D.M. Gatlin. (2009). Effect of s salinity and body weight on ecophysiological performance of the Pacific white shrimp (Litopenaeus vannamei). J. Exp. Mar. Biol. Ecol. 380: 119-124.

Walker, S.J., Neill, W.H., Lawrence, A.L., and D.M. Gatlin. (2011). Effects of temperature and starvation on ecophysiological performance of the Pacific white shrimp (Litopenaeus vannamei). Aquaculture 319: 439-445.

Webber, D.M. and R.K. O'Dor. (1985). Respiration and swimming performance in short-finned squid (Illex illecebrosus). Northwest Atl. Fish. Organ. Sci. Counc. Stud. 9: 133-138.

Weihrauch, D., Becker, W., Postel, U., Riestenpatt, S., and D. Siebers. (1998). Active excretion of ammonia across the gills of the shore crab Carcinus maenas and its relation to osmoregulatory ion uptake. J. Comp. Physiol. 168B: $364-376$.

Weis, V.M. (1991). The induction of carbonic anhydrase in the symbiotic sea anemone Aiptasia pulchella. Bio. Bull. 180: 496-504.

Weis, V.M. (1993). The induction of carbonic anhydrase in the symbiotic sea anemone Aiptasia pulchella. Biol. Bull. 180: 496-504.

Weis, V.M and W.S. Reynolds. (1999). Carbonic anhydrase expression and synthesis in the sea anemone Anthopleurael egantissima. Physiol. Biochem. Zool. 72: 307-316.

Weis, V.M., Smith, G.J., and L. Muscatine. (1989). A " $\mathrm{CO}_{2}$ supply" mechanism in zooxanthellate cnidarians: role fo carbonic anhydrase. Mar. Biol. 100: 195202.

Wells, M.J., Hanlon, R.T., Lee, P.G., and F.P. DiMarco. (1988). Respiratory and cardiac performance in Lolliguncula brevis (Cephalopoda, Myopsida): the effects of activity, temperature and hypoxia. J. Exp. Biol. 138: 17-36. 
Welsh, D.T., Dunn, R.J.K., and T. Meziane. (2009). Oxygen and nutrient dynamics of the upside down jellyfish (Cassiopea sp.) and its influence on benthic nutrient exchanges and primary production. Hydrobiologia 635: 351362 .

Wheatly, M. G., and R.P. Henry. (1987). Branchial and antennal gland $\mathrm{Na}^{+} / \mathrm{K}^{+}-$ dependent ATPase and carbonic anhydrase activity during salinity acclimation of the euryhaline crayfish Pacifastacus leniusculus. J. Exp. Biol. 133: 73-86.

Wheatly, M.G. (1989). Standard rate of $\mathrm{O}_{2}$ uptake and body size in the crayfish Pacifasticus lenisculus (Dana, 1952) (Decapoda: Astacidae): intra- versus interspecific relations in crustaceans. J. Crust. Biol. 9: 212-216.

Widdows, J. and J.M. Shick. (1985). Physiological response of Mytilus edulis and Cardium edule to aerial exposure. Mar. Biol. 85: 217-232.

Wright, P.A., Randall, D.J., and S.F. Perry. (1989). Fish gill boundary layer: a site of linkage between carbon dioxide excretion and ammonia excretion. J. Comp. Physiol. 158B: 627-635.

Yellowlees, D., Dionisio-Sese, M.L., Masuda, K., Maruyama, T., Abe, T., Baillie, B., Tsuzuki, M. and S. Miyachi. (1993). Role of carbonic anhydrase in the supply of inorganic carbon to the giant clam-zooxanthellate symbiosis. Mar. Biol. 115: 605-611.

Zhang, L., Shen, Q., Hu, H., Shao, S., and C Fan. (2011). Impacts of Corbicula fluminea on oxygen uptake and nutrient fluxes across the sediment-water interface. Water Air Soil Pollut. 220: 399-411.

Zhang, L., Liao, Q., He., W., Shang, J., and C. Fan. (2013). The effects of temperature on oxygen uptake and nutrient flux in sediment inhabited by molluscs. J. Limnol. 72: 13-20. 